Florida International University FIU Digital Commons

3-20-1997

\title{
Biology and use of nibbi heteropsis flexuosa (ARACEAE) the source of an aerial root fiber product in Guyana
}

Bruce Hoffman

Florida International University

DOI: $10.25148 /$ etd.FI15101911

Follow this and additional works at: https://digitalcommons.fiu.edu/etd

Part of the Biology Commons

\section{Recommended Citation}

Hoffman, Bruce, "Biology and use of nibbi heteropsis flexuosa (ARACEAE) the source of an aerial root fiber product in Guyana" (1997). FIU Electronic Theses and Dissertations. 2716.

https://digitalcommons.fiu.edu/etd/2716 


\section{FLORIDA INTERNATIONAL UNIVERSITY}

Miami, Florida

BIOLOGY AND USE OF NIBBI HETEROPSIS FLEXUOSA (ARACEAE):

THE SOURCE OF AN AERIAL ROOT FIBER PRODUCT IN GUYANA

A thesis submitted in partial satisfaction of the

requirements for the degree of

MASTER OF SCIENCE

IN

BIOLOGICAL SCIENCES

by

Bruce Hoffman

1997 
To: Arthur W. Herriott

College of Arts and Sciences

This thesis, written by Bruce Hoffman, and entitled "Biology and use of Nibbi Heteropsis flexuosa (Araceae): the source of an aerial root fiber product in Guyana", having been approved in respect to style and intellectual content, is referred to you for judgment.

We have read this thesis and recommend that it be approved.

Dr. Jack F. Fisher

Dr. David W. Lee

Dr. Bradley C. Bennett, Major Advisor

Date of Defense: March 20, 1997

The thesis of Bruce Hoffman is approved.

Dean Arthur W. Herriott

College $p \mathrm{f}$ Arts and Sciences

Dean Richard L. Campbell

Division of Graduate Studies

Florida International University, 1997 


\section{ACKNOWLEDGMENTS}

I would like to first thank the people of Manawarin, Karupukari, and Surama villages for their hospitality, friendliness, and invaluable assistance in the field. In particular, I am indebted to James Miguel, Irwin Miguel, Gilbert Adams, and Daniel Allicock. It was indigenous people who first recognized the useful properties of nibbi. The nibbi furniture industry and my research owe much to this original discovery.

In addition, I would like to thank several organizations and people in Georgetown, Guyana for their assistance. Jocelyn Dow of Red Thread and Frank Alfonso of Liana Cane Interiors helped me in within-country travel and with learning about the nibbi market in Georgetown. Also, Henry Tschenkel and his staff at Iwokrama International Rainforest Reserve were encouraging and provided me with transportation, food and lodging at the field station near Karupukari. In addition, the Biological Diversity of the Guianas program of the Smithsonian Institution has assisted my research in many ways, including international airfare, housing and research facilities in Georgetown, and field supplies.

I am grateful to my major advisor Dr. Bradley Bennett and committee member Dr. David Lee at Florida International University for their encouragement and support. I also thank Dr. Jack Fisher at the Fairchild Tropical Garden research center who served on the committee and assisted me with anatomical studies in his laboratory. In addition, Dr. Tom Croat at the Missouri Botanical Garden graciously provided determinations for plant specimens. I was supported by the Garden Club of Allegheny County in Pittsburgh, Pennsylvania with substantial funding and inspiration.

Lastly, but not least, I express gratitude to Christiane Ehringhaus and to my family for support and encouragement throughout the research and writing of this thesis. 


\title{
ABSTRACT OF THE THESIS
}

Biology and use of Nibbi Heteropsis flexuosa (Araceae): the source of an aerial root fiber product in Guyana

\author{
by \\ Bruce Hoffman \\ Florida International University, 1997 \\ Miami, Florida
}

Dr. Bradley C. Bennett, Major Professor

The aerial roots of Heteropsis flexuosa (Kunth) Bunting, a hemi-epiphyte, are harvested by indigenous communities in Guyana for a developing wicker furniture market. Nibbi roots have potential as a sustainably harvested product, but there is little data to guide management. I examined nibbi biology, harvest response, product yield and use at several forest sites. $H$. flexuosa is a relatively abundant plant and $35 \%$ of trees $(\geq 10 \mathrm{~cm} \mathrm{dbh})$ in plots were hosts. Stems exhibited mean growth rates of $1-3 \mathrm{~cm}$ per month. Aerial roots grew a mean $156 \mathrm{~cm}$ per month and some reached maturity within 6 months. With present methods, harvest does not decimate populations because $97 \%$ of colonized trees possess few harvestable roots. But, only $28 \%$ of cut roots re-generated in experiments. For indigenous harvesters at Manawarin village, nibbi harvesting is a primary source of cash income and is important in daily subsistence. 


\section{TABLE OF CONTENTS}

Acknowledgements

Abstract

Table of Contents

List of Figures and Tables

I. INTRODUCTION AND BACKGROUND

1.1 THE Study Plant: Heteropsis Flexuosa (KLNTH)BUNTING 6

$\begin{array}{ll}1.2 \text { PHYSICAL GEOGRAPHY } & 23\end{array}$

1.3 HUMAN GEOGRAPHY

II. NATURAL DISTRIBUTION, GROWTH AND ROOT ANATOMY OF NIBBI

2.1 INTRODUCTION $\quad 47$

2.2 MATERIALS AND METHODS $\quad 48$

2.3 RESULTS AND DISCUSSION $\quad 58$

$\begin{array}{lr}2.4 \text { CONCLUSIONS } & 81\end{array}$

III. IMPACT OF AERIAL ROOT HARVEST ON NIBBI

3.1 INTRODUCTION

3.2 MATERIALS AND METHODS

3.3 RESULTS AND DISCUSSION

$\begin{array}{lr}\text { A. HARVEST INTENSITY } & 89\end{array}$

B. HARVEST IMPACT $\quad 90$

$\begin{array}{ll}3.4 \text { CONCLUSIONS } & 97\end{array}$

IV. ECONOMICS OF NIBBI

$\begin{array}{ll}\text { 4.1 INTRODUCTION } & 100\end{array}$

4.2 MATERIALS AND METHODS 101

4.3 RESULTS AND DISCUSSION

A) YIELD 106

B) VALUE $\quad 110$

C) IMPORTANCE $\quad 114$

D) MARKET STRUCTURE $\quad 116$

$\begin{array}{ll}4.4 \text { CONCLUSIONS } & 123\end{array}$

V. CONCLUSIONS AND RECOMMENDATIONS 125

VI. LITERATURE CITED $\quad 131$

$\begin{array}{lr}\text { VII. APPENDICES } & 140\end{array}$ 


\section{LIST OF FIGURES}

$\begin{array}{lll}\text { Figure 1.1 Stem growth habit and size classes of } H . \text { flexuosa } & 11\end{array}$

Figure $1.2 \quad$ Fertile plagiotropic branches of $H$. flexuosa and H. spruceana 12

Figure 1.3 Aerial root growth habit of $H$. flexuosa 13

$\begin{array}{lll}\text { Figure 1.4 Map of Guyana } & 24\end{array}$

Figure 1.5 Map of Manawarin and Pomeroon River Region 25

Figure 1.6 Map of Iwokrama International Rainforest Reserve 26

Figure 1.7 Map of major landscape types in Guyana 30

$\begin{array}{lll}\text { Figure } 1.8 & \text { Climate diagram of Great Falls } & 30\end{array}$

$\begin{array}{lll}\text { Figure } 1.9 & \text { Photograph of nibbi harvester pulling root } & 37\end{array}$

Figure 1.10 Photograph of unrolled bundle of nibbi 38

Figure 1.11 Photograph of nibbi root cortex removal 39

Figure 1.12 Photograph of nibbi bundles at market 40

Figure 1.13 Photograph of nibbi root being split length-wise 41

Figure 1.14 Photograph of basketry work with nibbi 42

Figure 1.15 Photograph of nibbi chair assembly in Georgetown 43

$\begin{array}{lll}\text { Figure 2.1 Diagram of host tree zonation } & 52\end{array}$

Figure 2.2 Absorbing root transverse-section of $H$. flexuosa

$\begin{array}{lll}\text { Figure 2.3 Close-up absorbing root transverse-section } & 73\end{array}$

$\begin{array}{lll}\text { Figure } 2.4 \quad \text { Drawing of macerated fibers } & 74\end{array}$

$\begin{array}{lll}\text { Figure } 4.1 \quad \text { Nibbi root product use categories } & 103\end{array}$

$\begin{array}{lll}\text { Figure 4.2 Nibbi furniture market structure and pricing chart } & 121\end{array}$ 


\section{LIST OF TABLES}

Table 2.1 No. plots in habitats at Iwokrama and Manawarin research areas 50

Table 2.2 Parameters for qualitative data 50

Table 2.3 No. colonized trees $\geq 10 \mathrm{~cm}$ dbh per 0.1 ha arranged by habitat 62 and site

Table 2.4 Association of $H$. flexuos $a$ with light intensity and vertical host 62 zones

Table 2.5 Association of $H$. flexuos $a$ with climbing plants and host dbh 63

Table 2.6 Growth, survival, and mortality of $H$. flexuosa stems and roots. 63

Table 2.7 Size of fibers obtained from four distinct cross-sectional zones $\quad 77$ within a mature $H$. flexuosa absorbing root

Table 3.1 No. trunk and drop roots per host tree arranged by habitat 91 and site

Table $3.2 \quad$ Frequency distribution of $H$. flexuosa trunk and drop roots on 91 host trees

Table 3.3 Size-class distribution and root abundance of $H$. flexuosa in 92 harvested and unharvested plots at the Manawarin study site

Table $3.4 \quad$ Response of $H$. flexuosa stems and roots to root harvest 95

Table $3.5 \quad$ Correlation of percent roots cut with $H$. flexuosa stem and 95

Table 4.1 Product yield from $H$. flexuosa absorbing roots per 0.1 ha $\quad 109$ arranged by habitat and site

Table 4.2 Distribution of furniture root internodes and value per 1.0 ha arranged by habitat and site. 


\section{CHAPTER I. INTRODUCTION AND BACKGROUND}

Tropical forests provide forest people with substantial material wealth, including food, medicine, shelter, technology, and market items (Bennett 1992a, Duke 1992, Prance et. al. 1987). Although some historical uses of the forest may have been unsustainable, generations of pre-industrial cultures have derived benefits without destroying their resource base. Since World War II, however, population growth, coupled with socioeconomic inequities (especially in land distribution), have resulted in over-exploitation of tropical forest wealth and unbridled deforestation in many countries (Anderson 1990, Hecht and Cockburn 1989, Schmink 1987).

Deforestation has been a prominent and controversial topic throughout the 1980's and 1990's, with proponents of economic growth and conservation pitted against one another and shifting cultivators often portrayed as the villains (Caufield 1984). Concurrently with popularization of the biotic and human impovisherment resulting from deforestation (Myers 1984, Woodwell 1990), researchers in various disciplines have presented new models for sustainable use of tropical forests (Anderson 1990, FAO 1995, Famolare and Plotkin 1992, Gómez-Pompa and Burley 1992, Nepsted and Schwartzman 1992, Panayotou and Ashton 1992a, Schmink et. al. 1992). Most of these studies are based on the assumption that, as long as market forces drive resource use, realistic solutions to deforestation and poverty must link conservation and development. As stated succinctly 
by Nepsted and Schwartzman (1992), "Can tropical forests generate revenue without being cut down? If so, for whom?".

Harvest of non-timber forest products (NTFP's) has been advanced as one of the more promising forest uses that could provide economic benefits at local, regional, and national levels while encouraging conservation (Panayotou and Ashton 1992b, Peters et. al. 1989). The impact on forest ecosystems from NTFP harvest (specifically non-wood products) is minimal compared to large-scale logging, ranching, and agriculture (Nepsted 1992). In addition, NTFP's generally have shorter harvest cycles than timber species, many providing products annually over long periods (Peters and Hammond 1990). Also, the harvest of local NTFP's encourages the maintenance of indigenous culture because individuals can participate in the cash economy without leaving their communities (Forte 1996a). Although they are traditionally classified as "minor forest products" by governments and industry, non-timber products generate substantial income in many countries and are important to rural households for non-market uses (Ave 1988, de Beer and McDermott 1989, Padoch 1987).

Despite the documented benefits, there are many unresolved questions, difficulties, and untested assumptions about the increased harvest and marketing of NTFP's (Godoy and Bawa 1993, Browder 1992). In terms of ecological sustainability, few studies have quantified the extraction rates, impact of harvest, and growth rate of harvested populations (for exceptions see Cunningham 1987, Frankie 1994, Peters and Hammond 
1990, Shankar et. al. 1996, Sullivan et. al. 1995). In addition, the economic history of commercial NTFP extraction is characterized by unpredictability and "boom and bust" patterns (Homma 1992). Most NTFP's are harvested with a low yield, uneven product flow, highly variable quality, low prices, and high transportation costs. Products that become valuable tend to be overharvested and then substituted by other products or grown in plantations. Loss in value may also result in overexploitation as collectors attempt to maintain their income level through increased harvest. In addition, economic incentives alone do not guarantee benefits to rural populations and do not guarantee forest conservation (Padoch 1992). The history of NTFP extraction is characterized by social inequities such as debt-peonage and lack of land tenure.

In seeking answers to the potential short-comings of NTFP extraction, researchers have recommended formation of grassroots, co-operative marketing organizations; increasing the value of products locally; securing land tenure; and diversifying the market base as much as possible (Browder 1992, Clay 1992). In addition, scientific research and documentation of forest people's knowledge on ecological sustainability is important (Schmink et. al. 1992). The complex of conditions (local, regional, national, ecological, market, socio-political) characterizing each specific situation must be carefully examined. In particular, local communities need to be consulted to document their needs, aspirations, and acceptance of NTFP harvesting. Commercial harvest of NTFPs may be appropriate in some situations and not in others. Sustainable and profitable use of non-timber forest resources requires the interaction of harvesting communities, researchers, governments, 
industry, and non-governmental organizations in forming an overall land use and development strategy (FAO 1995, Ros-Tonen et. al. 1995).

For approximately fifty years, certain indigenous communities in Guyana have harvested the roots of Heteropsis flexuosa (Kunth) Bunting for a small-scale handicraft and wicker furniture market. Heteropsis species are forest-dwelling climbers that produce long, tough aerial roots. In recent years, harvest intensity has increased due to growth in exportoriented furniture production in Guyana. Nibbi has potential as an ecologically sustainable NTFP because roots can be removed without killing plants and because harvest is minimally damaging to forest structure. In addition, the commercial potential of nibbi is strong because it is already a well-established product and a relatively abundant plant in lowland forests. World trade in rattan products generates approximately US $\$ 3$ billion annually and employs over 500,000 people in collecting, processing, and manufacturing in SE Asia (DeBeer and McDermott, 1989). If nibbi furniture export could substitute for even a small percentage of rattan in overseas markets, substantial revenue could be generated for Guyana's small population

I initiated my research because the potential role of the nibbi furniture industry in sustainable development had received little attention and there was little scientific data on H. flexuosa. My objective was to provide baseline biological data and to examine the potential and the limitations of $H$. flexuosa as a viable rain forest product in Guyana. 
Specifically, my research questions were:

\section{Biology and Ecology}

How abundant are nibbi plants and where do they grow? What are defining structural and growth characteristics of nibbi plants?

\section{Harvest and Sustainability}

How is nibbi harvested and what is the impact of harvest? What is the potential for sustained-yield harvest?

\section{Economics and Local Importance}

What is the yield, value, local importance, and market structure of nibbi root product? 


\subsection{StUdy Plant: Heteropsis FleXuosa (KUNTH) BUnting}

Heteropsis is a small neotropical genus in the Araceae with 12-13 species (Appendix I). Species range from the Brazilian Amazon and Bolivia as far north as Nicaragua, with a center of diversity in southeastern Venezuela and the Guianas. Populations are found in a variety of forest types from 30 to 1000 meters elevation, including highland massifs and lowlands. Vernacular names for Heteropsis species include cipó titica (Portuguese/Brazil, Medina 1959), ue yai or po'po (Siona-Secoya/Ecuador, Paz y Miño et. al. 1995), mamure (Spanish/Venezuela, Romero 1993), kaap (Shuar, Ecuador; Bennett, pers. comm.), nibbi or mibi (Carib/Guyana; Fanshawe 1950), piquihua (Chachi, Ecuador; Bennett, pers. comm.), sarabanaroo (Arawak/Guyana, Fanshawe 1950), tamshi (Spanish/Peru, MacBride 1936), tedbai (Miraña/Colombia, La Rota et. al 1987) and tun (Tukuna/Colombia, Glenboski 1983).

Heteropsis is surprisingly little studied by botanists and ethnobotanists. Beyond descriptions in floristic works, there are occasional accounts of Heteropsis species in ethnobotanical inventories (e.g., Oliveira et. al. 1991), ethnobotanical plot studies (e.g., Salick 1992), 19th century travel narratives (e.g., Im Thurn 1883) and anatomical works (e.g., French 1987b). Romero (1993) conducted quantitative biological and harvest research on Heteropsis spruceana Schott at a 0.25 ha site in Venezuela. His research and the present thesis are the only known studies to focus specifically on a Heteropsis species 


\section{A) TAXONOMIC HISTORY AND CLASSIFICATION}

The systematic history of Heteropsis was reviewed by Romero (1993), and I use portions of his report in the next few pages. The genus was first described by $\mathrm{C}$. S. Kunth (1841) based on two species, $H$. oblongifolia and $H$. salicifolia, collected in Brazil. Additional species descriptions and the first overview of the genus were provided by $\mathrm{H}$. W. Schott in Aroideae (1853) and Prodomus Systematis Aroidearum (1860). Engler later published monographs of the three known Heteropsis species (H. oblongifolia, $H$. salicifolia, and H. spruceana) in Monographiae Phanerogamarum (1879) and lists three additional species ( $H$. rigidifolia, $H$. longispathacea, $H$. jenmanii) in the serial Das Pflanzenreich $(1905,1920)$. Since Engler's monographs, the genus has been described in floristic works, checklists, and field guides (Brako and Zarucchi 1993; Bunting 1979, 1986, 1988, 1996; Dodson and Gentry 1978; Funk et. al. 1993; Gentry 1993; MacBryde 1936; Smith 1939; Standley 1937) but there have been no new revisions or monographs. In addition, there is no comprehensive generic key available. Heteropsis species are listed in Appendix I.

Humboldt, Bonpland, and Kunth were the first to describe nibbi (from a Venezuelan specimen), in Nova General et Species Plantarum (1825), naming it Pothos flexuosus. In 1890, nibbi was described as a new species, Heteropsis jenmanii Oliver, in Hooker's Icones Plantarum (1890). The holotype was collected by G. S. Jenman in Guyana (Mazaruni River, Kalacoon, Jenman 5000). In Bunting (1979), nibbi was given the presently accepted name of Heteropsis flexuosa (Kunth) Bunting. 
The systematics of the Araceae family have traditionally fallen within two general schools, that of Engler and that of Schott. Engler's system weighs vegetative characters more heavily and Schott's system is florally based. Specialists agree in placing the genus Heteropsis within the Pothoideae subfamily of the aroids (Grayum 1990). There is not complete agreement, though, on the definition of the subfamily and the assignment of tribes. Madison (1975 and 1977) follows Engler in defining a distinct Heteropsideae tribe for Heteropsis based on subsessile leaves, geniculum presence, trichlosclereid absence, and monopodial habit. Grayum (1990) cites intermediate character states for Heteropsis with floral structure and pollen similar to Monstereae and monopodial growth and trichlosclerid absence as found in Pothoideae. He joins the two subfamilies under the title of Pothoideae and places Heteropsis within the tribe Monstereae and monogeneric subtribe Heteropsinidae. Other neotropical genera in the Monstereae as defined by Grayum include Monstera, Stenospermation, and Rhodospatha.

\section{B) MORPHOLOGICAL DESCRIPTION AND NATURAL HISTORY}

The following morphological and life history description is based on my field observations of Heteropsis flexuosa (Kunth) Bunting in Guyana. The generalized growth habit described is applicable to the majority of Heteropsis species, based on a review of herbarium specimens (Appendix II) and of literature (see floristic works cited above). At least one species, Heteropsis melinonii (Engl.) Fonker, Verhoef \& Fonker, lacks strong, woody aerial roots. 


\section{THE HEMI-EPIPHYTIC HABIT}

Heteropsis species are viney root-climbers that generally grow in mature forests, although there are a few reports of their occurrence in secondary forests (Glenboski 1983). Plants germinate terrestrially, climb tree trunks, and establish mature (ie. sexually reproductive), plagiotropic branches at various heights. As Heteropsis individuals climb, the lower stem and original roots decompose, but a ground connection is re-established through the growth of absorbing roots (Figure 1.1).

There are at least 5 potential epiphyte classification schemes (Benzing 1983). Criteria include: 1) relationship of the epiphyte to its host plant; 2) growth habit; 3) climatic tolerance; 4) substrate preference; and 5) mechanisms for procuring resources. Using the "relationship of the epiphyte to its host plant" scheme, plants that are epiphytic at some point in their life history and become secondarily connected with the ground are collectively termed hemi-epiphytes (Schimper 1903, Richairds 1952, Putz and Holbrook 1986).

Within the hemi-epiphytic classification, there are two distinct growth habits. Taxa such as Heteropsis that germinate terrestrially and climb upwards are secondary hemi-epiphytes (Putz and Holbrook 1986; also pseudo-epiphytes of Schimper 1903 and hemi-epiphyta postera of Hosokawa 1949). Secondary hemi-epiphytes occur only in the Araceae, Marcgraviaceae, and Cyclanthaceae (Putz 1986). In contrast, taxa that germinate as 
epiphytes and later become rooted in the soil, such as Chusia and Ficus, are recognized as primary hemi-epiphytes (e.g. Daniels 1991, Putz 1986, Todzia 1986; also hemi-epiphytes of Schimper 1903; hemiepiphyta praecoqua of Hosokawa 1949). Primary hemi-epiphytes occur in at least 20 dicot plant families (Putz 1986).

\section{MATURE CLUSTERS}

Heteropsis species are one of only four genera in the Araceae that retain monopodial shoot growth throughout their life history (Grayum 1990, p. 636). "Mature clusters" (defined by author) are points along a monopodial, climbing Heteropsis stem where several to many plagiotropic (horizontally-oriented), leafy branches are issued (Fig. 1.1). Terminal inflorescences are also eventually borne at these sites, on determinant side shoots (Fig. 1.2). An individual stem may produce many mature clusters at different heights on the host. In addition, the mature clusters of different stems are often intermixed on host trees, producing large shrubby masses on upper tree trunks. I rarely observed $H$. flexuosa stems growing above the lower host canopy branches.

In $H$. flexuosa, the plagiotropic branches of mature clusters are robust (up to $1 \mathrm{~cm}$ diameter), with short internodes ( $1-8 \mathrm{~cm}$ length), and extend out horizontally up to 1.5 meters. Branch leaves are coriaceous with very fine parallel veins, distichous, alternately arranged, elliptic or oblong (occasionally obovate) in outline, and with mucronate apices. Leaf dimensions are 10 to $20 \mathrm{~cm}$ in length and 6 to $8 \mathrm{~cm}$ in width. 


\section{THE HEMI-EPIPHYTIC HABIT}

Heteropsis species are viney root-climbers that generally grow in mature forests, although there are a few reports of their occurrence in secondary forests (Glenboski 1983). Plants germinate terrestrially, climb tree trunks, and establish mature (ie. sexually reproductive), plagiotropic branches at various heights. As Heteropsis individuals climb, the lower stem and original roots decompose, but a ground connection is re-established through the growth of absorbing roots (Figure 1.1).

There are at least 5 potential epiphyte classification schemes (Benzing 1983). Criteria include: 1) relationship of the epiphyte to its host plant; 2) growth habit; 3) climatic tolerance; 4) substrate preference; and 5) mechanisms for procuring resources. Using the "relationship of the epiphyte to its host plant" scheme, plants that are epiphytic at some point in their life history and become secondarily connected with the ground are collectively termed hemi-epiphytes (Schimper 1903, Richards 1952, Putz and Holbrook 1986).

Within the hemi-epiphytic classification, there are two distinct growth habits. Taxa such as Heteropsis that germinate terrestrially and climb upwards are secondary hemi-epiphytes (Putz and Holbrook 1986; also pseudo-epiphytes of Schimper 1903 and hemi-epiphyta postera of Hosokawa 1949). Secondary hemi-epiphytes occur only in the Araceae, Marcgraviaceae, and Cyclanthaceae (Putz 1986). In contrast, taxa that germinate as 
epiphytes and later become rooted in the soil, such as Chusia and Ficus, are recognized as primary hemi-epiphytes (e.g. Daniels 1991, Putz 1986, Todzia 1986; also hemi-epiphytes of Schimper 1903; hemiepiphyta praecoqua of Hosokawa 1949). Primary hemi-epiphytes occur in at least 20 dicot plant families (Putz 1986).

\section{MATURE CLUSTERS}

Heteropsis species are one of only four genera in the Araceae that retain monopodial shoot growth throughout their life history (Grayum 1990, p. 636). "Mature clusters" (defined by author) are points along a monopodial, climbing Heteropsis stem where several to many plagiotropic (horizontally-oriented), leafy branches are issued (Fig. 1.1). Terminal inflorescences are also eventually borne at these sites, on determinant side shoots (Fig. 1.2). An individual stem may produce many mature clusters at different heights on the host. In addition, the mature clusters of different stems are often intermixed on host trees, producing large shrubby masses on upper tree trunks. I rarely observed $H$. flexuosa stems growing above the lower host canopy branches.

In H. flexuosa, the plagiotropic branches of mature clusters are robust (up to $1 \mathrm{~cm}$ diameter), with short internodes ( $1-8 \mathrm{~cm}$ length), and extend out horizontally up to 1.5 meters. Branch leaves are coriaceous with very fine parallel veins, distichous, alternately arranged, elliptic or oblong (occasionally obovate) in outline, and with mucronate apices Leaf dimensions are 10 to $20 \mathrm{~cm}$ in length and 6 to $8 \mathrm{~cm}$ in width. 
A.

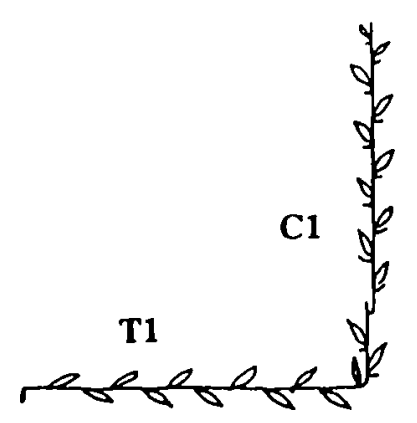

B.

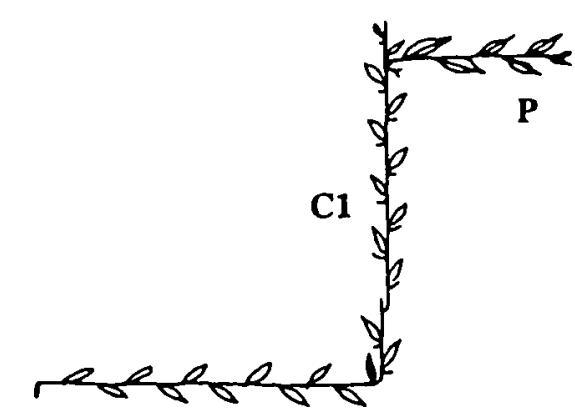

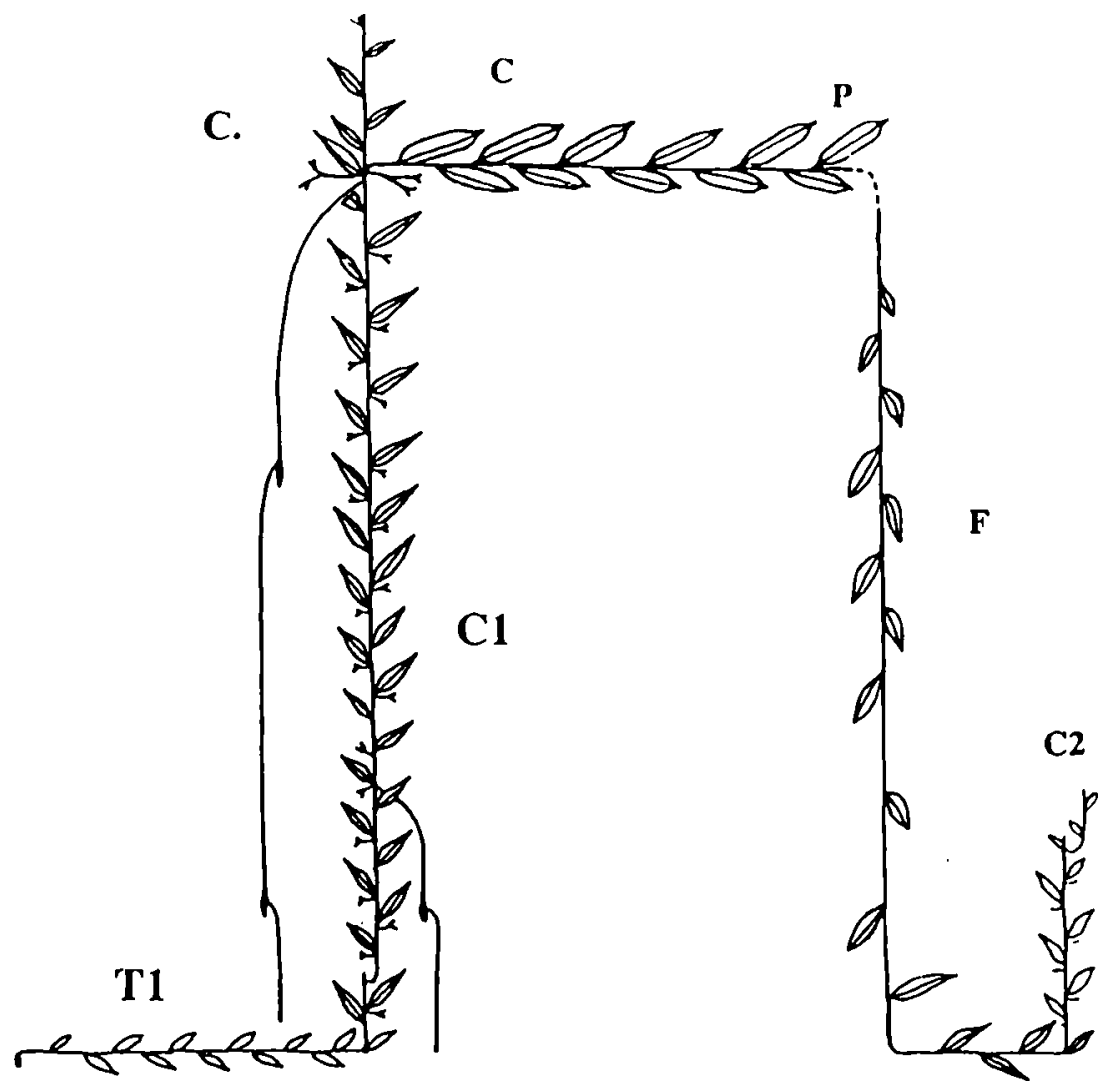

Figure 1.1 Stem growth habit and size classes of Heteropsis flexuosa (schematic without visible host tree): A) seedling; B) juvenile; C) mature cluster; T1) flagellar seedling shoot; C1) climbing shoot; P) plagiotropic branch; F) flagellar shoot; 2 ) secondary juvenile. 


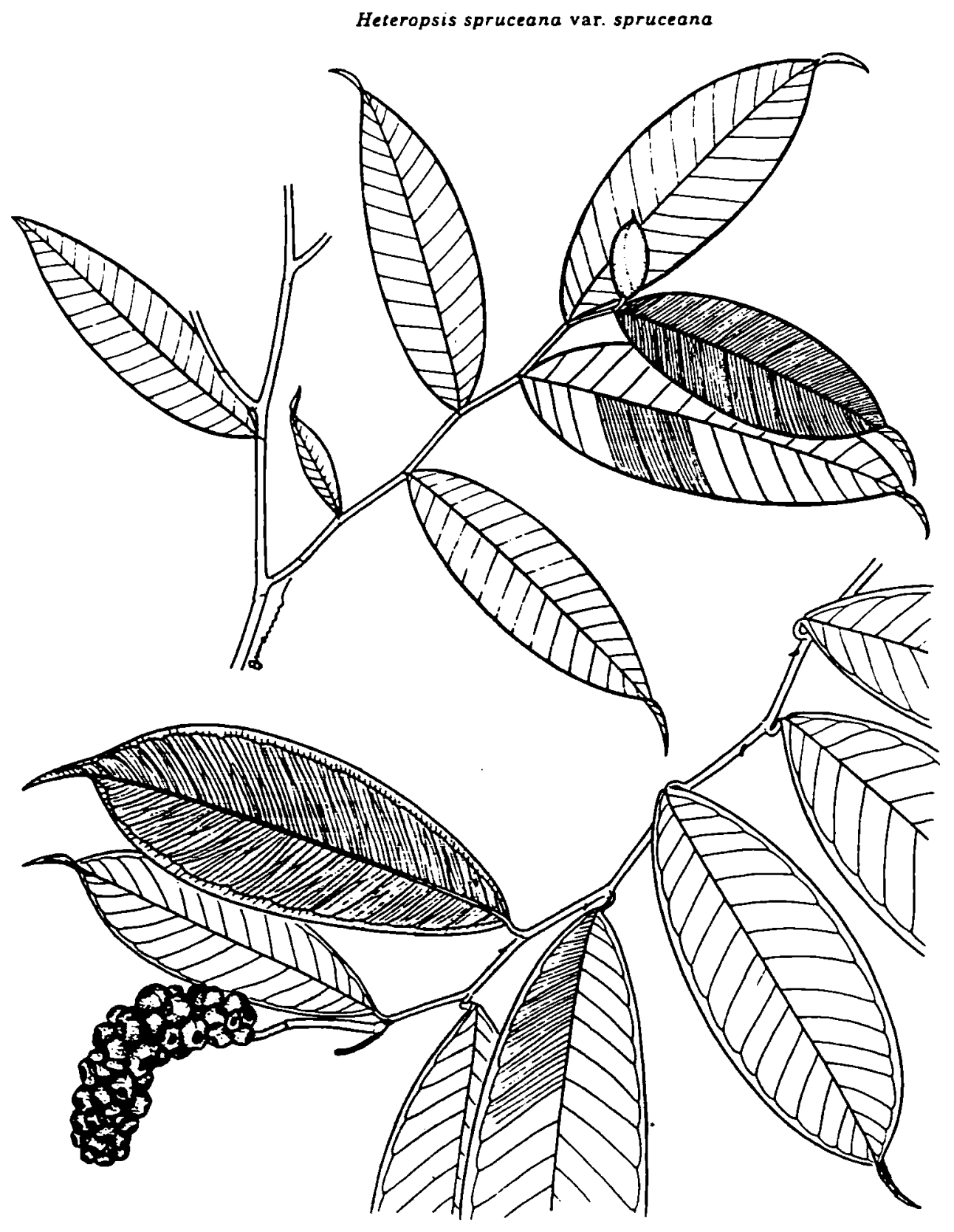

Heteropsis flexuosa var. flexuosa

Figure 1.2 Fertile plagiotropic branches of Heteropsis flexuosa (Kunth) Bunting and Heteropsis spruceana Schott (after Bunting 1996). 


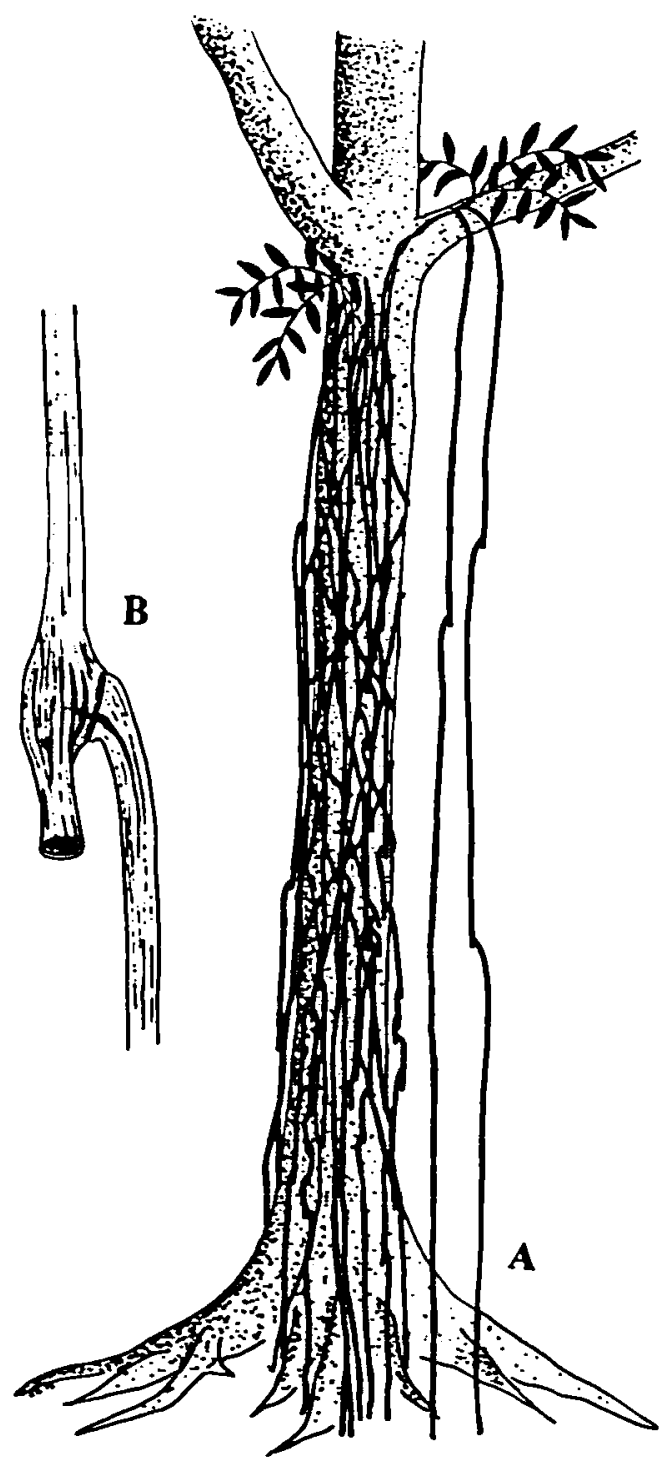

Figure 1.3 Aerial root growth habit of $H$. flexuosa: A) absorbing trunk roots and absorbing drop roots; B) absorbing root "node". 


\section{PLASTIC VEGETATIVE GROWTH: FLAGELLAR SHOOTS AND CLIMBING SHOOTS}

As with many other root-climbers in the Araceae, Heteropsis exhibits highly plastic vegetative growth (Fig. 1.1). Vegetative plasticity is common in monocots due to their modular structure (Benzing 1983, p. 303), but the trait is extreme in the root-climbing aroids. Shoot meristems can shift back and forth between developmental pathways, allowing for rapid structural changes (internode width, length, and leaf size) in response to newly encountered microhabitats (Ray 1987, 1988, 1990b, 1992). A stem growth-form continuum was recognized in the Araceae by Ray (1992), ranging from sessile mature forms with large leaves, large stem diameters and short internodes to mobile forms with reduced leaves (often cataphylls), small stem diameters, and long internodes.

In Heteropsis flexuosa, two of the shoot developmental pathways recognized by Ray (1992) occur: the mobile flagellar shoot and the less mobile climbing creeping shoot. Flagellar shoots have stems at least thirty times as long as wide and reduced lanceolate leaves or cataphylls. This structure allows for efficient, minimal resource use and rapid movement. Ray (1992) views flagellar shoots as "elongating umbilical cords for the dispersal of apical meristems".

At field sites, I observed $H$. flexuosa flagellar shoots descending from mature clusters in host trees, growing away from mature stems on fallen host trees, and descending from overtopped low trees and shrubs. Once on the ground, flagellar shoots grow scandently and climb the same or another host tree. In one rare case, a flagellar shoot colonized a 
new host by moving horizontally across the branches between two trees, i.e., without soil contact. Initiation of flagellar shoot development pattern may result from loss of contact with the substrate (Ray 1992), inadequate climactic conditions, or insufficient nutrient gain. It is also possible that flagellar growth is initiated in those resource-rich stems that can afford to inititate vegetative expansion. In flagellar stems originating from older stems I did not observe skototropic (towards dark) growth (Strong and Ray 1975).

Young seedlings develop flagellar shoots with long, achlorophyllous internodes and cataphylls. I observed many seedlings growing directly towards adjacent trees, detecting potential hosts skototropically. In addition, I observed the apical meristem of most seedlings raised slightly above the forest floor, possibly to facilitate skototropic host detection.

Once flagellar shoots contact host trees, the shoot developmental pattern switches to the climbing/creeping form with shorter internodes and larger leaves. Older H. flexuosa climbing stems have internode lengths of $5-10 \mathrm{~cm}$, internode widths of $0.3-0.7 \mathrm{~cm}$, and lanceolate to elliptic leaves of $7-12 \mathrm{~cm}$ in length. Juvenile $H$. flexuosa stems have internode lengths of $1-5 \mathrm{~cm}$, internode widths of $0.1-0.2 \mathrm{~cm}$, and lanceolate leaves of 3 $-7 \mathrm{~cm}$ in length. Climbing stems grow up the face of the host trunk with anchoring roots (see root section below). Depending on host suitability and unknown environmental requirements, the climbing stem establishes mature clusters, grows slowly without establishing mature clusters, or initiates a flagellar shoot to search for a new host. The 
internodes and leaves of the different shoot forms are very distinct but do not exhibit the extreme heterophylly documented for some aroids (Grayum 1990, Madison 1977, Ray 1981).

Due to vegetative plasticity, it is virtually impossible to distinguish $H$. flexuosa genets in the field. Non-seedling flagellar shoots often colonize new host trees as ramets. Once the lower stem of a flagellar ramet decomposes there is no evidence linking it to a mother stem. Some apparent $H$. flexuosa populations in the forest are probably a single clone. In addition, it is even difficult to distinguish between ramets in the field, because $H$. flexuosa plants often grow as large bushy masses with many stems on a given host tree.

\section{VEGETATIVE GROWTH: ROOTS}

Heteropsis exhibits two different types of roots, referred to here (after Wilder 1992) as anchoring and absorbing roots (Fig. 1.3). This state of "heterorhizy" (Raju et. al. 1963) is particularly prevalent in Araceae and Cyclanthaceae and was first described in 1838 by Poeppig and Enlicher for Thoracocarpus bissectus [Cyclanthaceae] (cited by Wilder 1992). Anatomical studies that distinguish between absorbing and anchoring roots in various taxa (not including Heteropsis) include Harling (1958), Porsch (1931), Schimper (1884, 1888, 1903), Troll (1943), Went (1895), and Wilder (1977ab, 1988, 1991, 1992).

In Heteropsis, anchoring and absorbing roots emerge adventitiously from aerial stems. As with other epiphytic aroid species described by Went (1895), H. flexuosa anchoring roots 
emerge only from the "inner side" of the stem held against the host tree while absorbing roots emerge from the "outer side" of the stem. Anchoring roots grow laterally across the host surface, eventually encircling the host tree, but I saw no instances of host strangling. In comparison to absorbing roots, anchoring roots are smaller in diameter, have narrower xylem elements, and much less vascular tissue (Wilder 1992). Absorbing roots grow immediately downwards and eventually enter the soil, becoming simultaneously aerial and subterranean. The young growing absorbing roots of $H$. flexuosa are very soft and dark brown in color. Mature roots are tough, flexible, dense, and brownish-grey in color, having the appearance and feel of smooth wood. The presence of large amounts of vascular tissue and wide xylem elements supports the view of Schimper $(1884,1888$, 1903) and others that absorbing roots function primarily in transport of water and nutrients.

As emergent absorbing roots grow towards the soil, they either spiral loosely around the host trunk or grow straight down through the air. For this study, I define those absorbing roots that grow straight down as drop roots and those that spiral around as trunk roots (Fig. 1.3). The two growth types result from differences in position on the host. Roots that emerge from stems located on strongly leaning trees or on branches away from the host trunk will grow straight down and those in close proximity to the host trunk will wrap around. 
Heteropsis absorbing root meristems are often injured through herbivory (Romero 1993, Hoffman, pers. obs.) or mechanical damage. In response, a lateral replacement root (Wilder 1991) emerges from the pericycle above the damaged area (Fig. 1.3). Thus, what appears as a single Heteropsis root is a series of linked root segments, a sympodium. Where adventitious lateral roots emerge, tissues bulge to form dense swollen structures. I refer to these structures as "nodes" and the root lengths between them as "internodes". The nodes occur at irregular distances, although in much greater density on trunk roots than on drop roots. This has important implications for the utilization of $H$. flexuosa that will be explained below. In $H$. flexuosa drop root specimens that I collected, internodes had an average length of $3.12 \mathrm{~m}$ and the longest internode was approximately $18 \mathrm{~m}$. Mature roots (linked series of nodes and internodes) were $3-7 \mathrm{~mm}$ in diameter at the base and usually larger (up to $1.1 \mathrm{~mm}$ ) towards the apical meristem. The basal narrowness of roots near the plant stem may be due to stretching from the weight of the entire root. The mean root diameter above individual nodes $(5.8 \mathrm{~mm})$ was slightly larger than below nodes $(5.4 \mathrm{~mm})$.

\section{SEXUAL REPRODUCTION AND PHENOLOGY}

Heteropsis produces inflorescences borne terminally on determinant side shoots from mature clusters (Grayum 1990, Fig 1.2). The spathe is caducous and yellow-white to green or reddish (yellow-white in $H$. flexuosa). The spadix is whitish-yellow, with bisexual flowers, and is shorter than the spathe. The mature infructescence is club-shaped, with yellow or orange berries, each containing one to five black seeds. The seeds, 
approximately $1.2 \mathrm{~cm}$ in length and $1 \mathrm{~cm}$ in width, are among the largest known in the Araceae (Madison 1979). I collected ten Heteropsis flexuosa infructescences in 1996 and measured the undried dimensions and the number of fruits per infructescence. The mean length (including curvature along the axis) was $11.1 \mathrm{~cm} \pm 2.3 \mathrm{s.d}$ (range: $8.3-16.1$ ) length. I measured three widths: apical, $3.0 \mathrm{~cm} \pm 0.5(2.1-4.0)$; mid-point, $3.1 \mathrm{~cm} \pm 0.6$ (1.8 - 3.8); and basal, $2.8 \mathrm{~cm} \pm 0.6(1.7-4.2)$. I counted $38 \pm 8.6$ s.d. $(30-58)$ fruits per infructescence

I observed both fruiting and flowering specimens of Heteropsis flexuosa in most months of the year and in rainy and dry seasons. In August, the beginning of the dry season in Guyana, I found only inflorescences. Flowering of $H$. flexuosa in French Guiana has been documented in the early rainy season (Dec-Mar) and mature fruits in March, May and November. The presence of caducous, yellow-white spathes on the forest floor was the best clue for locating fertile $H$. flexuosa in the canopy. Plants are probably pollinated by beetles or bees and dispersed by birds or rodents, although I observed no pollination or dispersal events. Romero (1993) mentions that the fresh spadices of Heteropsis spruceana smell of methyl benzoate, a known attractant for euglossine bees. Davis and Yost (1983) cite the consumption of Heteropsis inflorescences by oropendulas, toucans and monkeys. 


\section{C) FIELD IDENTIFICATION}

Gentry (1993) described Heteropsis as the genus "least obviously an Araceae when sterile". This aberrant morphology is helpful in identifying the genus in the field. There are no other aroids and few other epiphytic taxa with plagiotropic branches, distichous leaf arrangement, and tough aerial roots. In addition, every internode in Heteropsis flexuosa has a characteristic spur-like lateral bud that can be spotted with binoculars. Seedlings and juvenile $H$. flexuosa also have the lateral buds and have distinctive lanceolate, coriaceous leaves with very fine parallel veins.

The only similar genus is Marcgravia, but close-up there are obvious differences. Distinguishing characteristics of Marcgravia include lanceolate leaves with non-monocot reticulate veins, climbing stems square or rectangular in cross-section, and juvenile leaves overlapping and closely appressed to the host trunk.

H. flexuosa absorbing roots are easily distinguishable from those of other aroid and nonaroid taxa. The nodes described above are not diagnostic because they occur on several aerial-root-producing taxa in Guyana. The only aerial roots in Guyana similar to Heteropsis roots are those of Evodianthus funifer (Poit.) Lindm. (Cyclanthaceae), usually called "mamure" and occasionally "nibbi" in Guyana. This is another secondary hemiepiphyte used by indigenous groups for the same purposes as Heteropsis, although it is not used in the furniture industry. Roots of $E$. funifer have a larger diameter (5 -13 mm) than $H$. flexuosa roots, are less flexible, and have a orange-reddish hue. 
To assure that I did not collect data on more than one Heteropsis species, I reviewed literature, plant keys and herbarium specimens. To confirm my opinion, Dr. Tom Croat at the Missouri Botanical Garden has determined some of my collected material as $H$. flexuosa. At least five Heteropsis species have been collected in Guyana: H. flexuosa, $H$. melinonii (Engl.) Fonker, Verhoef \& Fonker, H. oblongata (Kunth) Croat, H. spruceana Schott, and H. temispadix Bunting (Funk et. al. 1996; H. longispathacea may have been collected also). In Bunting (1996), a key to the species of Venezuelan Guayana includes H. flexuosa, H. melinonii, H. spruceana, H. steyermarkii Bunting and H. temuispadix. An unpublished key to species in French Guiana (Grenand) includes $H$. flexuosa, $H$. spruceana, and $H$. steyermarkii. Character states used in the available keys include: petiole length and degree of sheathing, leaf blade color and texture, midrib raised or sunken, stem robustness and flattening, and the size and shape of the spathe and spadix.

The distinguishing characteristics of $H$. flexuosa in the Bunting (1996) key include: petiole not sheathed, adaxially canaliculate; leaf blade green or yellowish and coriaceous; stem stout (to $1 \mathrm{~cm}$ thick); spadix to $6 \mathrm{~cm}$ long at anthesis and infructescence $12-15 \mathrm{~cm}$ long. H. flexuosa is not difficult to distinguish from other Heteropsis species in the keys due to the robustness of stems and infructescences. H. spruceana var. robusta approaches the leaf blade dimensions of $H$. flexuosa, but the spadix and stems have smaller dimensions. H. oblongifolia was recognized by Oliver (1890) as the species most closely alligned with $H$. flexuosa, but so far it is only known in far western South America and 
Central America. The spadix of $H$. oblongifolia is much smaller and the leaves less oblanceolate than $H$. flexuosa. A. C. Smith (1939) recognized H. macrophylla as the closest ally of $H$. flexuosa but with leaves "less gradually narrowed at the extremities and lacking an acuminate tip, and... having a very regular collecting nerve extremely close to the leaf margin."

\section{D) GROWTH STAGE DEFINITIONS}

For the purposes of my study I defined three size classes for Heteropsis flexuosa (Fig. 1.1). The seedling class is a seedling or young climber lacking plagiotropic branches and absorbing roots. The juvenile class is an individual with a small diameter climbing stem $(<5 \mathrm{~mm})$, producing at least one plagiotropic branch. Small absorbing roots may be present and the original climbing stem decomposed. This stage can occur as little as $0.5 \mathrm{~m}$ high on the host tree. A mature $H$. flexuosa stem has one or more mature clusters ( $>5$ $\mathrm{mm}$ stem diameter), with full-size plagiotropic branches and well-developed aerial roots Young size classes at tree bases can be identified as individuals or genets, but the mature stems cannot due to their vining habit.

Stages of root maturation are morphologically distinct. Very young nibbi roots are whiteish with brown marks, soft, and make a distinctive "crinkling" sound when bent, due to the tearing of immature vascular tissue. Roots of intermediate maturity are brown-ish with white marks and provide a slight "crinkle" sound. Mature roots are woody and tough as described above. 


\subsection{Physical GeOgRAPHY}

\section{A) LOCATION (GUYANA AND STUDY SITES)}

Guyana, a small country of approximately 19.6 million hectares (about the size of Idaho) lies on the remote north-eastern shoulder of South America (Figure 1.4). The country is bounded by the Atlantic Ocean to the north, Venezuela to the north-west, Brazil to the south and south-west, and Suriname to the east. Guyana is the westernmost of the three "Guianas" (Guyana, Suriname, French Guiana).

I conducted fieldwork between October 1995 and August 1996 within two general regions of Guyana. In the Northwest District, I studied Heteropsis flexuosa on the forestlands of the mixed Arawak and Carib indigenous community of Manawarin $\left(7^{\circ} 30^{\prime} \mathrm{N} \& 59^{\circ} 0^{\prime} \mathrm{W}\right.$ ) The Manawarin River watershed is an area of approximately 130,000 ha (Fig. 2). In addition, I established study sites $320 \mathrm{~km}$ (200 miles) to the south, at the Iwokrama International Rainforest Reserve in central Guyana ( $4^{\circ} 30^{\prime} \mathrm{N}, 58^{\circ} 50^{\prime} \mathrm{W}$ ) (Fig. 3). The 360,000 ha reserve was established after the former president of Guyana, the Honourable

Desmond Hoyte, offered the land for international research and conservation at the 1989 Commonwealth Heads of Government Meeting in Kuala Lumpur, Malaysia. The reserve (hereafter referred to as "Iwokrama") is named after the prominent, centrally-located Iwokrama Mountains. 


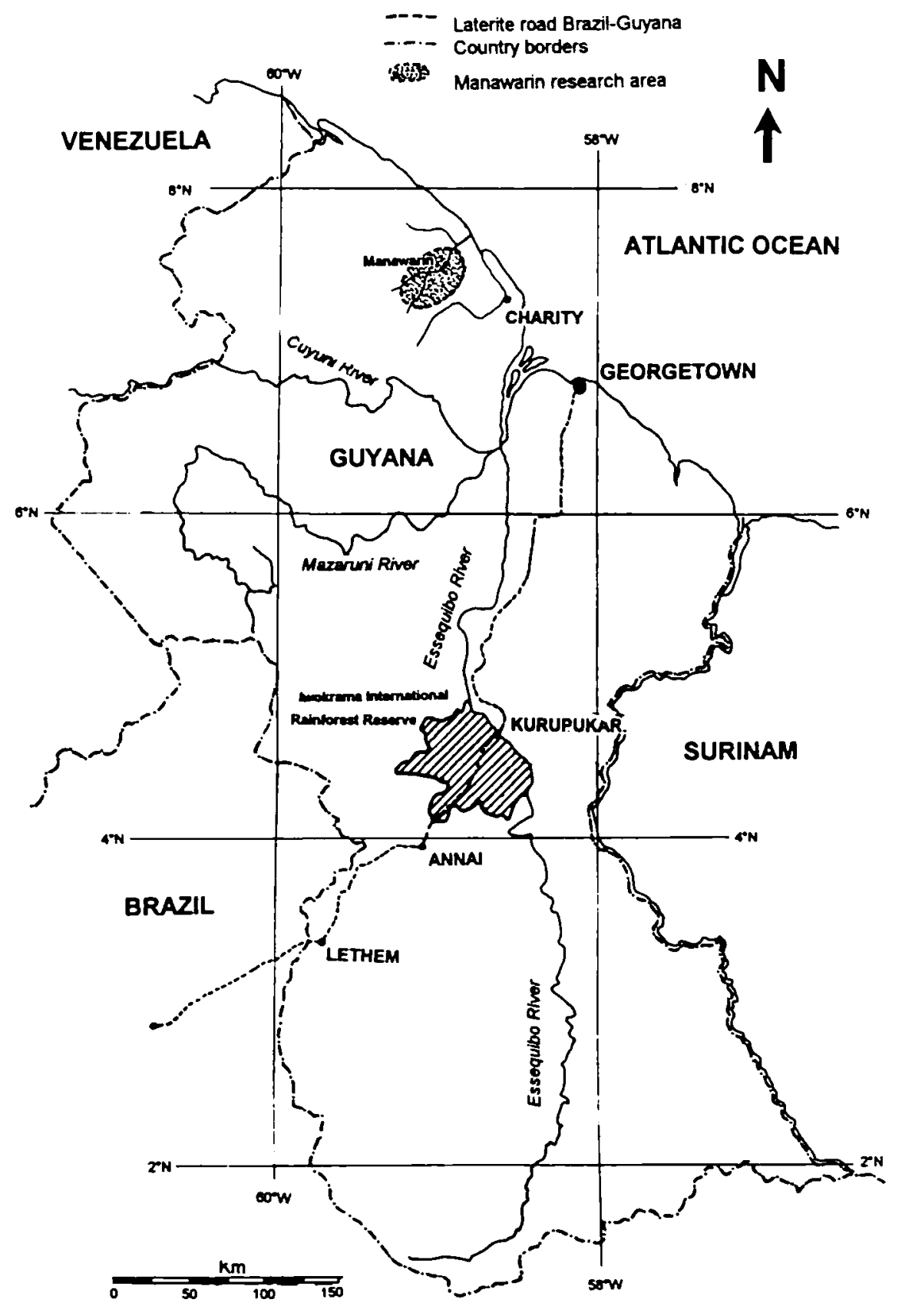

Figure 1.4 Map of Guyana with location of Manawarin and Iwokrama study areas 


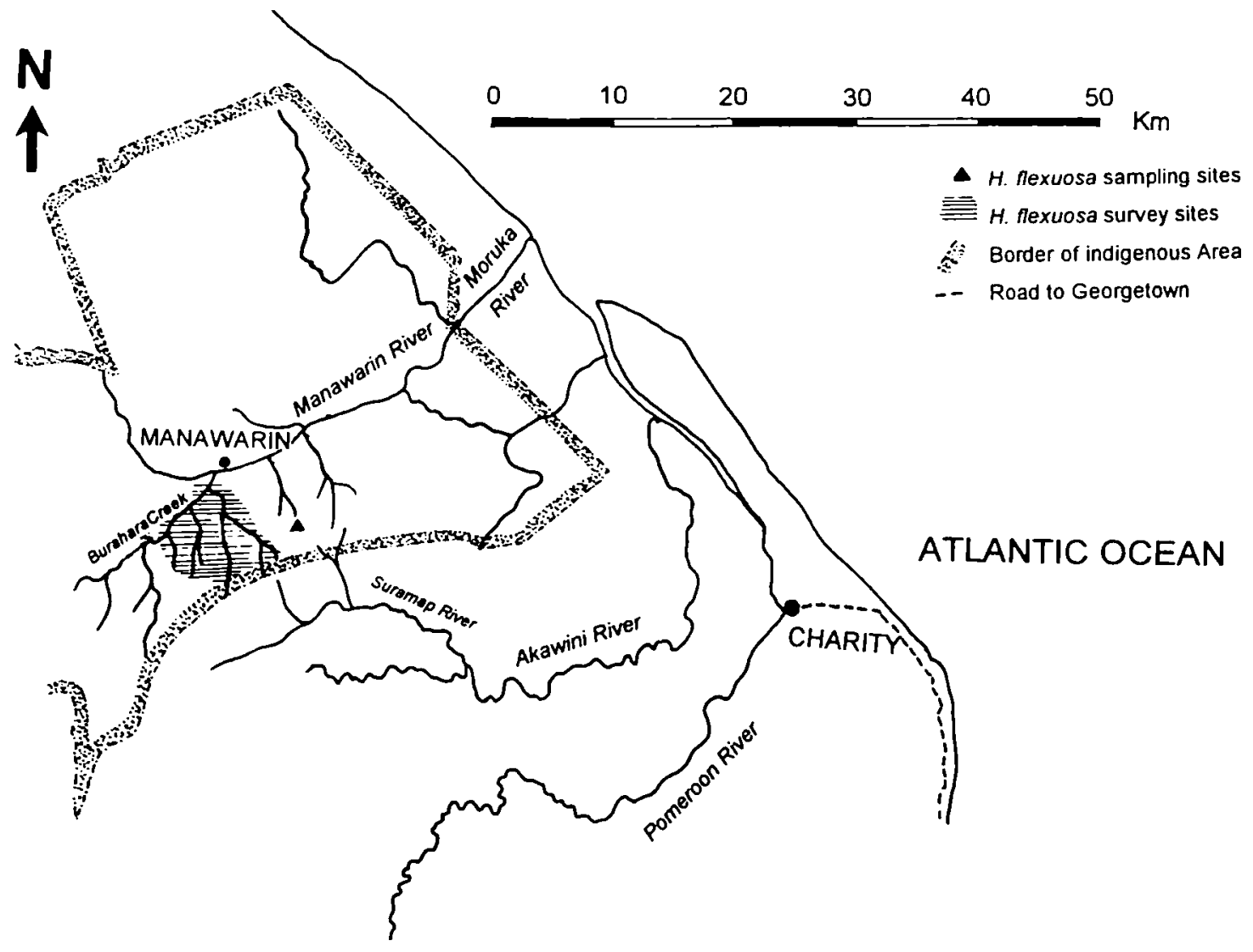

Figure 1.5 Map of Manawarin and Pomeroon River Area, Guyana 
Fis Iwokrama international Rainforest Reserve

-.. Laterite road Brazil-Georgetown

H. Mexuosa sampling sites

- H. fexuosa survey sites

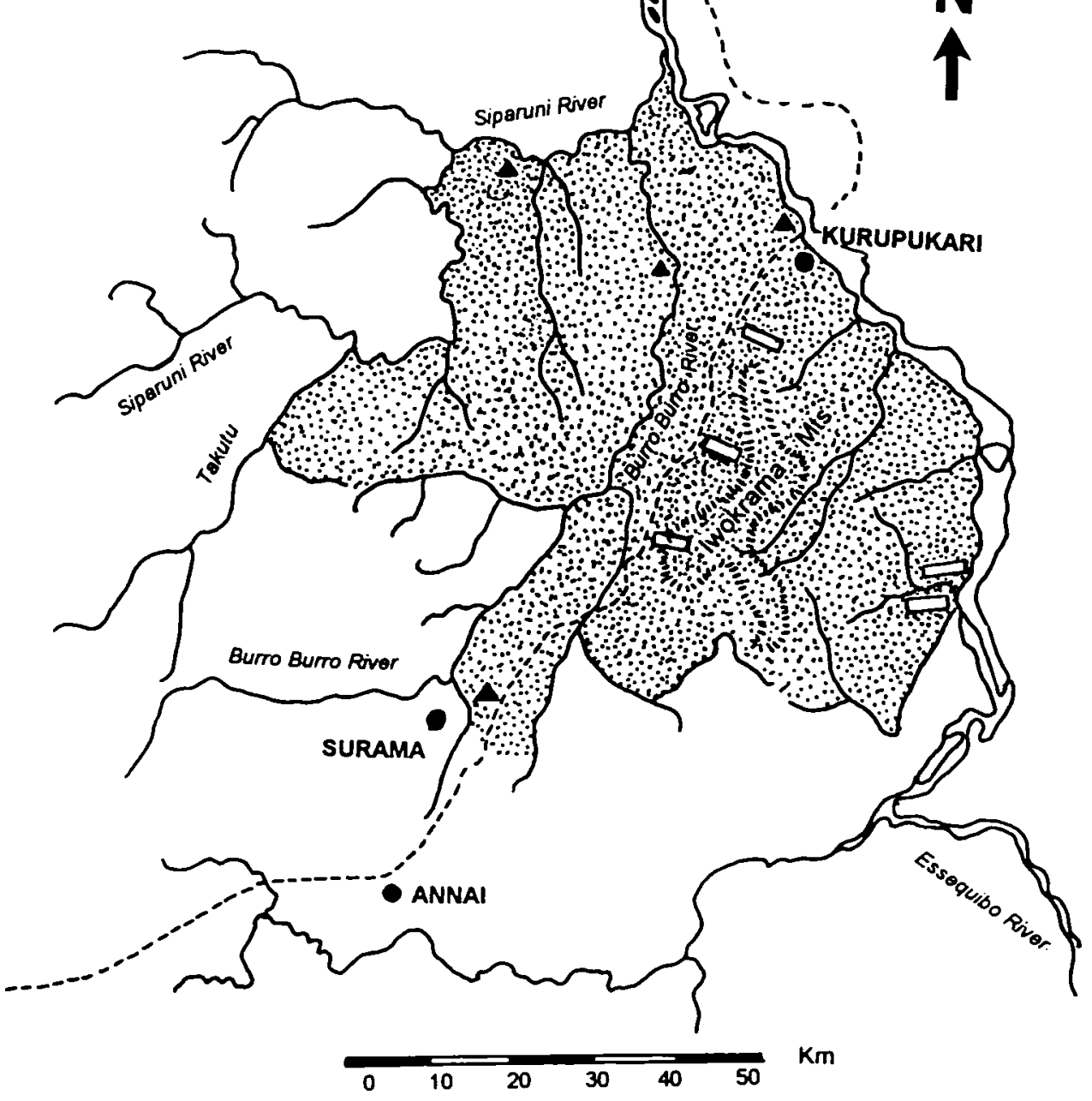

Figure 1.6 Map of Iwokrama International Rainforest Reserve 


\section{B) GEOLOGY AND SOILS}

There are four major geomorphological areas recognized in Guyana, including the Pre-Cambrian Plateau or Guiana Shield, the Coastal Plain, the White Sands Plateau or "sandy rolling lands", and the Pakaraima Mountains (Daniel and Hons 1984; ter Steege 1996; UNCED 1992; Fig. 1.7). The Guiana Shield is a pre-cambrian igneous and metamorphic basement layer underlying all of northeastern South America, one of the "earliest shields of the earth's crust" (Huber, 1995). In large areas of north, central, and southern Guyana (also portions of Brazil, Venezuela, Colombia, and the other Guianas), the Shield directly underlies plant communities. In Guyana, it is covered mostly by forest on undulating topography $(15-300 \mathrm{~m})$ and by the extensive Rupununi savannahs. Soils include brown sands and sandy loams (ultisols), alluvial deposits (entisols), and occasional lateritic clay (ultisols and oxisols) [USDA classification 1975]

The Coastal Plain consists primarily of marine alluvium and ranges in width from $25 \mathrm{~km}$ to $75 \mathrm{~km}$, representing only $7.5 \%$ of Guyana's land. East of the Pomeroon River, the White Sands Plateau (Berbice formation) overlies the Guiana Shield and extends southwards from the coast as far as $200 \mathrm{~km}$ (125 miles) on forested, undulating terrain. The dominant soil types are excessively-drained, nutrient-poor white sands (entisols) and slightly betterdrained, less nutrient-poor brown sands (ultisols). The Pakaraima Mountains are the easternmost extension of the Guayana highlands, an area of spectacular table mountains 
with a highly-endemic flora. The highlands result from a 400 to $2000 \mathrm{~m}$ thick sedimentary sandstone and quartzite layer (the Roraima Formation) deposited over the Guiana Shield (Huber 1988). The highest mountains in Guyana are eroded remnants of the Roraima Formation, including Mt. Roraima to $2772 \mathrm{~m}$ and Mt Ayanganna to $2134 \mathrm{~m}$. Soils are predominantly entisols, oxisols, ultisols, and histosols. Throughout Guyana, lateritecovered doleritic dykes and granite batholiths intrude through the basement layer and the Roraima formation, resulting in steeper reliefs (to $1000 \mathrm{~m}$ ) and pockets of higher soil fertility on laterite soils (ultisols and oxisols).

\section{Iwokrama and Manwarin sites}

The Iwokrama reserve is underlain by the Guiana Shield, with a slight extension of the White Sands Plateau (Berbice formation) on the northern border. It is a topographically diverse region with floodplains, undulating terrain, small hills, and mountains to $800 \mathrm{~m}$ elevation. Soils at the Iwokrama study sites included well-drained and poorly-drained brown sands (ultisols), hill soils in the Iwokrama mountains (ultisols), and alluvial soils (entisols).

The Manawarin watershed is an ecotone between the tidal marshes and alluvium of the Coastal Plain and the undulating terrain of the Guiana Shield (rising to $20 \mathrm{~m}$ ). The forest soils observed are similar to those at lowland Iwokrama sites, with brown sands (ultisols), silts, alluvial deposits (entisols), and occasional lateritic clay (oxisols). 


\section{C) CLIMATE}

Due to the combined effects of the shifting Intertropical Convergence Zone (ITCZ) and the tradewinds, there is a bi-modal weather pattern in most of Guyana, with two wet and two dry seasons (Huber 1995, ter Steege 1996, Figure 1.8). The long rainy season lasts from May to August and the shorter one from December to February. The driest time is September to October, but the dry seasons still average $100 \mathrm{~mm}$ of rain per month. Annual rainfall averages $2500 \mathrm{~mm}$ with a maximum of $4400 \mathrm{~mm}$ on the rainy eastern side of the Pakaraimas and a minimum of $1700 \mathrm{~mm}$ in eastern Guyana. The average annual temperature is $25^{\circ} \mathrm{C}$ at sea level with an annual range of less than $5^{\circ} \mathrm{C}$. As typical of the tropics, the diurnal range of temperatures exceeds the annual range.

\section{Iwokrama and Manwarin sites}

Iwokrama is located at a transition zone between maritime and continental climates. The dense rain forest that covers most of the reserve is bordered to the south by the Rupununi savannahs. The only long-term records for rainfall come from Karupukari village, one of the rainiest locations within the reserve (along the Essequibo River). Mean annual rainfall of $2500 \mathrm{~mm}$ was documented at Karupukari, with a range of 2000-3000 mm (Hawkes and Wall, 1993). The two wet seasons received an average of 1350 and $400 \mathrm{~mm}$ rain, with $750 \mathrm{~mm}$ falling in the remaining six months. The climate at Manawarin is fully maritime, with an average $2600 \mathrm{~mm}$ of rainfall annually. 


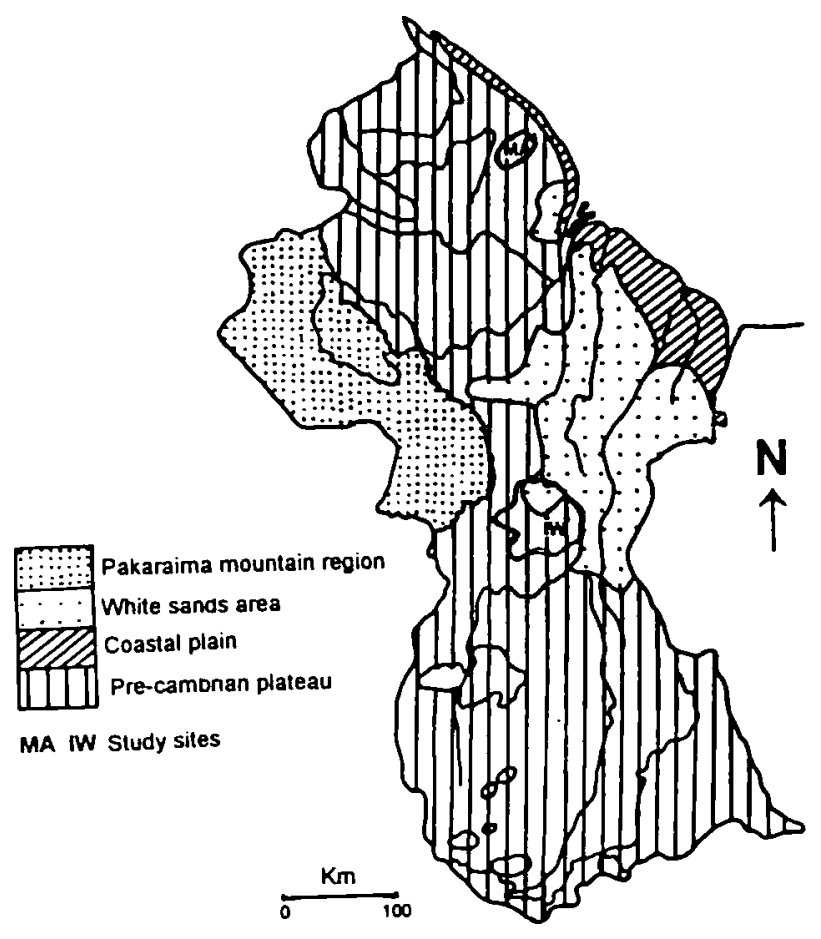

Figure 1.7 Map of major landscape types in Guyana

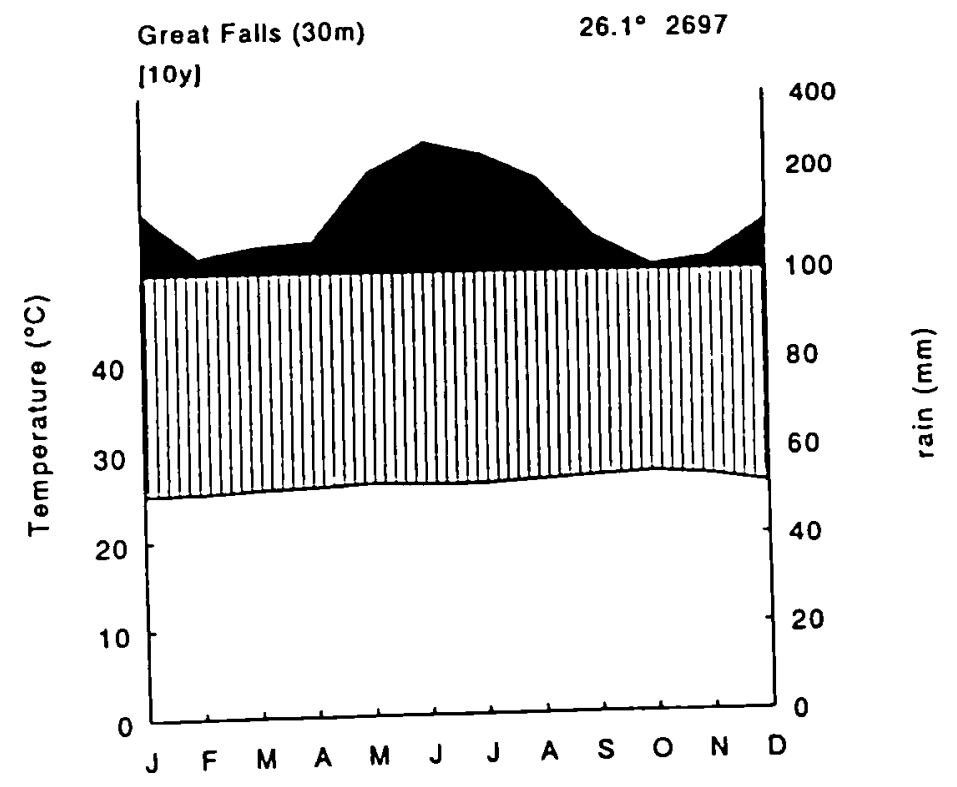

Figure 1.8 Climate diagram for Great Falls, $80 \mathrm{~km}$ north of the lwokrama research area. After ter Steege at. al. 1996. 


\section{D) VEGETATION}

The Guianas region encompasses one of the world's few remaining relatively undisturbed and vast tropical bioregions: the forests, savannahs and swamps north of the Amazon River basin and Rio Negro and east of the Orinoco River. Approximately 14 million hectares or $83-86 \%$ of Guyana is covered by forest (Haman and Wood 1928). According to the Holdridge Life Zone system, most of Guyana is classified as Tropical Wet Forest (Holdridge et. al. 1978). The diverse ecosystems of Guyana contain more than 6500 vascular plant species, including many endemic species (Funk et. al. 1993 and WCMC 1992). Fanshawe (1952) lists six primary vegetation types for Guyana including: 1. rain forest; 2 . seasonal forest; 3 . dry evergreen forest; 4 . montane forest; 5 . marsh forest (includes seasonally inundated savannahs); and 6. swamp forest (including mangroves and constantly inundated savannahs). A recent vegetation map of Guyana recognizes five primary forest types (excluding shrublands, savannahs. meadows, and saxicolous vegetation): 1. flooded coastal and lowland forests; 2 . non-flooded lowland forests; 3 . non-flooded lowland forests on white sand; 4. montane forests; and 5. riparian forests (Huber et. al. 1995).

Unlike much of the tropics, the forests of Guyana often are dominated by one or two tree species, facilitating recognition of forest types associated with particular soil types or conditions (Fanshawe 1952; Johnston and Gillman 1995; Table 2.1.). Davis and Richards (1933) recognized five intergrading forest types in their classic tropical ecology paper on central Guyana's lowland rainforests: Mora (Mora excelsa Benth.), Morabukea (Mora 
gonggrijpii Sandw.), Mixed (no dominance), Greenheart (Chlorocardium rodiei

(Schomb.) Rohwer et. al.) and Wallaba (Eperua falcata Aublet). Mixed rain forest (sensu Davis and Richards) exists in moderate drainage conditions, with a similar set of species in changing ratios of dominance. The variation within mixed forest is large and there have been several attempts at a finer scale definition. Ter Steege et. al. (1996) use soil drainage as the primary factor in classifying the lowland forest habitats at Mabura Hill, central Guyana.

\section{Manawarin and Iwokrama}

The Manawarin watershed consists of herbaceous swamp and palm marsh woodlands in its lower reaches tall evergreen non-flooded forest on surrounding hills to $30 \mathrm{~m}$ (Huber et. al. 1995). The forests of the Manawarin area remain largely intact despite their proximity to coastal populations because they are on protected Amerindian land. Forest types (sensu Davis and Richards) include Mixed, Mora, and Swamp forest. I did not observe Wallaba (the White Sand Plateau is not present) or Greenheart forest.

The Iwokrama International Rainforest Reserve is a remote, pristine and ecologicallydiverse region of tropical forest with riverine, swamp, upland and mountainous habitats up to $300 \mathrm{~m}$. Huber et. al. (1995) classify the primary vegetation type at Iwokrama (like Manawarin) as tall evergreen non-flooded forest. All the forest types recognized by Davis and Richards are found within the boundaries of the reserve. 


\subsection{HUMAN GEOGRAPHY}

\section{A) THE PEOPLE}

Guyana, formerly known as British Guiana, achieved it's independence from Great Britain in 1966. Today, it's population is estimated at 760,000 with $90 \%$ concentrated in urban and agricultural areas along the fertile coastal alluvium. The people on the coast are largely Indo-Guyanese (East-Indian) and Afro-Guyanese, with a Caribbean cultural life The Afro-Guyanese are the descendents of slaves brought in the 1700's and the IndoGuyanese are descended from indentured servants who came in the 1800's after slavery was abolished.

The interior is lightly populated with indigenous settlements, military outposts, and mining shanty towns. There are nine major indigenous groups in Guyana (est. 40,000 individuals) occupying 65 reserved areas, districts and villages, with land rights to about 1.4 million hectares (Forte 1996). The indigenous people of Guyana are referred to as Amerindians to distinguish them from the East-Indians. I worked with Locono Arawak (Arawak speaking) and Carib/Karinya (Carib speaking) people at Manawarin village in the NorthWest District and with Macushi (Carib Speaking) and Wapishiana (Arawak speaking) people near the Iwokrama International Rainforest Reserve. 


\section{B) THE ECONOMY AND NATURAL RESOURCES}

After independence, Guyana spent 20 years under the rule of "socialist" dictatorship, with its people and natural resources isolated from the western world (a low population and physically inaccessible interior also protected resources). With an estimated US $\$ 350$ per capita gross national product and US $\$ 2000$ per capita debt, Guyana is one of the poorest and most indebted countries in the world (Colchester 1991). Beginning in the mid-eighties, the government adopted an economic liberalization policy (in part due to pressure from the International Monetary Fund and the World Bank) and opened parts of the interior to foreign mutinational companies. Guyana's minimally exploited natural resources have been "re-discovered" by global capitalism. Between 1990 and 1997, numerous timber and mining concessions have been awarded and there are more under consideration. Particularly noteworthy is a 1.6 million hectare $(5 \%$ of Guyana) timber concession in the North-West District, awarded to a Malaysian/South Korean consortium, Sung Kyong (calling itself the Barama company) in 1991.

Guyana received negative international attention briefly in 1996, due to a large spill of cyanide-tainted pond water into the Essequibo River (the largest river in the country) from a Canadian gold mining operation. Recently, Kwitaro Investors (another S.E. Asian firm co-opting an indigenous name) has spent millions for "exploratory leases", hoping to gain logging concessions in southern Guyana. Although assurances are routinely made that such logging operations will be "sustainable", the government does not have the staff or the funding necessary to monitor resource extraction projects. In attempting to appease 
the IMF/World Bank and the aspirations of its citizens for rapid economic gain, Guyana's government could squander the potential long-term economic and ecological wealth of its interior lands. In addition, with loss of biodiversity and ecosystem function will come further disintegration of Amerindian culture in Guyana. My research is a case study of one forest product that could provide an alternative to the "business as usual" focus on largescale logging and mining by outside interests.

C) USE OF NIBBI (HETEROPSIS FLEXUOSA)

\section{TRADITIONAL USES}

The tough, flexible aerial roots of Heteropsis species are a preferred fiber material of many indigenous groups in the neotropics. Whole or split, de-corticated roots are used for basketry, house construction, backpacks, fish traps, crafts and as a multi-purpose rope substitute (Bennett 1992b, Davis and Yost 1983, Gillin 1936 (possibly a cyclanth), Glenboski 1983, La Rotta et. al. 1987, Milliken et. al. 1992, Oliveira et. al. 1991, Paz y Mino C. et. al. 1995, Romero 1993, Salick 1992). The Wai-Wai people of southern Guyana traditionally wore head ornaments of nibbi fiber and red toucan feathers during a sun invocation ceremony. In Guyana, every indigenous community I visited used nibbi, even if it could only be found far from the village. If nibbi is not available, then the closest substitute is used, usually the aerial roots of a cyclanth or another aroid species. 


\section{HARVEST AND PRELIMINARY PROCESSING OF NIBBI}

I obtained data on traditional harvest methods through direct observation in the field and through informal interviews with local harvesters and their families. My primary indigenous collaborators from Manawarin Village included James Miguel, Erwin Miguel, Owen Williams, Kendrick Williams, and Gillbert Adams. I also obtained valuable information from Eddie Persaud and his family (East Indian) and Samuel Sobers (Arawak) on the Pomeroon River. At Iwokrama, I worked with Macushi people from Surama Village and mixed indigenous people from Karupukari Village. My principal indigenous collaborators there were Daniel Allicock, Fred Allicock, Dennis Edwards, and "Rodrigues".

Nibbi collectors throughout Guyana harvest nibbi roots by simply ripping them down. They cut the root where it enters the ground, place one hand as high up on the hanging root as possible, grasp the loose bottom end of the root with the other hand and wrap it underneath the body (Fig 1.9). Maintaining this tight hold, the collector then pulls, using his body weight as an additional force, until the root breaks. The point of breakage is almost always at a node or at the stem, at an average distance of $10 \mathrm{~m}$. I observed hundreds of root pullings and only once was a mature stem torn down from it's host position.

The methods for subsistence harvesting are the same as for commercial harvesting, but done more casually, and often as a secondary activity to farming or hunting. I noticed no 


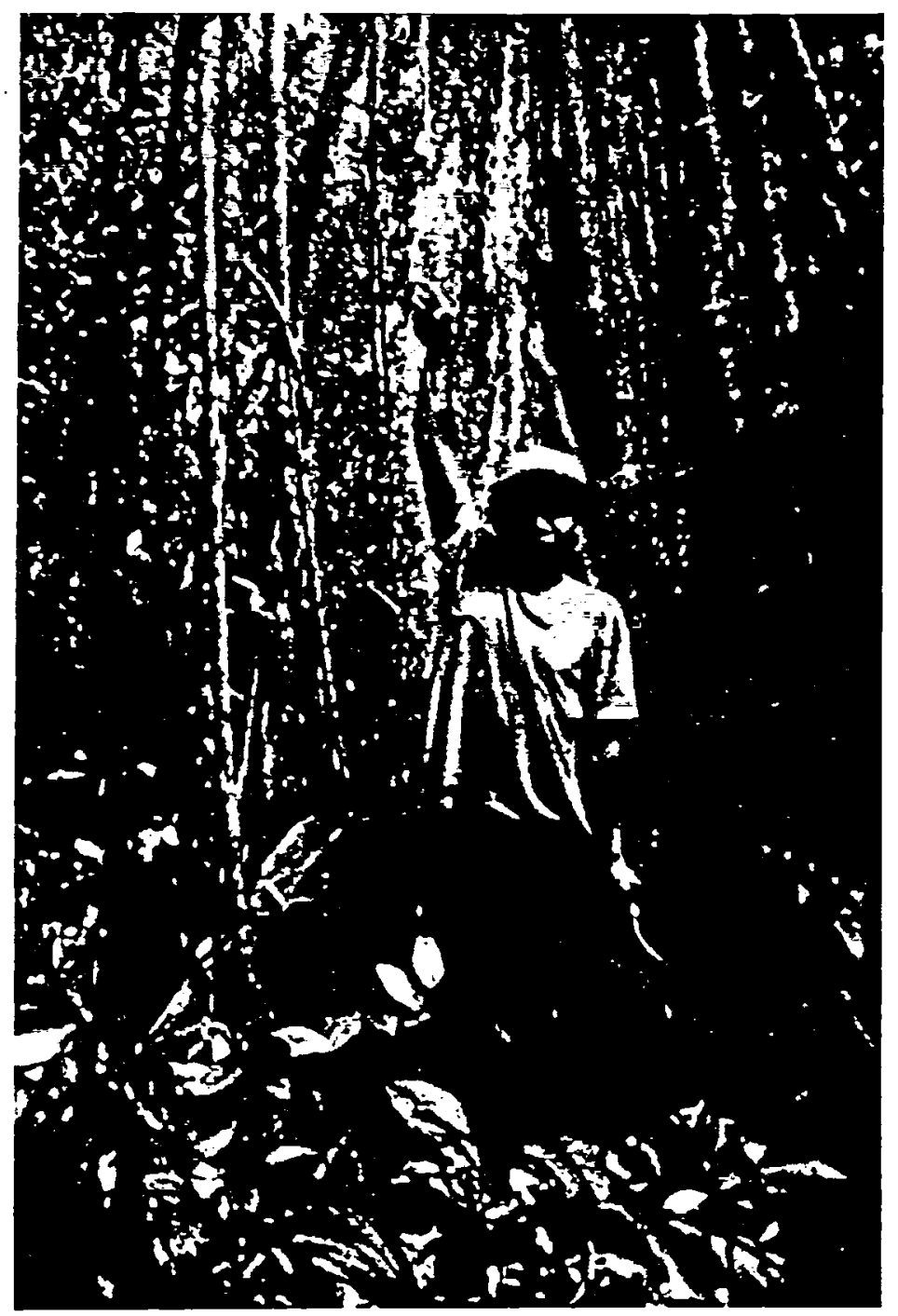

Figure 1.9 James Miguel, nibbi harvester from Manawarin village, showing correct method for pulling down Heteropsis flexuosa aerial roots. Aerial roots of another useful fiber plant, kufa (Clusia spp.), are visible on the left. 


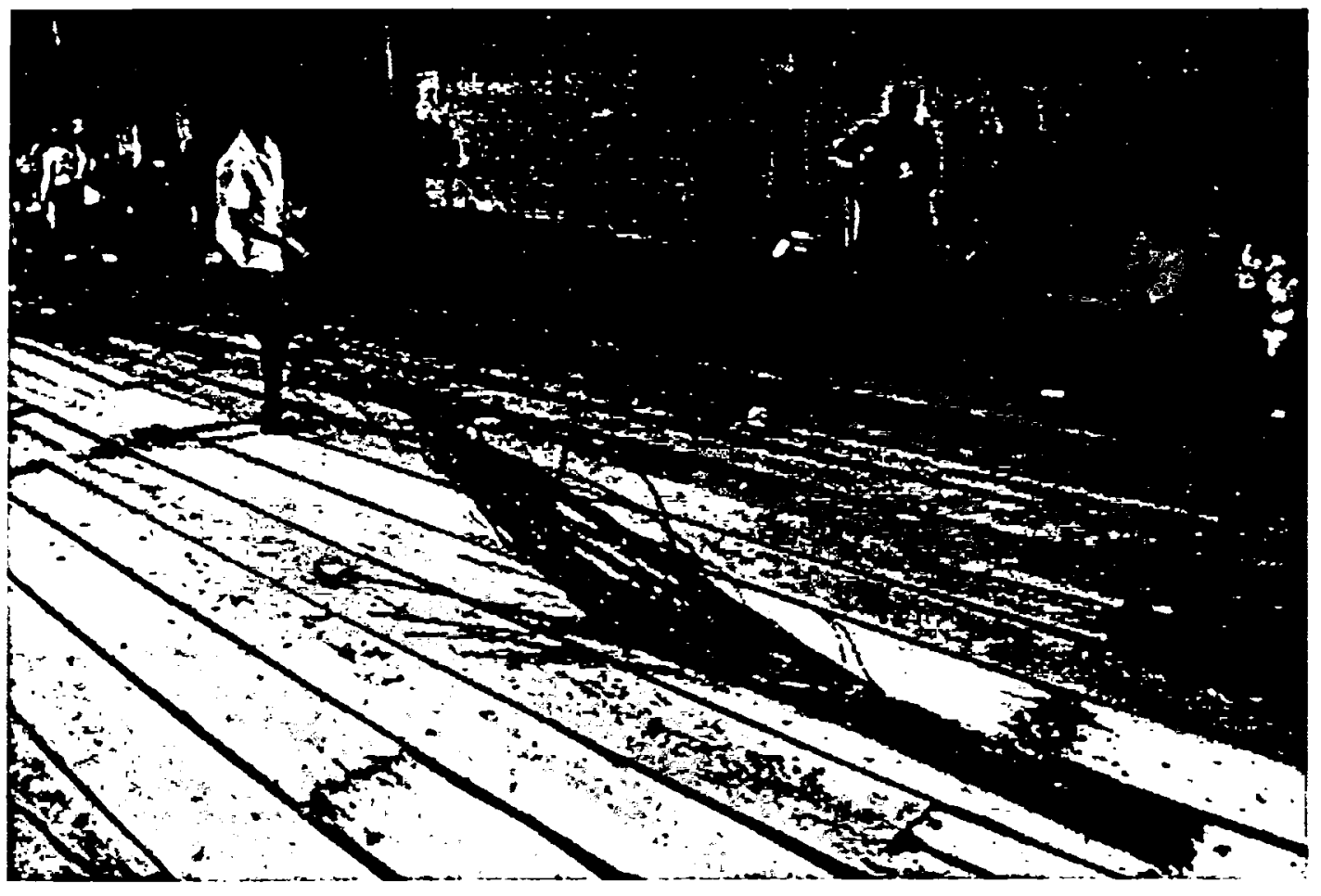

Figure 1.10 Unrolled nibbi bundle of 100 pieces (Heteropsis flexuosa) showing variable lengths. 


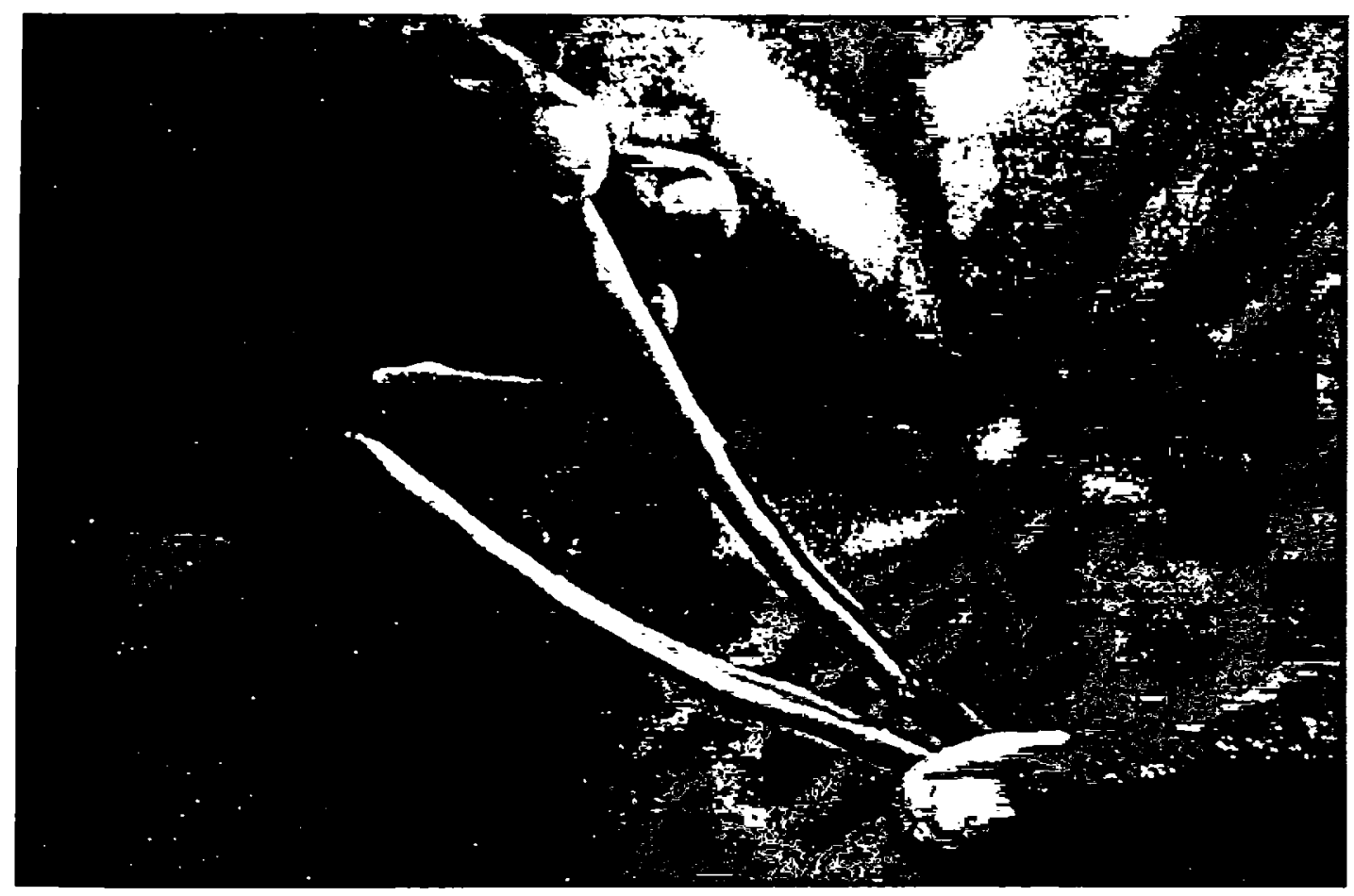

Figure 1.11 Processing of nibbi roots: peeling away the cortex of Heteropsis flexuosa. 


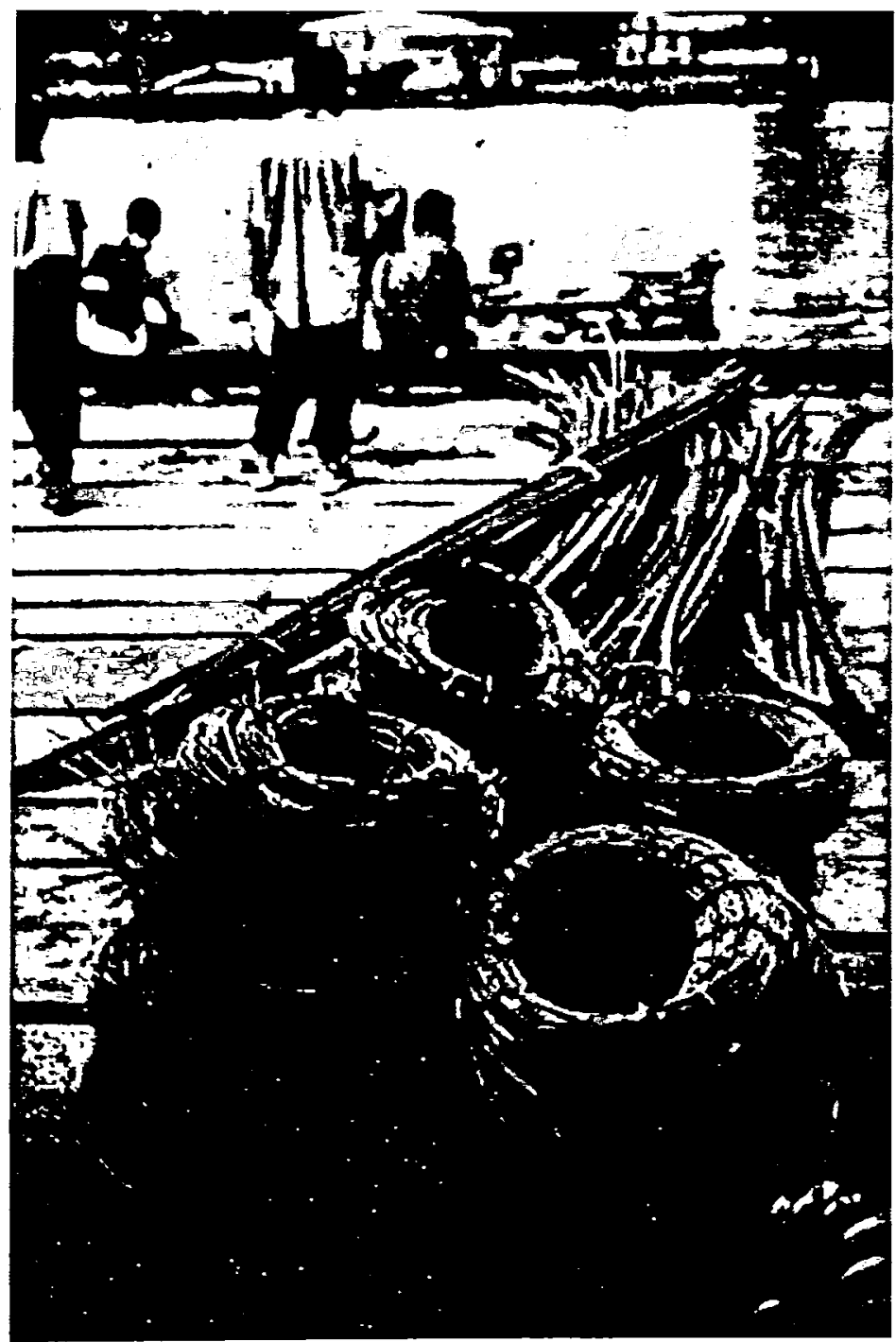

Figure 1.12 Nibbi roots (Heteropsis flexuosa) in circular bundles at Charity market, Pomeroon River. Kufa (Clusia spp.) cut root lengths are visible in background. 


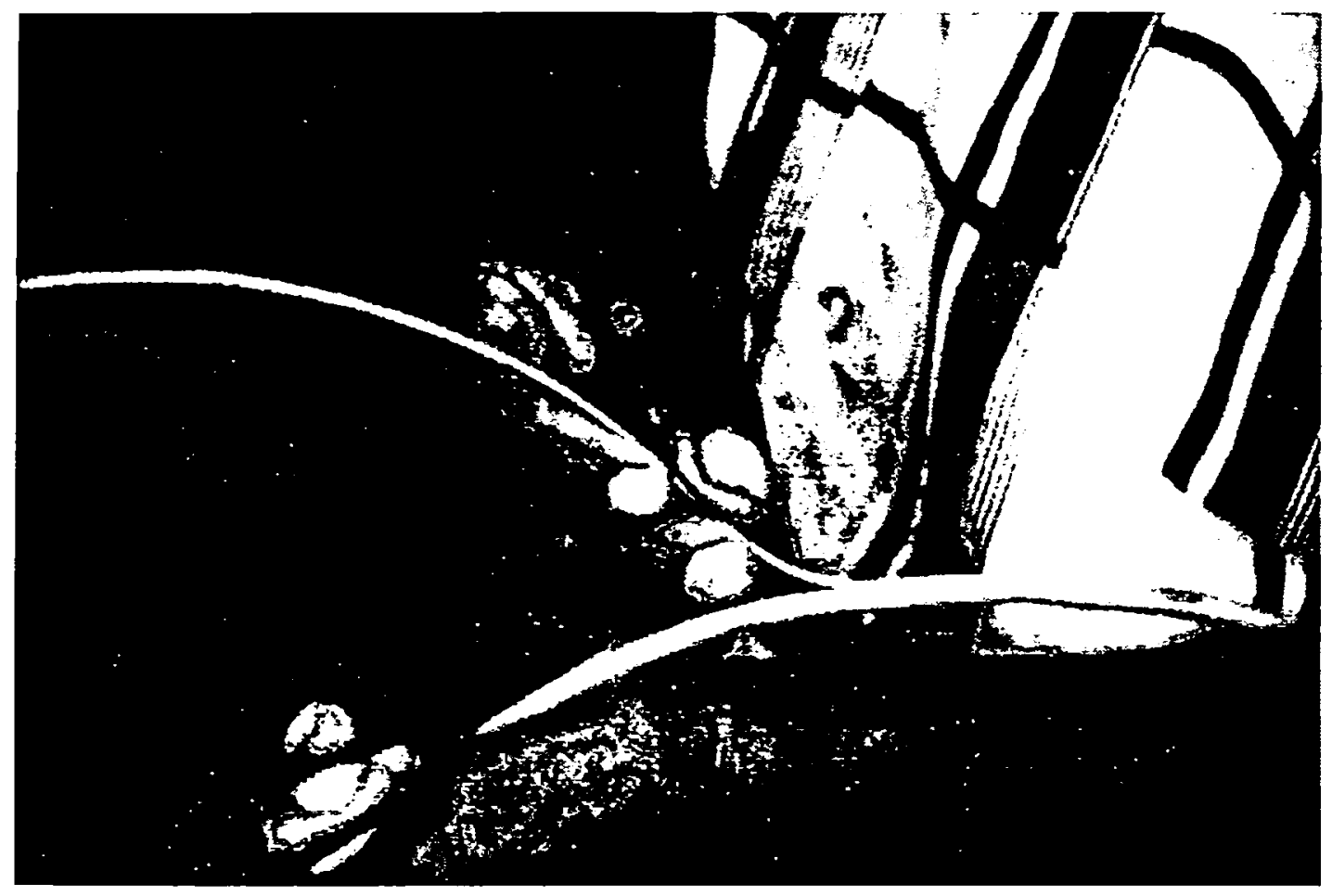

Figure 1.13 Processing of nibbi roots: splitting the stele of Heteropsis flexuosa longitudinally. 


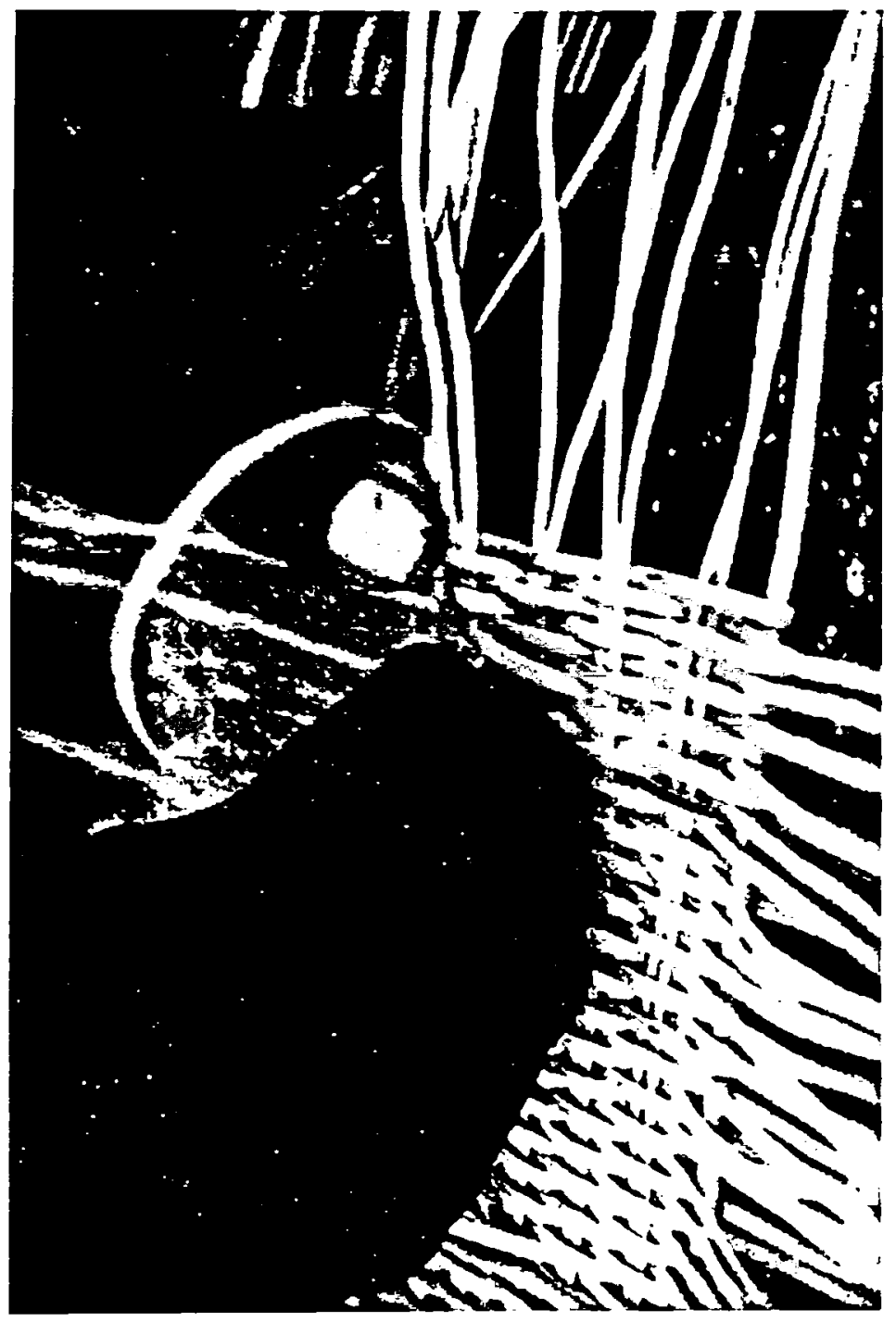

Figure 1.14 Indigenous use of nibbi: A Wapisiana man in southern Guyana plaits a basket from Heteropsis flexuosa root strips. 


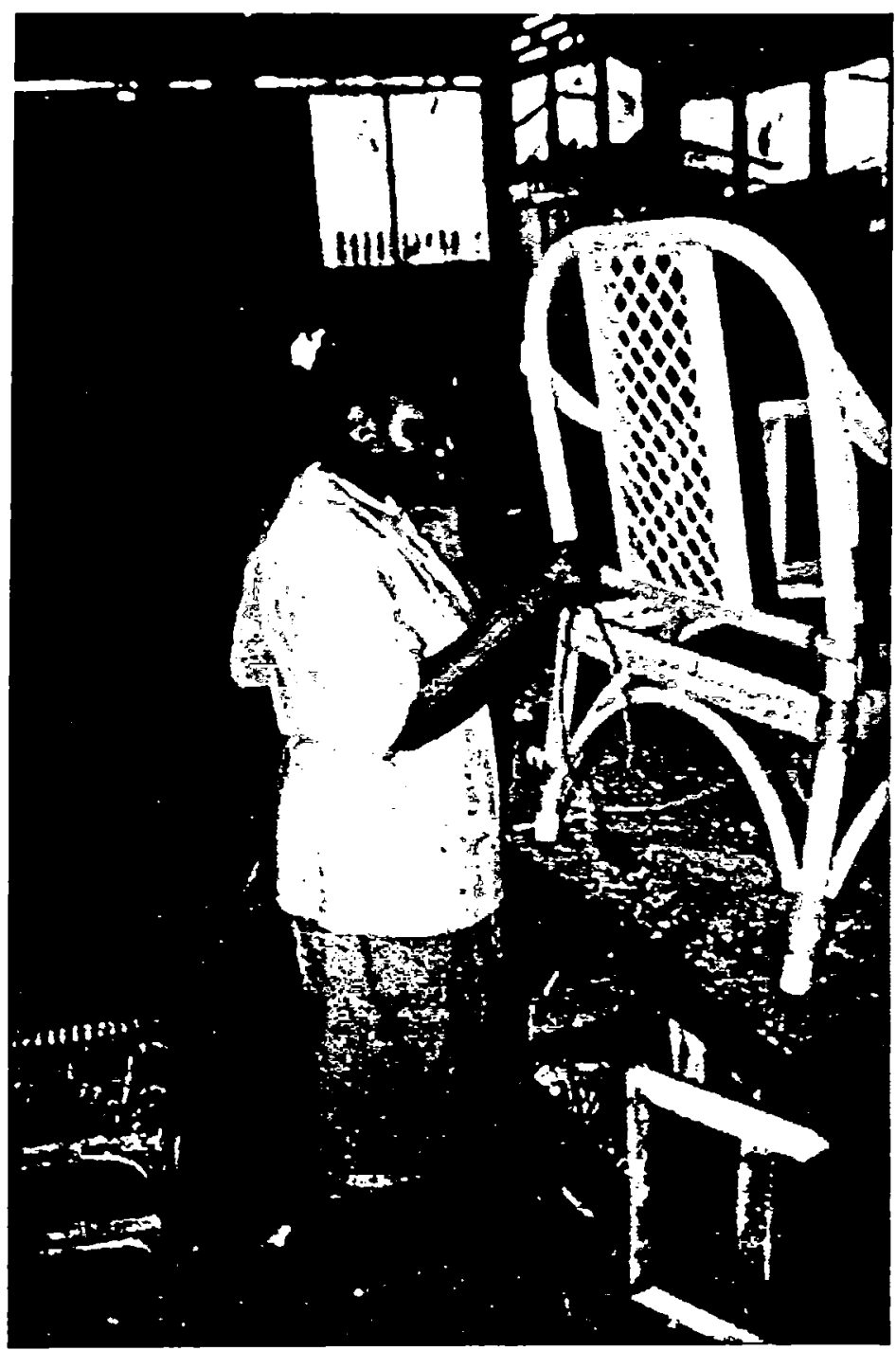

Figure 1.15 Nibbi chair assembly at Liana Cane Interiors furniture factory. Nibbi (Heteropsis flexuosa) is used for seats, joints and chair backs. Kufa (Clusia spp.) provides the frame. 
difference in methods between Iwokrama and Manawarin harvesters. Because commercial harvesting does not yet occur in the Iwokrama area, the description here is taken from my experience at Manawarin.

Nibbi collectors in the Manawarin area are generally older boys to middle-aged men, numbering approximately 30 individuals. Working in pairs or small groups, harvesters set up a basecamp in the forest or occupy a farm site and search from there for nibbi populations. Collectors walk for many miles on a given day, often passing up areas with low densities of nibbi. When a collector finds a good amount of root product, he harvests and processes it on the spot, leaving it near a trail or placing it in a stream for longer term storage. Collectors seek out roots that are straight, long, and with the fewest "nodes" (p. 17, Fig. 1.3). The collectors I worked with harvested only "drop" roots, those that fall straight down from branches or leaning trees. They ignored the "trunk" roots that wrap around the host trunk because these are twisted, have many nodes, and are more difficult to harvest. I was told that a few unscrupulous people harvest all the roots, despite the low yield and quality.

Once a root is pulled down, the nodes and low-quality sections are cut out and bundles of 100 (of varied lengths) are made out of product-quality internodes (Fig 1.10). Depending on the request of buyers, the root cortex is stripped from the roots or is left intact. The cortex is easily removed by flexing the root and peeling it away (Fig. 1.11). The cortex is left intact sometimes because it protects the stele from drying and mildew. The stele is the 
only part of the root used to make furniture and handicrafts. Grouped roots are hauled out of the forest, back to the basecamp, and brought down river by canoe to Manawarin village. Root internodes can be stored in water for up to three weeks without rotting. They can also be stored dry, but before being used they must be soaked for 24-72 hours to make them flexible. Root bundles are often rolled from one end into a tight circular form for transport to markets (Fig 1.12).

For plaiting work, the stele is used either whole or split longitudinally into strips (Figs.

$1.13,1.14)$. The strips are scraped with a knife to make them smooth. For binding, cordage, fish traps, belts, and other household or hunting uses the stele is also used whole or split.

\section{THE NIBBI CRAFT AND FURNITURE COTTAGE INDUSTRY}

Sufficient supplies of nibbi and kufa (Clusia spp.) are required together for furniture production. Nibbi root fiber (split or whole) is used to bind corners, make seats or backrests, and create aesthetic patterns around a framework of kufa (Fig 1.15). Kufa segments must first be soaked or steamed to make them flexible. They are then sanded, bent, nailed, and held in frames to form desired functional and artistic shapes. Fiber from the ite palm (Mauritia flexuosa) is also used in furniture for additional support or design on the kufa framework. Some designers use cast iron or wood as a component with kufa and nibbi. Inexpensive furniture is sold without any finishing, paint, or resin. 
The commercial harvest of nibbi and kufa for fumiture has historically occured only in the Pomeroon River region, including the upper Pomeroon, Akawini, and Waini Rivers (Fig 1.5). Harvesting in the Manawarin watershed began approximately six years ago. One local story is that the nibbi furniture trade began in the 1930's when an escaped convict from Devil's Island in French Guiana (Francis Frey) came to the Pomeroon River and began producing furniture on a small scale. He taught others his trade and the practice spread up and down the Pomeroon River. Rural farming families on the Pomeroon have been producing and selling furniture and handicrafts within Guyana for at least fifty years The nibbi cottage industry grew out of the efforts of some of the Pomeroon River families to expand their business. The relatively easy and rapid access from the town of Charity (on the lower Pomeroon River) to Georgetown is a distinct economic advantage for communities in the region (Fig. 1.4). Nibbi and kufa are not commercial forest products in other regions (where they are present) because the difficulty and expense of transportation are prohibitive.

Entrepreneurs first began bringing raw materials and furniture to Georgetown for local marketing and export to the Caribbean in the mid 1970's. A thriving market now exists in Georgetown for nibbi-based crafts and furniture. Tourists and local Guyanese are both common customers. In addition, investment in production of export-quality furniture has greatly increased. The Guyana Forestry Commission reported nibbi product exports worth only US $\$ 137,120$ in 1996 , but this is certainly an underestimate. 


\section{Chapter II. NATURAL Distribution, Growth, AND ANatomy of NibBi}

\subsection{INTRODUCTION}

Although many people in Guyana believe that there is an endless supply of nibbi in the forest, roots are often scarce close to villages. The depletion of Heteropsis roots due to overharvest has been observed in the rainforests of Peru (Salick 1992) and Ecuador (B. Bennett, pers. comm.). If nibbi is to be managed as an ecologically sustainable forest product, harvesting must be based on a biological understanding of $H$. flexuosa in it's forest environment. Most people involved in the nibbi furniture trade, including indigenous harvesters, know very little about $H$. flexuosa as a living, aerial-root-producing plant. Traditional indigenous knowledge about nibbi is valuable, but may not be applicable to higher intensity commercial extraction.

My objective in this chapter is to provide baseline biological information about $H$. flexuosa useful for scientific understanding, inventory, and the development of management plans (including the potential for sustainable harvest and cultivation). Although I did not determine the yearly production of nibbi root product, I measured growth and maturation rates as an initial step. In addition, I examined root anatomy to define general biological characteristics of the "product" and to explain the exceptional strength and flexibility of nibbi. These data are useful in understanding root maturation, guiding the processing and storage of roots (quality control), understanding the furniture design potential of nibbi, and for quantitative comparison with other known or potential forest fiber plants. 
This study is the first to provide quantitiative field data on $H$. flexuosa in Guyana. I examined $H$. flexuosa only in areas where there is an adequate abundance for commercial harvest and did not attempt to document overall landscape patterns.

\subsection{METHODS}

A) RESEARCH AREAS

I conducted fieldwork from October 1995 to August 1996 at two lowland rainforest research areas, one at Burahara Creek, Manawarin in the North-West District of Guyana and the other at the Iwokrama International Rainforest Reserve in south-central Guyana (Figs. 1.5 and 1.6).

\section{B) PLOTS AND HABITAT DEFINITION}

To study the natural distribution of $H$. flexuosa within forest habitats, my assistants and I established 700.1 ha $(20 \mathrm{~m} \times 50 \mathrm{~m})$ plots at the Manawarin and Iwokrama research sites (Table 2.1). I defined five habitat types, based primarily on a drainage gradient, following the methodology of ter Steege (1996) for similar forests at Mabura Hill, Guyana. The well-drained, steep slope mixed forest habitat of this study were occupied by the Greenheart forest type of Davis and Richards (1933). The well-drained (gentle slope and ridges) and poorly-drained (hill foot) habitats of this study represent variation in

moisture gradient within the mixed forest type. My riparian, alluvial habitat equates with 
the Mora forest type, but Mora forest is also seen intergrading with poorly drained and inundated habitats. At Iwokrama, I excluded several surveyed areas from the study where H. flexuosa was completely lacking, but I discuss those habitats below.

Our team established the 0.1 ha plots along transects, using a random stratified sample method. For each transect, we started from a non-random point (with at least some colonized host trees present) and chose between eight and thirteen plots. Plots were separated by randomly-determined distances to avoid sampling errors due to the patchy distribution of $H$. flexuosa (Siebert 1993). If a plot delineation included two habitat types, our team moved forward until a more homogenous area was encompassed. We used two 50 meter measuring tapes and a compass to delineate plots, marking corners and midway points with red flagging and aluminum tags. I chose a $20 \times 50 \mathrm{~m}$ plot size because I found it to be the most efficient, providing an area appropriately matched to the scale of $H$. flexiosa population clusters and convenient for 2-4 persons to survey. To study $H$. flexuosa growth rates and root anatomy, I marked or collected plants on host trees within un-delineated experimental areas and within 0.1 ha plots at the Manawarin and Iwokrama research sites. 
Table 2.1 No. plots in habitats at Iwokrama and Manawarin research areas

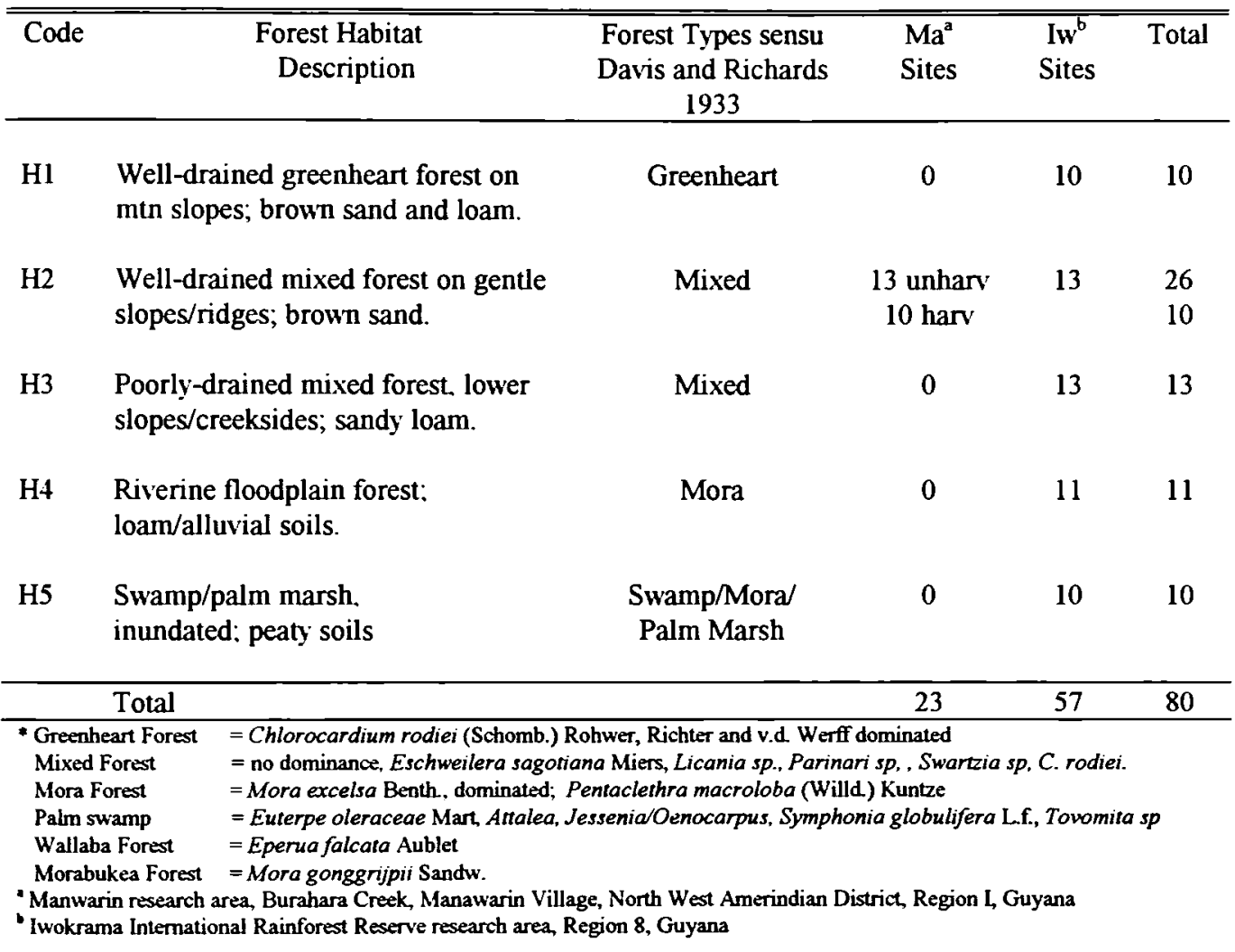

Table 2.2 Parameters for qualitative data

\begin{tabular}{llllc}
\hline \hline $\begin{array}{l}\text { Class } \\
\text { codes }\end{array}$ & Host zone & $\begin{array}{l}\text { Presence of non-H. flexuosa } \\
\text { climbing species }\end{array}$ & Light intensity & $\begin{array}{l}\text { No. absorbing } \\
\text { roots }\end{array}$ \\
\hline I & tree base to $1 \mathrm{~m}$ & no presence & full sun/gap & $1-5$ \\
II & lower half of trunk & few $(1-2$ spp./1-5 roots) & partial direct sun & $6-10$ \\
III & upper half of trunk & abundant (>2 spp./ $>5$ roots) & partial shade & $11-15$ \\
IV & lower crown & & full shade & $16-20$ \\
V & middle crown & & & $>21$ \\
VI & outer crown & & & \\
\hline
\end{tabular}




\section{C) METHODS: NATURAL DISTRIBUTION AND GROWTH}

\section{MACRO-HABITAT: FOREST COLONIZATION DENSITY}

To quantify colonization density in different habitats, I counted all trees $(\geq 10 \mathrm{~cm}$ $\mathrm{dbh}$ ) within plots and determined the number of these trees occupied by one or more mature clusters of $H$. flexuosa. I recorded only presence/absence due to the difficulty of distinguishing between genets and their associated ramets (Ch. 1.1). Shrubs and small trees ( $\leq 10 \mathrm{~cm} \mathrm{dbh)} \mathrm{rarely} \mathrm{served} \mathrm{as} \mathrm{a} \mathrm{substrate} \mathrm{for} \mathrm{colonization} \mathrm{(probably} \mathrm{due} \mathrm{to} \mathrm{their}$ low stature) and were not included in the inventory.

\section{MICRO-HABITAT: HOST TREE}

H. flexıosa mature clusters occur within specific environmental and spacial parameters on host trees. To make an initial assessment of the micro-habitat most often occupied by $H$. flexuosa, I recorded the light regime, host zone, and proximity of climbing non-Heteropsis plants, using qualitative classes (Table 2.2). For all of the variables, I used binoculars from the ground to observe the host tree position of the most robust $H$. flexuosa mature clusters. For vertical stratification, I divided each host tree into six height zones using a schematic drawing (Fig 2.1, following ter Steege and Cornelissen 1989). In addition, I recorded host tree diameters at breast height $(1.37 \mathrm{~m})$ and identified host trees when possible, without collecting voucher specimens. I did not measure or identify non-host trees within plots. 


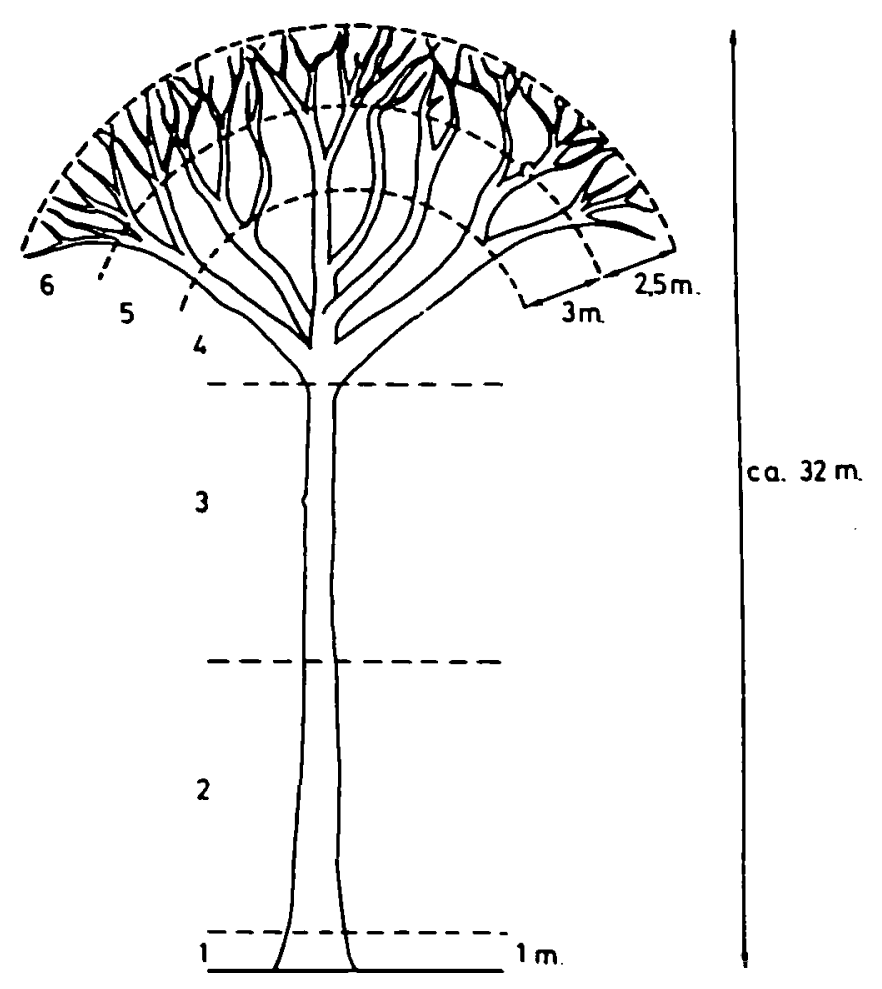

Figure 2.1 Diagram of host tree zonation (after ter Steege et. al. 1996) 


\section{GROWTH AND MORTALITY}

To study the natural growth rates, maturation and survivorship of $H$. flexuosa stems and absorbing roots, I marked plants at the Manawarin and Iwokrama sites in mid-February, 1996 and then returned after six months to re-measure and assess changes. I marked 116 individuals in the seedling size-class, 41 individuals in the juvenile size-class, and 20 mature clusters (Fig. 1.1) by driving a tagged aluminum nail into host trees adjacent to apical meristems. I climbed trees with climbing spikes and a harness when necessary to access the plants. I took great care not to crush plants or roots on the host trunk, although there was some unavoidable damage.

I marked 56 young, terrestrially-connected roots to observe maturation and 11 newly descending roots to observe growth rates and maturation. For new roots growing along the trunk, I measured the width and placed a nail adjacent to the apical meristem. I marked the new descending "drop" roots with flagging tape $40 \mathrm{~cm}$ above the root apical meristem and with a machete cut on the host trunk. 


\section{D) METHODS: ABSORBING ROOT ANATOMY}

\section{ANATOMICAL FIELD COLLECTIONS}

I collected samples from 30 absorbing roots at different stages of maturity and at different vertical levels. Root specimens were each cut in $1-5 \mathrm{~cm}$ lengths, labeled and preserved in FAA. Voucher specimens were deposited at the Smithsonian Insititution's National Herbarium (SI) in Washington, D.C (BH 4640, 5050, 5052, 5053, 5054). When all specimens have been determined duplicates will be sent to the University of Guyana herbarium, Florida International University, Missouri Botanical Garden, and Fairchild Tropical Garden.

\section{ANATOMICAL LABWORK}

Microtechnique was undertaken at the Fairchild Tropical Garden research laboratories with Dr. Jack Fisher in Miami, Florida. I sectioned roots by hand with a razor and stained specimens with $5 \%$ aqueous solution of Tuolidine Blue for lignin and $5 \%$ solution of Sudan IV in $95 \%$ alcohol for suberin. I observed specimens with a dissecting microscope and with a compound microscope, drawing structures with a camera lucida attachment. I documented root anatomy at different stages of differentiation, with an emphasis on older, heavily lignified roots. Due to their extreme hardness, it was difficult to obtain thin sections of mature roots. 
To observe and compare entire individual fibers and other cells, I removed samples from four cross-sectional zones by cutting longitudinal slices. The zones include the outer cortex, the circumstelar sclerenchymatous ring, the peripheral stele, and the nonperipheral stele (Fig. 2.2). I immersed samples in vials with Jeffrey's formula (10\% aqueous nitric acid and $10 \%$ aqueous chromic acid) and placed them in a $60^{\circ}$ oven for 1-24 hours. A hand-cranked centrifuge was used to concentrate macerated cells in test-tubes. I then randomly selected portions of macerated cell concentrate from test-tubes representing each root zone.

The process of random fiber sampling and measurement is as follows:

1) I emptied the macerated contents of each test-tube into a beaker and stirred rapidly, siphoning off a small portion of the concentrate with a pipette and placing it on a slide;

2) I siphoned off two more small portions without stirring the mixture, one from the bottom of the beaker and another from higher up, mixing them together with the step 1 sample;

3) I spread the cells out on the slide, separating clumps and observing cells at various magnifications with a light microscope to distinguish cell types; 
4) I made three parallel "transect-line" sweeps, recording observations for every intact and unobscured fiber passing under the crosshairs of the ocular lens. The variables of length and width (at widest point) were recorded for 60 fibers in each zone. In addition, I documented the diameter of the lumen and cell wall, cell appearance and texture, fiber cell end shapes, and the presence or absence of crystals for a smaller number of fibers.

5) Because many of the fibers were bent, I made drawings on paper with the camera lucida attachment and then measured the drawings with a metric ruler.

I compared fiber sample ( $n=60$ ) observations from the four cross-sectional root zones with a one way ANOVA and Tukey's HSD post-hoc test. 


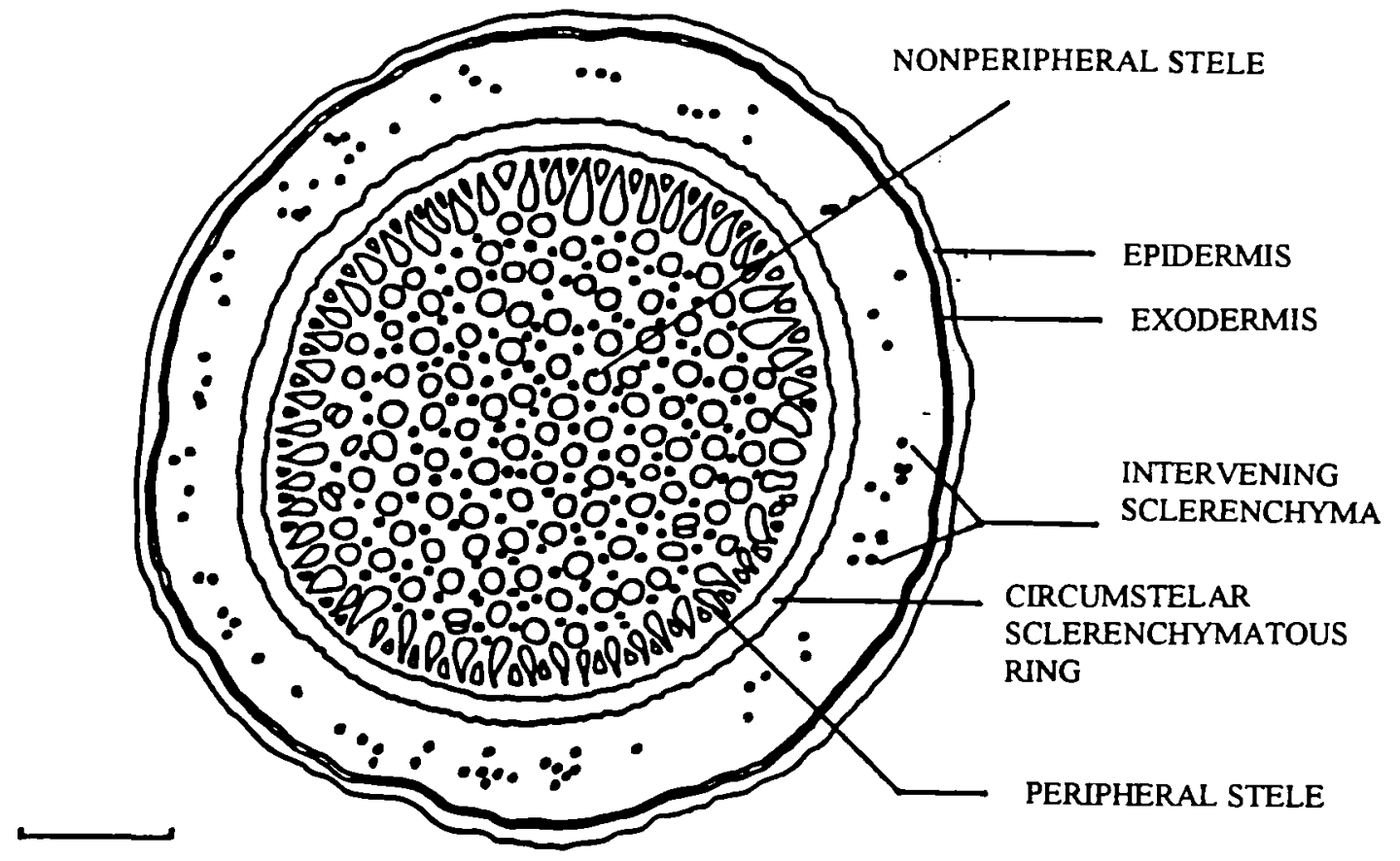

Figure 2.2 Transverse-section of mature absorbing root of Heteropsis flexuosa. Scale bar $=1 \mathrm{~mm}$. 


\subsection{RESULTS AND DISCUSSION}

\section{A) RESULTS I: NATURAL DISTRIBUTION AND GROWTH}

\section{MACRO-HABITAT: FOREST COLONIZATION DENSITY}

The five study habitats at Iwokrama were not significantly different in tree density per 0.1 ha (ANOVA, $P>0.05$ ), ranging from $57.8 \pm 3.5 \mathrm{SE}$ on riverine alluvial soils (Mora Forest) to $72.0 \pm 5.0 \mathrm{SE}$ on steep bouldery slopes at Iwokrama. I found a range of $6.1 \pm 1.1 \mathrm{SE}$ to $23.2 \pm 2.1 \mathrm{SE}$ trees $(\geq 10 \mathrm{~cm} \mathrm{dbh})$ per 0.1 ha colonized by mature stems of Heteropsis flexuosa (Table 2.3). The percent of colonized trees to all trees in plots ranged from 9 to $41 \%$. H. flexuosa colonization density varied significantly among the habitats (ANOVA, $\mathrm{P}<0.001$ ).

The $\mathrm{H} 2, \mathrm{H} 3$, and $\mathrm{H} 4$ habitats form a distinct group, with significantly higher colonization densities than the $\mathrm{Hl}$ and $\mathrm{H} 5$ habitats (HSD post-hoc test). I excluded the $\mathrm{Hl}$ and $\mathrm{H} 5$ habitats from the remaining analyses due to their low densities of $H$. flexuosa colonization (and virtual absence of nibbi roots). The total number of trees and the number of colonized trees per 0.1 ha was significantly different $(t$ test, $P<0.05)$ between $\mathrm{H} 2$ habitat at the Manawarin $(19.3 \pm 2.1)$ and Iwokrama $(29.7 \pm 2.1) \mathrm{SE}$ sites. But the percentage of colonization was not significantly different, with $39 \%$ at Manawarin and $36 \%$ at Iwokrama ( $t$ test, $P>0.05$ ). 
Within Iwokrama, I found no Heteropsis populations at Pakutau Hills on laterite "ironstone" hills, within white sand Wallaba forests, or within seasonal forests at the southern boundary. I found very low densities of nibbi west of the Burro-Burro River, in alternating mixed forest and swamp habitats (Fig 1.6).

\section{MICRO-HABITAT: HOST TREE}

Host zonation and light exposure. Heteropsis flexuosa mature clusters occured nonrandomly within host zones III (23\%) and IV (77\%), on the upper bole or lowest branching point of host trees (Fig 2.1, Table 2.4; $\chi^{2}, \mathrm{P}<0.001$ ). In addition, mature clusters occured significantly more often in partial shade $(33 \%)$ or partial sun $(55 \%)$ than in other conditions (Table $2.4 ; \chi^{2}, \mathrm{P}<0.001$ ). I observed mature clusters in full shade on only $8 \%$ of host trees.

Presence of other climbing species. H. flexuosa occurred in isolation, without other large climbers, on $79 \%$ of host trees, with a few associated species on $17 \%$, and in proximity to many other species in only $5 \%$ of observations (Table 2.5 ).

Host tree diameter and host species identification. Considering host tree dbh in all plots, $40 \%$ were in the $10-20 \mathrm{~cm}$ class, $34 \%$ in the $20-30 \mathrm{~cm}$ class, $19 \%$ in the $30-40 \mathrm{~cm}$ class, and $6 \%$ in the $60 \mathrm{~cm}$ and greater class (Table 2.5). The mean host tree $\mathrm{dbh}$ was $32 \mathrm{~cm}$. In addition, I made brief taxonomic assessments of host trees encountered within plots (Appendix III). $27 \%$ of the host trees were identified to genus, $40 \%$ to species, and $1 \%$ 
were given local names only. $30 \%$ of the host trees were not identified. Because I did not measure or identify non-host trees within plots, I could not determine an overall forest preference for host tree characteristics.

\section{GROWTH AND MORTALITY}

Juvenile and mature shoots. Forty-three percent of individuals in the seedling size-class $(n=116)$ exhibited positive growth from the shoot apical meristem, $35 \%$ showed no signs of growth and $21 \%$ did not survive after six months (Table 2.6). For individuals in the juvenile size-class ( $n=41), 39 \%$ exhibited positive growth, $50 \%$ did not grow, and there was $10 \%$ mortality. In addition, I found that $35 \%$ of mature clusters $(n=20)$ grew, $55 \%$ did not grow, and $5 \%$ died, most of the deaths resulting from tree falls.

Those seedling size-class individuals exhibiting growth extended a mean $10.4 \mathrm{~cm}$ in six months or $1.7 \mathrm{~cm}$ per month. Juveniles grew the furthest, extending a mean $18.8 \mathrm{~cm}$ in six months or $3.1 \mathrm{~cm}$ per month. I documented one juvenile individual that had "bolted" 66 $\mathrm{cm}$ up a host tree trunk within six months. Of the 7 mature stems that exhibited upwards growth, the rate was a mean $5.4 \mathrm{~cm}$ in six months or $0.9 \mathrm{~cm}$ per month.

Roots. In absorbing root growth experiments, $52 \%$ of young roots $(n=67)$ increased in maturity in 6 months, $38 \%$ showed no change and $9 \%$ died (Table 2.6). Newly emergent roots $(n=11)$ grew a mean $156.1 \mathrm{~cm}$ in 6 months or $26.0 \mathrm{~cm}$ per month. 
In a separate experiment, the maturation of eleven young roots on one host tree were documented at the Manawarin site. Six of the roots were not yet in contact with the soil, two were in soil contact but not established, and three were recently established in the soil. Five out of the eleven roots matured to a harvestable or almost harvestable state within six months 
Table 2.3 No. colonized trees $\geq 10 \mathrm{~cm}$ dbh per 0.1 ha

\begin{tabular}{|c|c|c|c|c|c|}
\hline $\begin{array}{c}\text { Forest } \\
\mathrm{Hab}\end{array}$ & $\begin{array}{c}\text { Research } \\
\text { Area }^{\mathrm{a}}\end{array}$ & $\begin{array}{c}\mathrm{N} \\
\text { plots }\end{array}$ & $\begin{array}{l}\text { Mean no. } \\
\text { colonized } \\
\text { trees } 0.1 \text { ha }\end{array}$ & $\begin{array}{c}\text { Mean \% } \\
\text { colonized } \\
\text { trees }\end{array}$ & $\begin{array}{l}\text { Density: all trees } \\
/ 0.1 \text { ha }\end{array}$ \\
\hline $\mathrm{Hl}$ & I & 10 & $6.09(1.1)$ & .11 & $72.0(5.0)$ \\
\hline $\mathrm{H} 2$ & $\mathrm{M} / \mathrm{I}$ & 25 & $23.1(1.8)$ & .37 & $60.2(3.3)$ \\
\hline $\mathrm{H} 2$ & M only & 13 & $19.3(1.6)$ & .39 & $51.8(3.5)$ \\
\hline $\mathrm{H} 2$ & I only & 13 & $29.7(2.8)$ & & $66.0(3.1)$ \\
\hline $\mathrm{H} 3$ & I & 13 & $17.9(2.0)$ & .28 & $67.1(4.2)$ \\
\hline $\mathrm{H} 4$ & I & 11 & $23.2(2.1)$ & .41 & $57.8(3.5)$ \\
\hline H5 & I & 10 & $7.1(1.4)$ & .09 & $69.0(4.2)$ \\
\hline
\end{tabular}

Total 70

- Manurin research area, Burahara Creek, Manawarin Village, North West Amerindian District, Region L, Guyana

- Iwokrama International Rainforest Reserve research area, Region 8, Guyana

()$= \pm S E$

Table 2.4 Association of $H$. flexuosa with light intensity and vertical host zones

\begin{tabular}{lccc}
\hline \hline Light Regime & $\begin{array}{c}\text { No. host trees } \\
\text { obsered }\end{array}$ & Host Zone & $\begin{array}{c}\text { No. host tree } \\
\text { obsered }\end{array}$ \\
\hline & & I: base $-1 \mathrm{~m}$ & \\
full shade & 81 & II: trunk $1-10 \mathrm{~m}$ & 0 \\
partial shade & 240 & III: trunk 10-20m & 5 \\
partial direct sun & 339 & IV: lower canopy & 231 \\
full sun'gap & 36 & V: middle canopy & 0 \\
& & VI: outer canopy & 0 \\
\hline Total & 1026 & & 1026 \\
\hline
\end{tabular}


Table 2.5 Association of $H$. flexuosa with climbing plants and host dbh

\begin{tabular}{|c|c|c|c|c|c|}
\hline Association & $\begin{array}{l}\text { No. Host } \\
\text { Trees }\end{array}$ & $\%$ & $\begin{array}{l}\text { DBH class } \\
(\mathrm{cm})\end{array}$ & $\begin{array}{l}\text { No. Host } \\
\text { Trees }\end{array}$ & $\%$ \\
\hline Strong association & 51 & 5 & $10-20$ & 410 & 40 \\
\hline Medium association & 174 & 17 & $20-40$ & 349 & 34 \\
\hline \multirow{2}{*}{$\begin{array}{l}\text { Weak association: no } \\
\text { presence }\end{array}$} & 810 & 79 & $40-60$ & 195 & 19 \\
\hline & & & $>60$ & 72 & 7 \\
\hline Total & 1026 & & & 1026 & \\
\hline
\end{tabular}

Table 2.6 Growth, survival, and mortality of $H$. flexuosa stems and roots

\begin{tabular}{|c|c|c|c|c|c|c|}
\hline Size Class & $\mathrm{N}$ & $\begin{array}{l}\text { No. with } \\
\text { growth }\end{array}$ & $\begin{array}{c}\text { mean cm growth/ } \\
6 \text { mos }\end{array}$ & $\begin{array}{c}\text { est.cm } \\
\text { growth/ } \\
\text { mo }\end{array}$ & $\begin{array}{l}\text { No. w/o } \\
\text { growth }\end{array}$ & $\begin{array}{c}\text { No. } \\
\text { mortality }\end{array}$ \\
\hline Seedlings & 116 & $43 \%$ & $10.4(1.6)$ & 1.7 & $35 \%$ & $21 \%$ \\
\hline Juveniles & 41 & $39 \%$ & $18.8(2.6)$ & 3.1 & $50 \%$ & $10 \%$ \\
\hline Mature cluster & 20 & $35 \%$ & $5.4(1.1)$ & 0.9 & $60 \%$ & $5 \%$ \\
\hline $\begin{array}{l}\text { Young terrestrial } \\
\text { roots }\end{array}$ & 67 & $\begin{array}{c}52 \% \\
\text { maturation }\end{array}$ & N/A & N/A & $38 \%$ & $9 \%$ \\
\hline $\begin{array}{l}\text { Unestablished } \\
\text { drop roots }\end{array}$ & 11 & $100 \%$ & $156.1(62.4)$ & 26.0 & $0 \%$ & $9 \%$ \\
\hline
\end{tabular}




\section{B) DISCUSSION I: NATURAL DISTRIBUTION AND GROWTH}

Colonization Density. Nibbi plants were prolific colonizers in Iwokrama mixed forest/well-drained (H2), mixed forest/poorly-drained (H3), and Mora forest/riparian (H4) habitats, although with a patchy distribution. Considering the three habitats together, a mean $35 \%$ of trees $(\geq 10 \mathrm{~cm} \mathrm{dbh})$ were colonized per plot (min. $11 \%-\max .80 \%)$. Compared with the few other studies where colonization data is recorded, colonization density of $H$. flexwosa is relatively high for a single species. Kelly (1985) recorded a mean $30-45 \%$ of trees $(\geq 10 \mathrm{~cm} \mathrm{dbh})$ in Trinidad lowland rainforest plots infested by any rootclimbing aroid species. Talley et. al. (1996) recorded $46 \%$ of tree species ( $\geq 10 \mathrm{~cm} \mathrm{dbh})$ colonized by either of two non-aroid root-climbing species in Australian rainforest. Primary hemi-epiphytes occupied $10-15 \%$ of neotropical lowland rainforest canopy trees in one study (Putz and Holbrook 1986) and 9.8\% in another study (Todzia 1986).

I found minimal nibbi colonization in well-drained Greenheart forests on bouldery slopes (H1) and inundated/swamp habitats (H5). These two habitats represent the drainage extremes among my study habitats. As mentioned above, I observed that white-sand Wallaba forests and seasonal forests (savannah/forest ecotone) in the Iwokrama area lack H. flexuosa. Wallaba forest is the least humid, most nutrient-poor, and most rapidly draining of the lowland rain forest types (Richards and Davis 1933, Fanshawe 1952, ter Steege 1995). Seasonal forest, regardless of its soil and canopy cover, experiences long periods of dryness. It appears that $H$. flexuosa plants require humid habitats with moderate drainage. 
In addition, there are forest areas in Guyana where $H$. flexuosa is rare or absent, even though the habitat appears ideally suited. T. van Andel, a botanist working at Kariako Village on the Barama River (North-West District), found no $H$. flexuosa populations in her study area. She observed that the Carib people of Kariako use the roots of a cyclanth (Evodianthus funifer $\mathrm{L}$.) for the same purposes and call it nibbi.

My initial results show a large difference between unharvested H2 (mixed forest/welldrained) habitat of the north and the more remote south in the total number of trees. The opportunities for colonization are less at the Manawarin site. It is interesting, though, that the same percent of trees were occupied at the two sites. Future studies should collect data in non-H2 habitats at Manawarin for further comparison.

Host zonation, light exposure, and plant associations. Available light and humidity for epiphytes and hemi-epiphytes is directly associated with position on the host (Benzing 1986, ter Steege and Cornellisen 1989). Plants at tree bases or low on the trunk experience the lowest light levels (PFD) and the highest humidity. Plants in the uppermost canopy receive strong sunlight and sporadic rainfall, being alternately dessicated and inundated. The most robust $H$. flexuosa mature clusters occured preferentially on the upper trunk or lowest branches of host trees. These positions correlate with the partial shade/partial light preference also documented for mature clusters. I have never observed H. flexuosa stems extending into the strong light conditions of the upper canopy (zone VI) 
or establishing mature clusters low on the host trunk. In instances when I observed plants exposed to direct sunlight (i.e. tree falls) they appeared stressed, with yellowing of leaves.

Mature clusters were rarely seen in close proximity to other climbing plants and this is also in part a function of host position. The "preferred" upper trunk position of mature $H$.

flexuosa is well below the climbers and epiphytes of the upper canopy and above the rootclimbers of the lower trunk. The few close associations with other plants usually occurred in zone IV at the first host branching point.

Because root-climbing plants such as Heteropsis are not limited by the trunk size of potential hosts (Hegarty 1991), the host dbh distribution of $H$. flexuosa may simply reflect the natural tree dbh distribution in habitats. In addition, it is possible that the more commonly colonized tree species are simply the more abundant species in the forest. The species colonized more than 10 times (Appendix III) are all common in Guyana's lowland rainforests. Host dbh and species preference cannot be fully documented without data on non-host trees. In Trinidad, Simmonds (1950) found no association of aroid species with particular tree species in Mora forest. Ideally, future studies will quantify the degree of colonization per host tree (Talley et. al. 1996) to see if older/larger trees are colonized more often. In the field I noted that large emergents rarely hosted $H$. flexuosa.

Host dependent plant colonization may be affected by host bark characteristics including texture, turnover, porosity, $\mathrm{pH}$, nutrient content, toxins, and turnover (ter Steege and 
Cornellisen 1989; Talley 1996). I did not document micro-bark characteristics in this study, but I noted that Greenheart (Chlorocardium rodiei) rarely served as a host for $H$. flexuosa. Greenheart trees have an exfoliating bark that commonly sheds off climbers and epiphytes (ter Steege and Cornellisen 1989). Palms also rarely support $H$. flexuosa. The lack of climbing plants on palms in general has been noted by other authors (Putz 1984)

Growth and mortality. Care must be taken in making extrapolations from growth rate data collected over the course of six months because is a relatively short length of time for understory tropical plants. My mean growth rates probably overestimate yearly growth rates because (assuming the majority of growth occurs during the rainy season) the time interval between field measurements included Guyana's major rainy months and excluded most of the drier months. The plants and plots documented in this study are well marked and could be re-visited in the future to record longer-term data.

The large percentage of stems in all stem classes without any visible growth in six months (35-60\%) and the small distance covered by growing stems, suggests that $H$. flexuosa grows slowly. But, as I noted in the results section, juveniles can grow in sudden bursts. Perhaps most young $H$. flexuosa stems have difficulty accumulating enough resources in low light conditions to grow rapidly upwards. In addition, there may be limiting environmental factors (e.g.: herbivory) that were outside the scope of this study. 
Using the growth data on stem size-classes and roots (Table 2.6), I estimated several potential times required for an $H$. flexuosa seedling to grow and produce mature absorbing roots. For the purpose of discussion, I made assumptions on growth rates and the total distance covered. My assumptions are: 1 . growth rates are constant for a given size class; 2 . the plant will climb at a ninety degree angle for $0.5 \mathrm{~m}$ as a seedling and then proceed $14.5 \mathrm{~m}$ farther as a juvenile; and 3. the plant will establish a mature cluster at 15 $\mathrm{m}$ and immediately issue robust absorbing roots that grow $15 \mathrm{~m}$ to the ground (Figs.1.1, $1.2)$

At a growth rate of $1.7 \mathrm{~cm}$ per month (Table 2.6 ) the seedling stage would require about 2.5 years to grow $50 \mathrm{~cm}$. When the plant changes to the juvenile stage, the growth rate would increase to $3.1 \mathrm{~cm}$ per month $(37.2 \mathrm{~cm} / \mathrm{yr})$. If this growth rate remained constant, it would require 55 years for the juvenile to reach the $15 \mathrm{~m}$ level. A robust root issued from the plant (growing at $26 \mathrm{~cm}$ per month, Table 2.6) would require approximately 5 years to reach the soil and, once there, could mature in as little as six months. Conservatively allowing the root a year to mature, it will have taken 61 years (!) for the seedling to grow and produce robust aerial absorbing roots. But, this statistic is likely an overestimate because changes in growth rate at higher levels on the host are not taken into account. If a juvenile stem grew 3.1 centimeters per month for only 2.5 years, and then increased growth to $8.33 \mathrm{~cm}$ per month $(1 \mathrm{~m} / \mathrm{yr})$, it would reach 15 meters in approximately 18.5 years and produce roots within 24.5 years. Simmonds (1950) cites an average growth rate of one half meter per year for root-climbing aroids, based only on 
ground measurements. Considering the time frame of maturation for other non-cultivated tropical plants used as products, particularly timber species, even the 61 year estimated turnover rate is relatively rapid. 


\section{C) RESULTS II: ABSORBING ROOT ANATOMY}

\section{MATURE ABSORBING ROOT IN CROSS-SECTION}

Mature Heteropsis flexuosa absorbing roots possess a periderm, epidermis, cortex, and stele. In cross-section, the roots are circular to elliptical and range from 3 to $9 \mathrm{~mm}$ in diameter (refer to Fig. 2.3). Approximately $30 \%$ of cross-sectional area in most roots is epidermis and cortex and $70 \%$ is stele (using $\pi r^{2}$ )

In cross-section, I observed a one-cell thick exodermis below the epidermis with a thick common wall between these two tissues. An endodermis is present, made up of sclerenchyma cells with evenly thickened walls. Between the exodermis and endodermis I found three distinct cortical regions. The first or outermost region is a wide band containing oblong to elongate parenchyma cells with long axes parallel to the root length. Single and clustered sclerenchyma cells are scattered throughout this region and more densely in the periphery (intervening sclerenchyma). Cells in the peripheral cortex are smallest, increasing in size centripetally.

The second zone is a circumstelar sclerenchymatous ring. The ring is made up entirely of short fibers and is 5 to 6 cells thick $(0.16 \mathrm{~mm})$ in cross-section. Broad sclerenchymatous rings are a common feature of epiphytic monocot roots and most likely function in protection and mechanical support (Wilder 1986a). The third distinct cortical zone in $H$. 
flexuosa is a few rows of parenchyma cells separating the sclerenchymatous fiber ring from the endodermis.

Within the stele I observed pericycle, vascular tissues, xylem sheaths, and interfascicular tissue in cross-section (Fig. 2.3). Wilder (1986b) refers to the discrete groups of tracheary and sieve elements in Cyclanthaceae roots as fascicles and I adopt his terminology here. Near the edge of the stele peripheral xylem fascicles and phloem fascicles alternate with one another, forming a polyarch ring. The most peripheral, narrower tracheary elements and sieve elements here comprise the protophloem and protoxylem. The pericycle is narrow and composed of one or more parenchyma cells, merging with peripheral fascicles. Discrete metaxylem fascicles with one to two elements and metaphloem fascicles with many elements are distributed evenly throughout the nonperipheral stele (Fig. 2.3). Esau (1966), noted that this type of root structure with "vessels and phloem strands...scattered throughout the central part of the vascular cylinder" (in Monstera) is relatively complex for monocots.

At maturity, the stele is densely packed with fibers. Nonperipheral xylem and phloem fascicles are clearly encircled by fibers in cross-section, forming "interfascicular fiber aggregates" (Wilder 1992) (Fig. 2.3). The aggregates generally occur in an oblong pattern around each fascicle, with a few cells on one side and many cells on the opposite side. Fiber aggregates occur in a crescent pattern on the centripetal side of peripheral xylem fascicles and phloem fascicles. 
An "interfascicular intrusive network" (Wilder 1992) of parenchyma cells separate the fiber aggregates with their enclosed vascular fascicles. Cells of the interfascicular network are variable in size, cell wall thickness, and sclerification, but remain much thinner-walled than the fibers in the stele. At full maturity, the intrusive network is highly reduced and fibers are dominant, with adjoining fiber aggregates widening and growing into one other (Fig. 2.3).

In addition, I observed xylem sheaths encircling nonperipheral xylem fascicles and centripetal portions of peripheral xylem fascicles. The sheath cells are uniseriate, thinwalled in comparison to fibers, conspicuously pitted, and tightly appressed to xylary elements. 

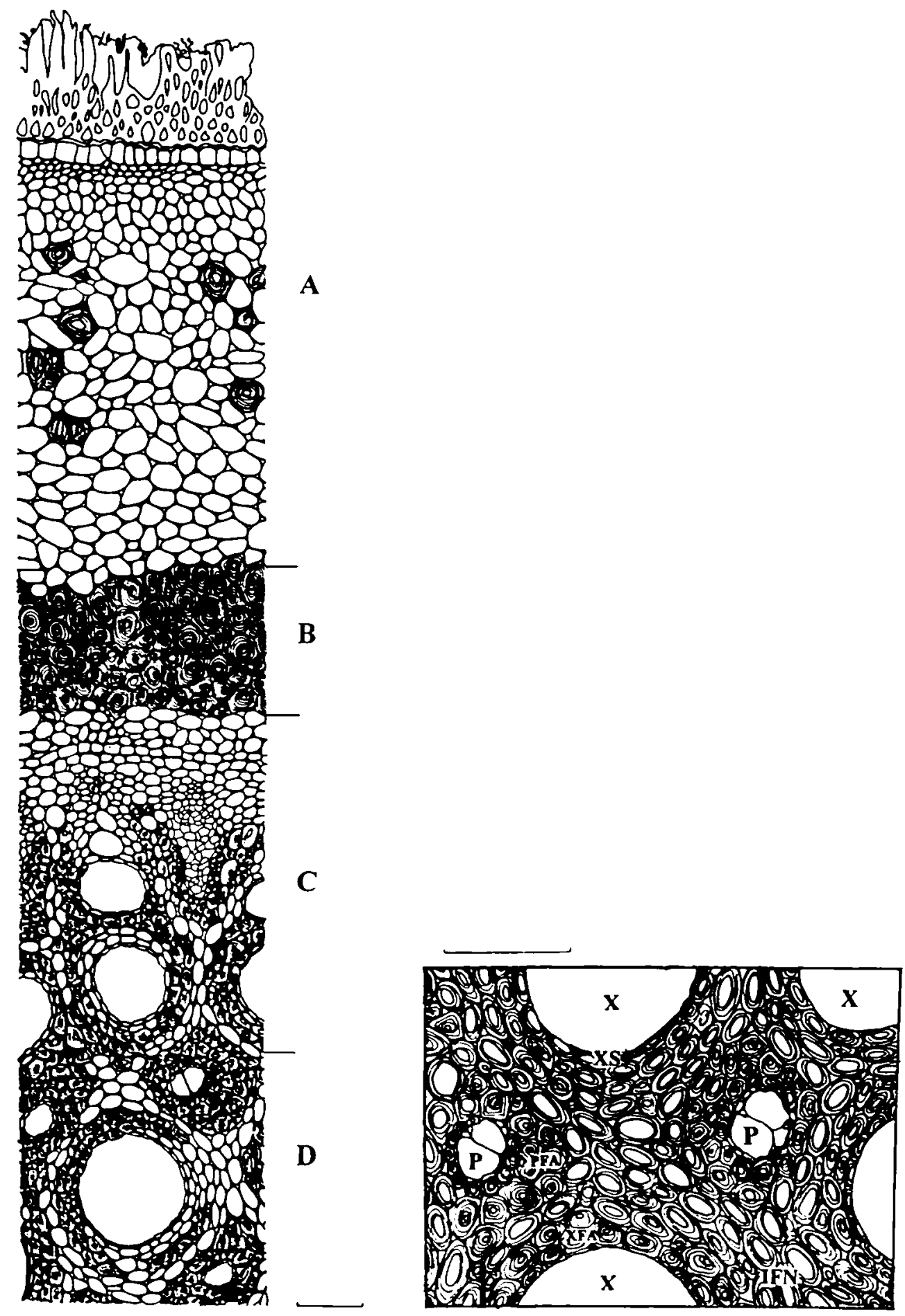

Figure 2.3 H. flexuosa absorbing root transverse-section including details of nonperipheral stele. Zone $\mathrm{A}=$ outer cortex; Zone $\mathrm{B}$ = circumstelar sclerenchymatous ring; Zone $\mathrm{C}=$ peripheral stele; Zone $D=$ nonperipheral stele. $X=x y l e m$ element; $P=$ phloem element; $X F A=x y l e m$ fiber aggregate; PFA = phloem fiber aggregate; $X S=$ xylem sheath; IFN = Interfascicular network Scale bar $=100 \mu \mathrm{m}$ 

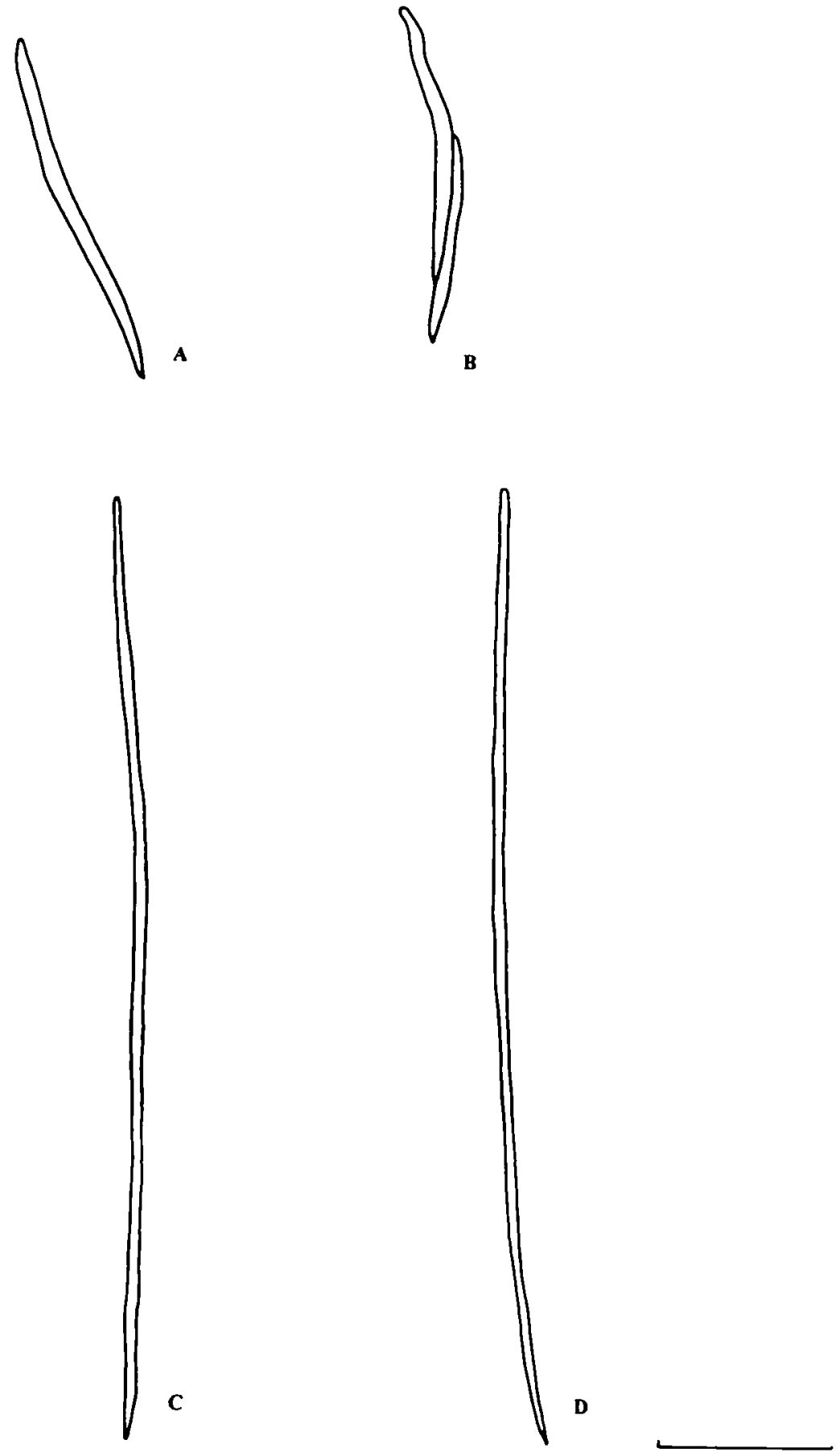

Figure 2.4 Fibers obtained from four distinct cross-sectional zones within one mature $H$. flexwosa absorbing root. Zone $\mathrm{A}=$ outer cortex; Zone $\mathrm{B}=$ circumstelar sclerenchymatous ring: Zone $C=$ peripheral stele: $Z$ Zone $D=$ nonperipheral stele. Scale bar $=300 \mu \mathrm{m}$ 


\section{MACERATED FIBERS}

Zone A: Peripheral cortical fibers. Fibers in the outer cortex have a mean length of 566 $\mu \mathrm{m}$ (range 124-1019 $\mu \mathrm{m}$ ) and a mean width of $31 \mu \mathrm{m}$ (range 12-51 $\mu \mathrm{m}$ ) [Table 2.7, Fig.

2.4]. The mean diameter of the lumen is $4 \mu \mathrm{m}(\max =11 \mu \mathrm{m})$ or $15 \%(\max =29 \%)$ of the total fiber width. Fibers cell ends are usually tapered, bluntly pointed at one end and sharply pointed to rounded at the opposite end. In transverse section, the fibers are pentagonal or hexagonal and slightly rounded in outline. The fiber cell walls are of uniform thickness.

Zone B: Circumstellar sclerenchymatous ring. Fibers in the circumstellar sclerenchymatous ring have a mean length of $486 \mu \mathrm{m}$ (range 190-870 $\mu \mathrm{m}$ ) and a mean width of $22 \mu \mathrm{m}$ (range 9-36 $\mu \mathrm{m}$ ) [Table 2.7]. Fibers cell ends are tapering, often bent, bluntly pointed at one end and rounded at the other end. In transverse section the fibers are tightly packed with little visible intracellular space and no other cell types present. The cell walls are uniformly thickened with clearly visible laminated layers. The walls are also angular, four- to seven-sided, and with very small lumens.

Zone C: Peripheral stele. Fibers in the peripheral stele have a mean length of $1510 \mu \mathrm{m}$ (range 260-4278 $\mu \mathrm{m}$ ) and a mean width of $20 \mu \mathrm{m}$ (range 7-38 $\mu \mathrm{m}$ ) [Table 2.7]. The mean diameter of the lumen is $4 \mu \mathrm{m}(\max =13 \mu \mathrm{m})$ or $20 \%(\max =42 \%)$ of the total fiber width. Most macerated fibers appear straight and rigid, although some are flexible and 
curved under the microscope. Fibers cell ends are tapering, occasionally bent, bluntly to sharply pointed at one end and rounded to pointed at the opposite end. In transverse section the fibers are quadrangular to hexagonal and slightly rounded in outline. The cell walls are of uniform thickness and visibly laminated.

Zone D: Nonperipheral stele. Fibers in the nonperipheral stele appear identical to those in the peripheral stele, with a slight difference in dimensions. Nonperipheral fibers have a mean length of $1614 \mu \mathrm{m}$ (range $465-3278 \mu \mathrm{m}$ ) and a mean width of $21 \mu \mathrm{m}$ (range 8-43 $\mu \mathrm{m})$ [Table 2.7]. The mean diameter of the lumen is $3 \mu \mathrm{m}(\max =15.6 \mu \mathrm{m})$ or $15 \%(\max$ $=36 \%$ ) of the total fiber width.

\section{ANALYSIS}

Fibers from the four cross-sectional root zones differ for the variables length and width using a one way ANOVA test (Table 2.7, $\mathrm{P}<0.05$ ). In LSD post-hoc tests of length, the fiber populations form two groupings. A and B zone fibers are similar to one another and both shorter than $\mathrm{C}$ and $\mathrm{D}$ zone fibers, while $\mathrm{C}$ and $\mathrm{D}$ zone fibers are similar to one another. In LSD post-hoc tests for width, fibers from zones B, C, and D zone are similar to one another, all being narrower than A zone fibers.

Because there is no significant difference in length or width for fibers from zones $C$ and $D$, I pool them together in this analysis. Nonperipheral and peripheral fibers together have a mean length of $1562 \mu \mathrm{m}$ (range $718-4278 \mu \mathrm{m}$ ) and mean width of $20 \mu \mathrm{m}$ (range 6-43 
$\mu \mathrm{m}$ ). Intervening sclerenchyma fibers from the outer cortex (zone A) are slightly more than one third the length of fibers from zones $C$ and $D$, and, at $31 \mu \mathrm{m}$, are the widest fibers in the root. The fibers of the circumstelar sclerenchymatous zone are less than one third the length of of fibers from zones $\mathrm{C}$ and $\mathrm{D}$, and have approximately the same width.

Table 2.7 Size of fibers obtained from four distinct cross-sectional zones within a mature $H$. flexuosa absorbing root"

\begin{tabular}{lcccccc}
\hline \hline Root zone & \multicolumn{3}{c}{ Fiber length $(\mu \mathrm{m})$} & \multicolumn{3}{c}{ Fiber width $(\mu \mathrm{m})$} \\
& \multicolumn{2}{c}{$\mathrm{N}=60$} & $\mathrm{~N}=60$ \\
\hline A & $\mathbf{5 6 6}^{\mathrm{a}}$ & 172 & 1019 & $\mathbf{3 1}^{\mathrm{a}}$ & 8 & 51 \\
B & $486^{\mathrm{a}}$ & 160 & 870 & $22^{\mathrm{b}}$ & 7 & 36 \\
$\mathrm{C}$ & $1510^{\mathrm{b}}$ & 769 & 4278 & $20^{\mathrm{b}}$ & 6 & 38 \\
D & $1614^{\mathrm{b}}$ & 667 & 3278 & $21^{\mathrm{b}}$ & 7 & 43 \\
$\mathrm{C}+\mathrm{D}$ & 1562 & 718 & 4278 & 20 & 6 & 43 \\
\hline
\end{tabular}

Zone A = outer cortex; Zone B = circumstelar sclerenchymatous ring; Zone $\mathrm{C}=$ peripheral stele; Zone $\mathrm{D}=$ nonperipheral stele. Fiber length: ANOVA $\mathrm{F}=79.4, \mathrm{df}=236$. Fiber width: $\mathrm{F}=37.3 \mathrm{df}=236$. The results of post-hoc tests are indicated with superscript letters.

\section{D) DISCUSSION II: ABSORBING ROOT ANATOMY}

When nibbi is extracted from the forest, the root cortex is eventually discarded.

Only the stele, whole or longitudinally split, has the characteristic strength and flexibility that people find useful. In this section I consider the biological function of select 
anatomical tissues and the contribution of individual cells and structure to the physical characteristics of the root product (Refer to Fig. 2.3).

Epidermis. The epidermis is narrow and has no fibers, therefore this tissue is soft and has no potential use as a fiber product.

Outer cortex. The outer cortex consists of occasional sclereids (idioblasts) and fiber strands scattered through a matrix of unsclerified parenchyma. Because the pericortical fibers are short in comparison to fibers in the stele and occur singly or in small groups, they do not provide much strength.

Circumstelar Sclerenchymatous Ring. The circumstelar sclerenchymatous ring, consisting solely of densely packed fibers, is much stronger than the outer cortex. Yet, the fibers within the ring do not provide the strength admired in the stele. This is because the ring fibers are much shorter than the stele fibers and because the ring is surrounded on either side by unsclerified parenchyma cells; providing little tensile strength.

Although the ring is discarded along with the rest of the cortex, it increases the utility of $H$. flexuosa roots in an unexpected way. Due to the particular anatomy of $H$. flexuosa, the epidermis and cortex peel off easily, breaking just inside the circumstelar ring at the endodermis. The ring provides the structural boundary 
necesary for a clean, sharp break. Evodianthus funifer has stronger absorbing roots than $H$. flexuosa, but its cortex does not peel easily. The cortex of $E$. fumifer has a more even distribution of sclerenchyma and removal requires vigorous scraping. E. funifer is therefore used by indigenous groups only in areas where $H$. flexuosa is not available.

Wilder (1986b) mentions that a broad cortical sclerenchymatous ring likely evolved as: 1) protection against herbivores and pathogens; and 2) an adaptation to the high pressure differentials between the stele and cortex in epiphytic roots (due to occasional drying). Wilder showed that most epiphytic Cyclanthaceae species possess the sclerenchymatous ring while most terrestial members do not.

Peripheral and nonperipheral stele. At maturity, the stele is dominated by densely packed, long, thick-walled fibers. The length of the fibers (mean $=1.5$ $\mathrm{mm}, \max =4.5 \mathrm{~mm}$ ) and their occurence in adjoining aggregates with little nonfiber tissue provides longitudinal strength. Further strength is provided by the even distribution of vascular fascicles throughout the stele (a solid symmetrical arrangement without a pith). Flexibility is provided by the evenly distributed vascular fascicles and the network of parenchyma in-between fiber aggregates. In accordance with this assessment, Dransfield and Manokaran (1994) stated that the best quality rattan stems for the rattan furniture industry have an abundance of sclerenchyma, an even distribution of vascular bundles, and are evenly lignified. 
Another characteristic of $H$. flexuosa roots is the ease of splitting entire roots longitudinally into strips. The roots generally split longitudinally along the interfascicular network and occasionally through xylem fascicles because these structures provide the least resistance.

Strongly sclerified root tissues in hemi-epiphytic monocots may have developed due to: 1) a lack of secondary vascular tissues (roots remain narrow and cannot replace damaged conducting cells); 2) the need for extra protection due to an exposed habit; and/or 3) the need for individual roots to function for a long time as organs on perennial plants (Wilder, 1986b).

Because fibers do not function well in conduction, a likely function of the interfascicular intrusive network is the lateral and longitudinal transport of substances within the interfascicular tissues. Wilder (1986b) considers the network homologous to a true pith, providing an efficient ratio of nonfibrous and fibrous tissues in cyclanthaceous species with wide steles. A likely function of the xylem sheath is the exchange of liquid between interfascicular tissue and xylem elements. 


\subsection{SUMMARY AND CONCLUSIONS}

In this chapter I present results on $H$. flexuosa distribution, habitat, and growth in unharvested forest areas with potential for commercial harvest. I found a substantial abundance of $H$. flexuosa within the three primary study habitats and at both the northern and southern research areas. The documented preference of nibbi for moderately drained habitats provides predictive ecological data in surveying for robust nibbi populations.

I show that $H$. flexuosa mature clusters occur most often between the upper trunk and lower branches of host trees, in medium light levels. Definition of preferred host position is useful in predicting the mean height of mature clusters (and therefore roots) in different forest types. In addition, knowledge of $H$. flexuosa light and humidity requirements will be useful if cultivation is ever attempted. Although I did not quantify a preference for host species or host dbh, I observed distinct host exclusion of $H$. flexuosa in very few cases (Chlorocardium rodiei, emergents, palms).

My data shows that nibbi stems are slow growing, with the capacity for more rapid growth intermittently. Absorbing root growth is more rapid than stem growth, although a larger root sample size is needed. Due to slow or non-existent growth rates in many stems, the outlook for cultivation as a replacement for harvested plants is not promising The ability for roots to regenerate is more important to study in terms of sustainability. 
The significant results of the root growth data in terms of the potential for ecological sustainability are that, within 6 months: 1 ) more than $50 \%$ of immature roots matured significantly, but $38 \%$ did not; 2 ) some unestablished, immature roots became harvestable; and 3) some newly emergent roots grew very rapidly ( $3.2 \mathrm{~m}$ maximum). Studies with larger sample sizes and longer time-frames are needed to more thoroughly document $H$. flexuosa growth and maturation.

In addition, my anatomical study shows that the unusual strength and flexibility of $H$.

flexuosa absorbing roots is due to an even distribution of vascular tissues and the presence of densely packed, aggregated fibers within the stele. The anatomical data can be used for comparison with other potential fiber products and to understand the basis of root macrocharacteristics. 


\section{CHAPTER III. IMPACT OF AERIAL ROOT HARVEST ON NIBBI}

\subsection{INTRODUCTION}

Biological characteristics of Heteropsis flexuosa such as clonal growth and vegetative placticity make it adaptive to natural or human disturbance. In addition, because only the root is used, harvest does not require plant mortality as with many other plants, such as rattans. Yet, harvesting levels based solely on demand have severely reduced Heteropsis populations in other parts of South America (Salick 1992). There is clearly a harvest threshold level, but data is lacking for Heteropsis species. My study measures, directly and indirectly, the population and individual response of nibbi to harvest. From the results, simple management guidelines can be drawn up to minimize negative effects and encourage sustainable harvest.

In this chapter, I show that the number of harvestable roots per host tree is much less than the total number per host tree, indicating a low one-time harvest intensity. In addition, I compare population structure and root abundance between a post-harvested and unharvested site as a measure of longer term harvest impact. Finally, in root removal experiments, I show the short term response of individual $H$. flexuosa stems and roots to harvest, including the growth rate of re-generating roots. 


\subsection{MATERIALS AND METHODS}

\section{Plots and habitats}

To document harvest intensity and to compare post-harvested and unharvested plots, my field assistants and I worked within 0.1 ha $(20 \mathrm{~m} \times 50 \mathrm{~m})$ study plots previously established at the Manawarin and Iwokrama research areas (Fig. 1.4, Table 2.1). We also established 10 new plots at Manawarin. Plot methodology and habitat definitions are explained in Ch. 2.2 .

\section{A) HARVEST INTENSITY}

I use the term "harvest intensity" to indicate the potential percent removal of total roots per tree from a one-time-harvest. Details of traditional nibbi harvest methods in Guyana are explained in Chapter 1.3. In short, harvesters grasp and pull on a root, using all of their body weight, until the root breaks. Trunk roots (Fig 1.3) wrap around host trees and are generally considered unusable while drop roots are the primary product sought by nibbi harvesters. Because only product-quality drop roots are extracted for furniture production, the ratio of trunk to product-quality drop roots is important in addressing ecological sustainability of harvest.

To document potential one-time harvest intensity our team counted the number of harvestable roots and total roots present on individual host trees within 490.1 ha $(20 \mathrm{~m} \mathrm{x}$ 
$50 \mathrm{~m})$ study plots. The plots were those remaining in mixed forest/well-drained (H2), mixed forest/poorly-drained (H3), and Mora forest/riparian (H4) habitats after eliminating the Greenheart forest on steep slopes (H1) and Swamp/palm marsh (H5) habitats from analysis (Ch. 2.3). I chose 12 plots at Manawarin within $\mathrm{H} 2$ habitat and 27 plots at Iwokrama within various habitats, observing a total of 1,026 host trees. I made classed counts of trunk (Table 2.2) roots and individual counts of potential product roots. Classed counts were made due to time limitations and the difficulty of counting trunk roots massed together on trees, and are probably an underestimate. Product roots were chosen with the help of experienced nibbi harvesters in the field. The product roots were distinct because they were usually of the "drop root" variety that descend without touching the host trunk.

\section{B) HARVEST IMPACT}

\section{UNHARVESTED AND POST-HARVESTED PLOTS}

Population Structure. To study the impact of commercial harvesting, we established ten new 0.1 ha plots within post-harvested $\mathrm{H} 2$ habitat (3-5 years previously) at Burahara Creek, Manawarin. We compared the new plots with data from nearby, previously established 0.1 ha plots. In the Manawarin area there is a system of resource extraction tenureship, so nibbi extractors know where and when commercial harvest has taken place. Although the history of forest use within the plots is unknown, I observed harvest indicators such as broken roots and fallen plants in the "post-harvested" area. 
None of these indicators were observed in the "non-harvest" area. To quantify the impact of harvest on recruitment and survival, I observed differences between the harvested and post-harvested areas in the number of colonized trees, juvenile size-classes, and absorbing roots. The definition of size-classes is given in Chapter 1.1 (Fig. 1.1).

Size-class distribution data is commonly used to indicate the reproductive health of populations by recording the number of individuals in different classes within a study area (Harper 1977, Peters 1994). It is questionable, though, if the traditional juvenile to adult size-class distribution used for trees can be applied to vegetatively-plastic Heteropsis populations. H. flexuosa genets in younger size-classes are clearly discernible on host trunks, but adult genets can rarely be distinguished (Ch 1.1). Therefore, I consider the colonization density of mature clusters and the number of younger stems as separate data I determined mature stem colonization density by recording the presence on any host tree ( $\geq 10 \mathrm{~cm} \mathrm{dbh)} \mathrm{of} \mathrm{one} \mathrm{or} \mathrm{more} \mathrm{mature} \mathrm{H.} \mathrm{flexuosa} \mathrm{clusters} \mathrm{(Ch.} \mathrm{2.2).} \mathrm{To} \mathrm{quantify} \mathrm{the}$ younger size classes (genet recruitment), the number of seedling and juvenile individuals below $2 \mathrm{~m}$ on all trees $(\geq 10 \mathrm{~cm} \mathrm{dbh}$ ) were counted within the same 0.1 ha plots used for colonization density.

Root Abundance. As a further comparative measure of harvest impact, total roots, product roots, and broken roots were counted at the post-harvested and unharvested sites I used the same methods of root selection and counting as described above for harvest 
intensity. Product and broken roots were counted individually. It is likely that many of the broken roots originally present had decomposed or were hidden from view.

\section{DIRECT HARVEST EXPERIMENTS: IMPACT ON INDIVIDUAL STEMS AND ROOTS} Survivorship and Growth Rates. Direct harvest studies measured the impact on $H$. flexuosa occupying individual host trees rather than plots. Fieldwork occured within undelineated experimental sites at Manawarin and Iwokrama, and within some of the 0.1 ha plots. I climbed most of the host trees, used clippers or clipper poles to cut roots at a 10 $15 \mathrm{~m}$ height, and marked the remaining attached portions. One hundred fifty mature roots on a total of 61 host trees were cut, an average of 2.5 roots per host tree. This approximates the average number of roots per tree removed by harvesters. Roots were cut in February 1996 and I returned six months later, in August 1996, to observe the response to harvest. My original plan was to break and mark roots to simulate the effect of nibbi harvesters, but this proved to be impractical. Roots snapped by pulling from the ground tend to break in inaccessible locations on the root or on the host tree and then cannot be marked. Another experimental strategy was to climb trees and break roots by hand. This was not possible because roots can only be broken at a node (Ch. 1.1) or at the plant stem and these points are often inaccessible. In addition, only pulling from the ground would truly simulate the present harvest techniques. Because plots are permanently marked longer-term harvest responses can be measured in the future. 
Harvest impact variables included:

1) mature cluster: healthy, damaged, or dead;

2) individual root: re-growing, alive without re-growth, or dead;

3) new roots issued from a mature cluster: presence/absence and count; and 4) re-growing roots: growth rate. 


\subsection{RESULTS AND DISCUSSION}

\section{A) HARVEST INTENSITY}

The riparian (H4) habitat had a significantly larger mean number of trunk roots and of harvestable roots per host tree than the mixed forest/well-drained $(\mathrm{H} 2)$ and mixed forest/poorly-drained $(\mathrm{H} 3)$ habitats (Table 3.1; ANOVA, $\mathrm{P}<0.001$ ). $\mathrm{H} 2$ habitats at the Iwokrama and Manawarin sites were not different in mean number of trunk roots or product roots per tree ( $t$ test, $P>0.05$ ). In terms of the percent of harvest roots to total roots, the $\mathrm{H} 2$ habitat was not significantly different from the $\mathrm{H} 1$ and $\mathrm{H} 3$ habitats, while the $\mathrm{H} 1$ and $\mathrm{H} 3$ habitats were different from one another (ANOVA, $\mathrm{P}<0.05$ ). Manwarin and Iwokrama were no different statistically in percent of harvest roots to total roots ( $t, P>$ 0.05). In comparing the distribution of roots for all plots, I found there to be a significantly greater number (often more than ten times) of trunk roots than product roots per host tree $\left(\chi^{2}, \mathrm{P}<0.001\right)$. Seventy-three percent of the host trees had only trunk roots and product roots outnumbered trunk roots on only $3 \%$ of the host trees (Table 3.2 ). The largest number of trunk roots on a single host tree was 62 and the largest number of dropping roots on a host tree was 25 .

H4 habitat had much more robusi nibbi populations than the other habitats in terms of absorbing roots, with approximately 9 trunk roots and 1.5 product roots per host tree. But, $\mathrm{H} 4$ habitat also had the highest ratio of harvestable root to the total present. Losing a higher percentage of roots has the potential for a greater harvest impact, but this would be minimized by the sheer volume of roots on $\mathrm{H} 4$ habitat host trees. 
The Manawarin and Iwokrama sites had similar root abundances and percentages of potential removal per host tree in $\mathrm{H} 2$ habitat. Thus, my initial results show no difference in potential root harvest or impact between similar habitats at my study sites in northwest and central Guyana. For more robust comparison, future studies should collect data in non-H2 habitats of the North-West District.

\section{B) HARVEST IMPACT}

\section{COMPARISON OF UNHARVESTED AND POST-HARVESTED PLOTS}

Stems: Colonization density and recruitment. Harvested and unharvested plots at Manawarin did not differ in colonization density or in size-class distribution of seedling and juvenile stages (Table 3.3 Mann-Whitney U, NS). There were 57.3 \pm 7.24 SE seedlings and $26.7 \pm 3.67 \mathrm{SE}$ juveniles per 0.1 ha in the unharvested site and $45.2 \pm 4.05$ SE seedlings and $36.7 \pm 4.90 \mathrm{SE}$ juveniles in the post-harvested site. There were $17.2 \pm$ 2.24 trees colonized by mature clusters in the unharvested site per 0.1 ha and $15.8 \pm 1.29$ colonized trees in the post-harvested site.

Roots: Total Root and Product Root Abundance. I found no significant difference in total absorbing root abundance between the unharvested and post-harvested sites, with $117.5 \pm 12.1 \mathrm{SE}$ roots per 0.1 ha and $99.7 \pm 13.1 \mathrm{SE}$ roots per 0.1 ha, respectively. In terms of product quality roots though, there were significantly more per 0.1 ha at the 
Table 3.1 No. trunk and drop roots per host tree arranged by habitat and site

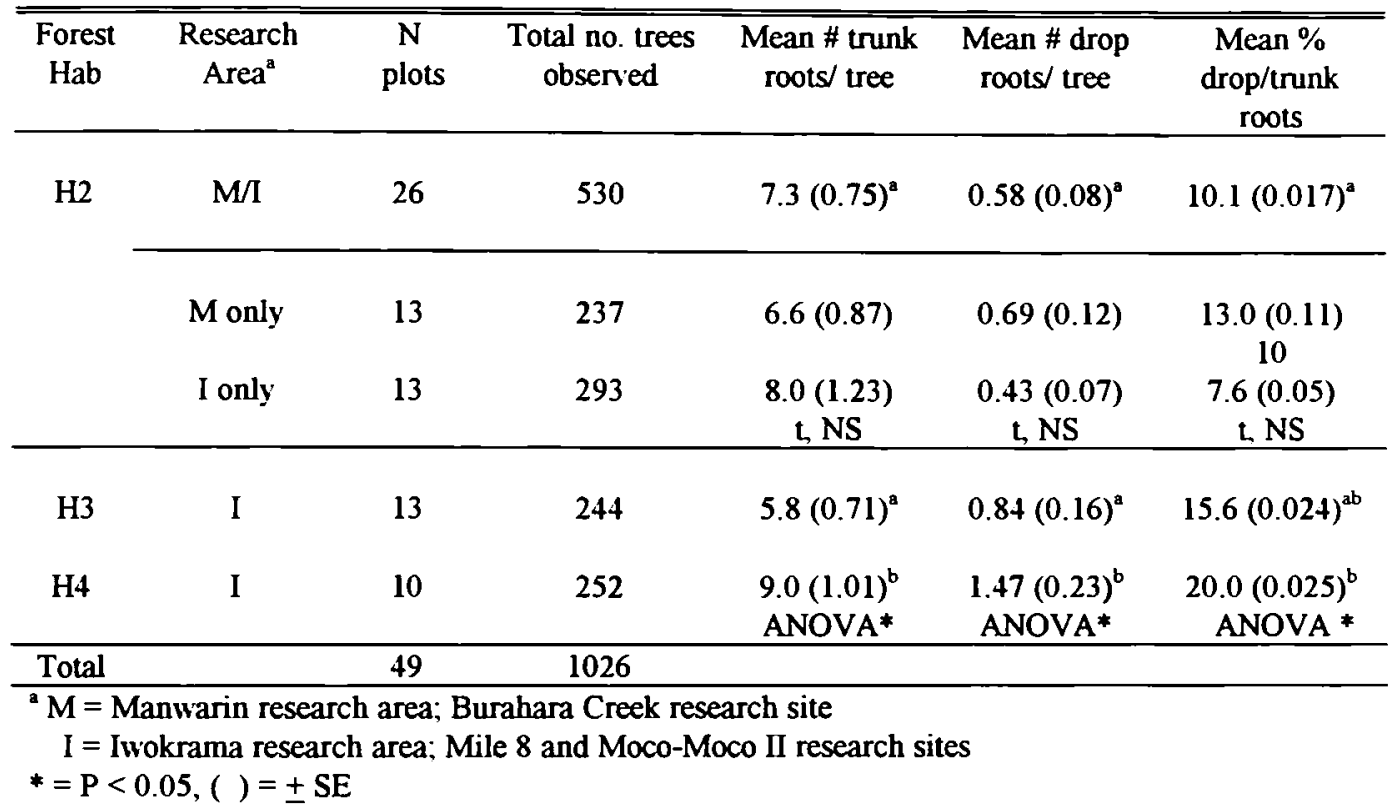

Table 3.2 Frequency distribution of $H$. flexuosa trunk and drop roots on host trees: grouped $\mathrm{H} 2, \mathrm{H} 3$ and $\mathrm{H} 4$ habitats

\begin{tabular}{lcccc}
\hline \hline Root size class & $\begin{array}{c}\text { No. host tree } \\
\text { (trunk roots) }\end{array}$ & $\%$ & $\begin{array}{c}\text { No. host tree } \\
\text { (product roots) }\end{array}$ & $\%$ \\
\hline 0 roots & 0 & 0 & 757 & 74 \\
$2.5(1-5$ roots) & 611 & 60 & 223 & 21 \\
$7.5(6-10$ roots) & 176 & 17 & 29 & 3 \\
$12.5(11-15$ roots) & 105 & 10 & 14 & 1 \\
$17.5(16-20$ roots) & 111 & 11 & 1 & 0 \\
$22.5(>20$ roots) & 23 & 2 & 2 & 0 \\
\hline Total & 1026 & & 1026 & \\
\hline
\end{tabular}


Table 3.3 Size-class distribution and root abundance of $H$. flexuosa in harvested and unharvested plots at the Manawarin study site

\begin{tabular}{|c|c|c|c|c|c|c|}
\hline \multirow{2}{*}{$\begin{array}{l}\text { Forest } \\
\text { Habitat }\end{array}$} & \multirow{2}{*}{$\begin{array}{l}\text { No. seedling } \\
/ 0.1 \text { ha }\end{array}$} & \multirow{2}{*}{$\begin{array}{c}\text { No. } \\
\text { juvenile } \\
\text { / } 0.1 \text { ha }\end{array}$} & \multirow{2}{*}{$\begin{array}{c}\text { No. } \\
\text { colonized } \\
\text { trees } 0.1 \text { ha }\end{array}$} & \multicolumn{3}{|c|}{ No. roots/ 0.1 ha } \\
\hline & & & & total & product & broken \\
\hline Manawarin $\mathrm{H} 2$ & & & & & & \\
\hline $\begin{array}{l}\text { Unharvested } \\
\mathrm{n}=12\end{array}$ & $\begin{array}{c}57.3 \\
(7.24)\end{array}$ & $\begin{array}{c}26.7 \\
(3.67)\end{array}$ & $\begin{array}{c}17.2 \\
(2.24)\end{array}$ & $\begin{array}{l}117.4 \\
(12.1)\end{array}$ & $\begin{array}{c}6.2 \\
(1.0)\end{array}$ & 0 \\
\hline $\begin{array}{l}\text { Manawarin H2 } \\
\text { Harvested } \\
\text { (3-5 yrs prev) }\end{array}$ & $\begin{array}{c}45.2 \\
(4.05)\end{array}$ & $\begin{array}{c}36.7 \\
(4.90)\end{array}$ & $\begin{array}{c}15.8 \\
(1.29)\end{array}$ & $\begin{array}{c}99.7 \\
(13.1)\end{array}$ & $\begin{array}{c}2.7 \\
(0.9)\end{array}$ & $\begin{array}{c}2.2 \\
(1.1)\end{array}$ \\
\hline$n=10$ & $\mathrm{U}, \mathrm{NS}$ & $\mathrm{U}, \mathrm{NS}$ & $\mathrm{U}, \mathrm{NS}$ & $\mathrm{U}, \mathrm{NS}$ & $\mathrm{U}^{*}$ & $\mathrm{U,*}$ \\
\hline
\end{tabular}

unharvested site $(6.2 \pm 1.0 \mathrm{SE})$ than at the post-harvested site $(2.7 \pm 0.9 \mathrm{SE})$. The number of broken roots was significantly different also, with $2.2 \pm 1.1 \mathrm{SE}$ per 0.1 ha at the postharvested site and 0 observed at the harvested site. (Table 3.3, Mann-Whitney $U, P<.05$ ).

One difficulty in interpreting this data is that the pre-harvest size class distribution and root abundance in the post-harvested plot is not known. If densities were originally much higher within the post-harvested site compared to the unharvested site, my results may underestimate the impact of harvest. It appears that the impact of harvest on mature cluster survival and juvenile recruitment is negligible in the post-harvested area. Although it is not statistically significant, the number of seedlings in the harvested site is lower than 
that of the unharvested site. This could indicate that new seedling recruitment has fallen slightly since harvest.

That there is some negative impact of harvest is clearly seen in the significantly lower number of product roots and higher number of broken roots visible at the post-harvested site. But, despite the negative effects, harvesting has not decimated mature stems, total number of roots, or the recruitment capacity of the population at this study site.

During fieldwork I observed five mature nibbi plants that had been pulled to the ground as a result of harvesting (in the past) and several others whose host tree had fallen to the ground. All of the plants had a least a few absorbing roots remaining in the ground. Despite severe disturbance none of the plants died during the six months of my study. Each had sent leaders with long internodes and reduced leaves across the ground, presumably in search of a new host tree. This shows the resilience of $H$. flexuosa plants even when subjected to a level of disturbance that rarely occurs during harvesting. 


\section{C) DIRECT HARVEST: IMPACT ON INDIVIDUAL STEMS AND ROOTS}

\section{STEMS: SURVIVORSHIP and 2. ROOTS: SURVIVORSHIP, GROWTH RATES}

Out of 150 individually cut roots that I observed, 33\% exhibited re-growth from the apex, $44 \%$ exhibited no signs of either re-growth or mortality, $17 \%$ of the roots died, and $5 \%$ were lost due to a single tree fall (Table 3.4 ). Of the 50 roots that regrew, I documented a mean growth rate of $1.17 \mathrm{~m}$ in 6 months or $20 \mathrm{~cm}$ a month. The maximum root re-growth in six months was $2.54 \mathrm{~m}$. Single cut roots often issue two to four new small diameter roots. 1.7 mean roots were issued from every re-generating root. Of the 61 host tree sites where roots were cut, $56 \%$ of the mature clusters exhibited new growth.

I found no statistical correlation between the number of roots cut and the response of 28 individual plants (Table 3.5). Due to the growth habit of nibbi, it is likely that I removed some roots not connected to study plants. I observed a general pattern in plants with minimal and maximal percentages of roots cut. Individuals with $100 \%$ of their roots cut invariably died, those with more than $80 \%$ cut invariably showed signs of stress (branch dieback, yellowing of leaves), those with 40-80\% cut were unpredictable, and those with less than $40 \%$ showed signs of stress in only one case. On hundreds of host trees, the removal of one to three roots in removal experiments had no apparent effect on $H$. flexuosa stems. 
Table 3.4 Response of $H$. flexuosa stems and roots to root harvest after 6 months (February 1996 - August 1996)

\begin{tabular}{lccc}
\hline Root response variables & $\begin{array}{c}\mathrm{N} \\
\text { roots }\end{array}$ & $\begin{array}{c}\text { Mean growth rate } \\
6 \mathrm{mos}\end{array}$ \\
\hline $\begin{array}{l}\text { Hariested root regrows } \\
\text { New root from stem }\end{array}$ & 41 & 28 & $\begin{array}{c}1.17 \mathrm{~m} \pm 0.12 \mathrm{SE} \\
(20 \mathrm{~cm} / \mathrm{mo})\end{array}$ \\
$\begin{array}{l}\text { No growth/alive } \\
\text { No growth/dead }\end{array}$ & 14 & 9 & 41 \\
Lost/ tree fall & 60 & 17 & \\
\hline Total & 7 & 5 & \\
\hline $\begin{array}{l}\text { 'Experiments took place at Burahara Creek, Manawarin Village and Iwokrama International } \\
\text { Rainforest Reserve. }\end{array}$ & 148 &
\end{tabular}

Table 3.5 Correlation of percent roots cut with $H$. flexuosa stem and root response after 6 months (February 1996 - August 1996)

\begin{tabular}{lll}
\hline \hline $\begin{array}{l}\text { Variables correlated with \% roots cut from } \\
\text { individual plants (range } 25 \%-100 \% \text { ) }\end{array}$ & $\begin{array}{l}\text { Correlations: } \\
\text { Spearman Rank }\end{array}$ & Rho \\
$\mathrm{N}=28$ & & \\
\hline regrowth of roots (yes or no) & $\mathrm{p}=.35, \mathrm{NS}$ & $\mathbf{0 . 1 8}$ \\
\% root regrowth & $\mathrm{p}=.21, \mathrm{NS}$ & -0.22 \\
no. new roots & $\mathrm{p}=.50, \mathrm{NS}$ & -0.13 \\
no. dead roots & $\mathrm{p}=.85, \mathrm{NS}$ & -0.03 \\
no. damaged branches/mortality & $\mathrm{p}=.91, \mathrm{NS}$ & -0.022 \\
\hline
\end{tabular}


My results indicate that it is possible for roots to regenerate after cutting, a capacity that had not been documented previously. I also show that cut nibbi roots can grow relatively rapidly, although longer term data are needed. At the mean rate of $20 \mathrm{~cm}$ per month, a root broken at a ten meter height (the average length of harvested root portions) could reach the ground in four years. The naturally growing roots $(n=11)$ that $I$ measured (described in Chapter 2) grew more rapidly, a mean $26 \mathrm{~cm} / \mathrm{mo}$. I expected a slower initial growth rate for cut roots because extra energy is required to produce replacement roots

Of the roots that exhibited no new growth and yet did not die, more time is required before assessing their significance. If no other roots regenerate besides the $33 \% \mathrm{I}$ observed, then the harvestable root resource will be depleted easily by harvesters. I observed some mature clusters (14\%) with new roots but do not know if this is a direct harvest response. It was often difficult to tell if descending roots originated from the same stem whose roots were cut. As mentioned above, more than one new root is often issued from a single mature cut root. If each new root is considered an equal replacement (ecologically and market-wise) to a normal root, the percent of regeneration increases to $57 \%$. But, double roots are often smaller in diameter than the mother root. Therefore, the value of each new root is ecologically and economically reduced to a varying degree, depending on diameter and quality. 


\subsection{CONCLUSION AND SUMMARY}

In this chapter I discuss the impact of harvest in terms of the potential percent of root removal, the difference in stem and root abundance between a site harvested three to five years previously and an unharvested site, and the response of stems and roots over six months to direct root removal. My results show that the potential is good for ecologically (population) sustainable harvest but is questionable for sustained-yield harvest of roots.

\section{ECOLOGICAL SUSTAINABLILITY}

The high percentage of trunk root in comparison to product root per tree at all sites is a promising statistic for ecological sustainability, assuming that trunk roots remain unused in Guyana. With $73 \%$ of the host trees lacking any product roots, and product roots representing a very small percentage on $24 \%$ of the remaining trees, it will be difficult to decimate populations.

The Manawarin site had significantly fewer host trees per hectare (along with fewer total trees $\geq 10 \mathrm{~cm} \mathrm{dbh}$ ) than the Iwokrama site, yet the amount of trunk root and the percent of trunk root to harvestable root per tree is insignificantly different. Thus, harvest would apparently have no more of an impact on populations at Manawarin than Iwokrama , based on the percent root removal.

H. flexuosa stems within the riverine alluvial Mora forest habitat (H4) of Iwokrama had an exceptionally large abundance of trunk roots per tree and would likely be ecologically 
impacted less than plants within $\mathrm{H} 2$ and $\mathrm{H} 3$ habitats, despite the slightly higher percentage of harvestable roots to trunk roots in $\mathrm{H} 4$ habitat.

Post harvested plots at Manawarin were not statistically different from unharvested plots in size class distribution and in the number of trunk roots. This result provides further evidence that the harvest of nibbi roots, using current methods of harvest, does not severely impact nibbi populations.

The experiments on variable percentage root removal indicate that harvests of more than $80 \%$ are certainly damaging, and $100 \%$ will lead swiftly to mortality. It is difficult, though, to determine "whose roots belong to whom" on host trees. Fortunately, the percent of roots cut will normally be a small fraction of the total as discussed above. Romero (1993) recommended root removal be limited to $50 \%$ per plant, based on experiments with Heteropsis spruceana Schott. My recommendation is to prohibit any trunk root cutting and to limit drop root cutting to $50 \%$.

\section{SUSTAINED-YIELD HARVEST OF ROOTS (PRODUCT SUSTAINABILITY)}

Sustainability occurs when the harvest of a product from one site can occur repeatedly and indefinitely (Hall and Bawa 1993). For this to occur, production (growth) of the product must equal or exceed the amount of harvest (Peters 1994). I did not determine the amount of new root production at my research sites due to time limitations. For nibbi, the high ratio of trunk root to product root is encouraging for ecological sustainability, but 
reduces the potential for economic sustainability. With few roots available as product, it will be difficult to convince harvesters to leave good roots or younger roots behind for the future. This is especially true in areas without resource tenureship where the next person to come down the trail will likely harvest remaining roots.

In direct harvest experiments the majority of roots either died or showed no growth after 6 months and approximately one third re-generated. Thus, short term data indicates that production from cut nibbi roots is insufficient for sustained-yield harvest. In addition, at Manawarin I observed a significantly smaller number of harvestable roots at the postharvested site (3-4 years) than the unharvested site. This is indirect evidence that production is insufficient for sustained-yield over longer time periods. My data on immature root production show that growth rates and maturation time are not limiting factors for harvestable root replacement. The best hope for sustained-yield is in the production of new roots from mature clusters, but directly measured, longer term data is needed. 


\section{CHAPTER IV. ECONOMICS AND LOCAL IMPORTANCE OF NIBBI}

\subsection{INTRODUCTION}

Non-timber forest products have customarily been ignored or under-rated by governments and industry for their potential contribution to national, regional, and local incomes (Panayoutou and Ashton 1992b). Recently, an increasing number of researchers have attempted to quantify the economic value of NTFP harvest. Most have calculated higher returns in the long term from NTFP's than from logging, cattle ranching or agriculture (Balick and Mendelsohn 1991, Godoy et. al. 1993, Grimes et. al. 1994, Peters et. al. 1989). Economic valuation studies show potential value, but often do not convey the complexities of forest people's socio-economic conditions and market activities. For example, Padoch and de Jong (1989) found that only $2.5-3.5 \%$ of potential product was actually collected by villagers at one site in Peru.

In this chapter I consider multiple aspects of the nibbi furniture trade. First, the yield obtained by harvesters in plots was directly measured and used to calculate the monetary value of harvest per hectare. Next, I documented the perspectives and knowledge of local people about the importance of nibbi harvest. Lastly, the local market structure and pricing was determined through additional interviews. The harvest and marketing of nibbi furniture has the potential to provide benefits to many sectors of Guyanese society while maintaining the integrity of forest ecosystems, but the cottage-industry needs the support and interest of the government. 


\subsection{Materials ANd Methods}

\section{A) STANDING FOREST PRODUCT YIELD AND VALUE (AEREAL)}

\section{Plots and habitats}

To document the yield and value of $H$. flexuosa roots in different forest habitats, my field assistants and I worked within the 0.1 ha $(20 \mathrm{~m} \mathrm{x} 50 \mathrm{~m})$ study plots previously established at the Manawarin and Iwokrama research areas. I explain the plot methodology and habitat definitions in Ch. 2.2 (Table 2.1).

\section{YIELD OF ROOTS PER HECTARE.}

Our team harvested and measured the dimensions of absorbing roots in 320.1 ha plots (20 at Iwokrama and 12 at Manawarin). The field assistants were experienced nibbi harvesters who selected and pulled down the harvest-quality roots using their traditional techniques (Ch. 1.3). We used a $50 \mathrm{~m}$ tape measure and a metric caliper for length and width measurements. Because roots usually break during harvest, the lengths recorded are a measure of the "capturable" product using present harvesting techniques. Length measurements were correlated with the number of harvested roots to develop a regression equation for predicting available product. Although more root length could be obtained by climbing trees, this is a dangerous method and extractors presently can obtain sufficient root product without climbing. 
2. YIELD OF ROOT "INTERNODES" PER HA: NUMBER, LENGTH. AND USE CATEGORIES.

The root length per area alone is not a complete measure of available product. $H$. flexuosa absorbing roots exhibit irregularly-distributed "nodes" or bulges (Figure 1.3; Romero 1993) where lateral "replacement roots" (Wilder 1989) emerge to continue growth when the original root meristem is dead or damaged. These structures must be cut out by extractors, yielding "root internodes" of variable length (Fig 1.10). A high density of nodes can render roots useless regardless of total length.

At the Iwokrama and Manawarin basecamps, our team measured the distances between nodes of all harvested roots (365 total) from 0.1 ha plots. My field assistants and I then sorted the internodes into furniture, handicraft, and waste use categories based on the distance between nodes, overall straightness, insect damage, and cylinder integrity. Furniture quality internodes are 2 m or more in length and of the best quality. Secondclass furniture and handicraft internodes are those of decent quality but insufficient length (less than $2 \mathrm{~m}$ ). Waste internodes can be any length, but are of inferior quality (Figure 4.1). After sorting internodes, I determined the distribution of lengths in the different use categories. These data allow for a specific focus on furniture-quality root yield. Data for the mixed forest, poorly drained (H3) habitat must be used with some caution only three H3 plots were harvested due to time constraints. 


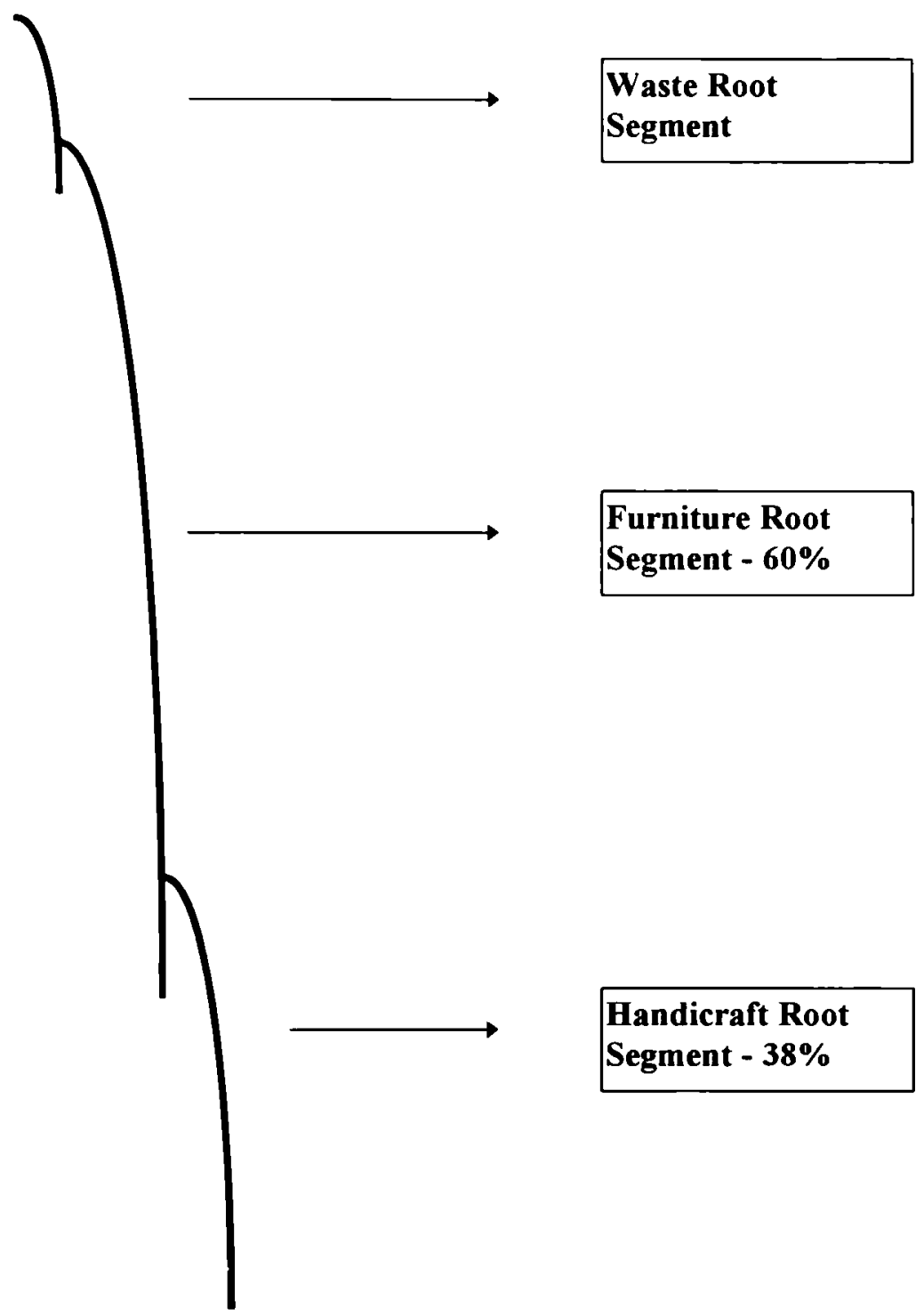

Figure 4.1 Nibbi root product use categories: furniture, handicraft, and waste 


\section{STANDING FOREST VALUE OF ROOTS PER HECTARE.}

Nibbi harvesters sell furniture-quality root internodes in bunches of 100 , with no set requirement for the mix of lengths. But, harvesters cannot sell their product if there are too many small pieces. To estimate the product value per forest hectare for harvesters, I defined the "acceptable mix" or sale unit and the area required to assemble it.

Based on five bundles measured at Liana Cane Interiors, a nibbi furniture factory in Guyana, I defined the nibbi root internode distribution in a standard bundle of 100 pieces (one sale unit) to consist of 5\% small lengths $2-3 \mathrm{~m}, 75 \% 3-4 \mathrm{~m}$ lengths, $12 \% 4-5 \mathrm{~m}$ lengths, $4 \% 5-6 \mathrm{~m}$ lengths and $4 \%$ lengths longer than $6 \mathrm{~m}$. I then determined the size distribution of internodes within my plots and, using the distribution of the sale unit as the target, estimate the area in my plots necessary to gather one sale unit. For example, in Table 4.2, the required number (5) of small lengths for the small-length portion of a roll in H2 habitat could be harvested within 0.07 ha. But, 75 internodes in the 3-4 m class are required and 2.07 ha must be covered in my plots to find that amount.

From the estimate of area required to collect one standard bundle of nibbi and the monetary value per bundle, I estimated the value of nibbi per hectare for harvesters in specific habitats and in all study plots. This study is a "best-case-scenario" because transects were made in areas where nibbi is already known to occur. I did not attempt to document the habitat range and root yield across large areas. The shorter internode lengths are sometimes sold as handicraft roots but they represent a minor part of the 
market and are not examined in this study. I found that most harvesters discard secondclass furniture and handicraft roots or use them locally because middlemen won't buy them, a situation that should be rectified.

\section{B) ECONOMIC IMPORTANCE AND VALUE OF HARVEST PER WORKING DAY}

For harvesters, the relative importance of harvesting forest products depends on the compensation received per working day rather than per hectare, although the two are related. Other decisive factors include the difficulty or danger involved in transport and extraction, the time spent away from home, and the degree of flexibility involved in the activity ( for ex: the ability to combine harvesting with other activities such as farming). To document the importance and earnings of nibbi harvesting, I interviewed six nibbi harvesters at Manawarin (Ch 1.3). I asked them about the number of trips per year, the usual length of nibbi harvesting trips, and the amount of nibbi obtained per trip. In addition, I asked them to compare the value of harvesting nibbi to other potential activities or occupations. To standardize monetary values for comparison with other studies or locations, I recorded the current cost of "essential goods" at the Charity market such as rice, sugar, and salt. I did not interview people on economic potential at the Iwokrama site because no furniture market has developed there. Details of traditional nibbi harvesting methodology are given in Chapter 1.3. 


\section{C) MARKET STRUCTURE}

I informally interviewed individuals and groups participating in the nibbi market to document the inter-relationships, product flow, and price changes at various points Groups involved included harvesters, middlemen, craftspeople, rural furniture producers, merchants, and furniture factory managers.

\subsection{RESUlTS AND DISCUSSION}

\section{A) RESULTS I: STANDING FOREST PRODUCT YIELD AND VALUE}

In this section I present data on root yield in forest plots in terms of total harvested root length, total furniture internode length, total handicraft root length, and the length and number of furniture-quality internodes (Table 4.1). Value is represented as a function of the area within my plots necessary to collect one "bundle" of nibbi, a unit with a known monetary value.

\section{LENGTH OF ROOTS, FURNITURE INTERNODES, AND HANDICRAFT INTERNODES.}

I found no statistical difference in mean total length of harvested root per 0.1 ha in riparian (H4) $(144.6 \mathrm{~m} \pm 26.2 \mathrm{SE})$, mixed forest/poorly-drained (H3) $(153.0 \mathrm{~m} \pm 46.2 \mathrm{SE})$ and mixed forest/well-drained $(\mathrm{H} 2)(126.9 \mathrm{~m} \pm 19.7 \mathrm{SE})$ habitats within Iwokrama sites (Kruskal-Wallis, NS). Grouping the three Iwokrama habitat types the mean total root length per 0.1 ha was $146.9 \mathrm{~m} \pm 16.6 \mathrm{SE}$. There was also no statistical difference between the three habitats at Iwokrama in the total additive length of furniture internodes (Kruskal- 
Wallis, NS). Grouping habitats, the mean total length of furniture-quality internodes per 0.1 ha was $86.0 \pm 10.5 \mathrm{SE}$. Furniture quality root length represented $60 \% \pm 0.03 \mathrm{SE}$ of the mean total root length. Handicraft internodes provided $38 \% \pm 0.05 \mathrm{SE}$ of the total root length within the three habitats at Iwokrama (Figure 4.1).

I found that the Iwokrama site, compared only for $\mathrm{H} 2$ habitat, was significantly greater in total root length and furniture internode length than the Manawarin site (Mann Whitney U, $P<0.05) .59 .3 \mathrm{~m} \pm 11.6 \mathrm{SE}$ total root length and $42.8 \mathrm{~m} \pm 9.5 \mathrm{SE}$ furniture internode length per 0.1 ha were obtained at Manwarin. $126.9 \mathrm{~m} \pm 19.7 \mathrm{SE}$ total root length and 74.1 $\mathrm{m} \pm$ 12.6 SE furniture internode length per 0.1 ha were obtained at Iwokrama. The percentage of furniture internode to total root length was similar at the two sites: $65 \%$ at Iwokrama and $68 \%$ at Manawarin. Roots consisted of $40 \% \pm 0.06 \mathrm{SE}$ handicraft length at the Iwokrama site and $23 \% \pm 0.05$ SE at the Manawarin site (Figure 4.1). Grouping all habitats together at both sites, furniture internodes made up $67 \% \pm 0.09 \mathrm{SE}$ of roots and handicraft internodes provided $32 \% \pm 0.03 \mathrm{SE}$.

\section{INDIVIDUAL ROOT DATA.}

The mean length of individual harvested roots from all habitats $(n=365)$ was $10.1 \mathrm{~m} \pm 5.1$

SE. Roots that broke at the plant stem, thus providing an accurate measure of natural total root length, were a mean $9.8 \mathrm{~m} \pm 5.1 \mathrm{SE}(\mathrm{n}=65)$. 
3. FURNITURE ROOT INTERNODES: MEAN LENGTH AND ABUNDANCE.

I found the $\mathrm{H} 2, \mathrm{H} 3$, and $\mathrm{H} 4$ habitats within Iwokrama not to differ in mean furniture internode number and length (Kruskal-Wallis, Tukey HSD post-hoc, $\mathbf{P}<0.05$ ). The furniture internodes in the three habitats (grouped) had a mean length of $3.8 \mathrm{~m} \pm 1.7$ SE and a count of $23.2 \pm 2.7$ per 0.1 ha (Table 4.1 ). I determined a positive correlation between root length and the number of furniture internodes (Pearson Product Moment Correlation; $r^{2}=0.93$ ) but no correlation with the mean length of furniture internodes $\left(\mathrm{r}^{2}=0.007\right)$.

I found a statistical difference in internode abundance/length between the Manawarin and Iwokrama research areas, in $\mathrm{H} 2$ forest habitat (Mann-Whitney $\mathrm{U}, \mathrm{p}<.05$ ). I recorded a count of $9.8 \pm 1.9 \mathrm{SE}$ internodes per 0.1 ha at Manawarin and 20.1 $\pm 3.5 \mathrm{SE}$ internodes at Iwokrama. The mean lengths were statistically non-significant for internode length, with $4.12 \mathrm{~m} \pm 0.26 \mathrm{SE}$ at Manawarin and $3.71 \mathrm{~m} \pm 0.06 \mathrm{SE}$ at Iwokrama. 
Table 4.1 Product yield from $H$. flexuosa absorbing roots per 0.1 ha arranged by habitat and site

\begin{tabular}{|c|c|c|c|c|c|c|c|c|}
\hline $\begin{array}{l}\text { Forest } \\
\text { Habitat }\end{array}$ & $\begin{array}{l}\text { Research } \\
\text { Area }^{\mathrm{a}}\end{array}$ & $\begin{array}{c}\mathrm{N} \\
\text { Plots }\end{array}$ & $\begin{array}{l}\text { total root } \\
\text { length (m) }\end{array}$ & $\begin{array}{c}\text { total } \\
\text { furniture } \\
\text { internode }^{\mathrm{b}} \\
\text { length (m) }\end{array}$ & $\begin{array}{c}\% \text { furniture root } \\
\text { /total }\end{array}$ & $\begin{array}{c}\text { no. } \\
\text { furniture } \\
\text { internodes }\end{array}$ & $\begin{array}{l}\text { mean length of } \\
\text { furniture } \\
\text { internodes (m) }\end{array}$ & $\begin{array}{l}\text { total handicraft } \\
\text { root length }(\mathrm{m})\end{array}$ \\
\hline $\mathrm{H} 2$ & M & 12 & $\begin{array}{c}59.34(11.57) \\
* \\
\end{array}$ & $\begin{array}{c}42.81(9.47) \\
* \\
\end{array}$ & $\begin{array}{c}68 \%(0.06) \\
\text { NS }\end{array}$ & $\begin{array}{c}9.8(1.9) \\
*\end{array}$ & $\begin{array}{c}4.12(0.26) \\
\text { NS }\end{array}$ & $\begin{array}{c}12.87(3.27) \\
*\end{array}$ \\
\hline $\mathrm{H} 2$ & I & 7 & $126.86(19.74)^{n}$ & $74.10(12.63)^{\mathrm{a}}$ & $65 \%(0.06)^{\mathrm{a}}$ & $20.1(3.5)^{\mathrm{n}}$ & $3.71(0.06)^{\mathrm{g}}$ & $52.15(14.19)^{\mathrm{a}}$ \\
\hline H3 & I & 3 & $153.31(46.18)^{\mathrm{a}}$ & $92.01(29.70)^{\mathrm{a}}$ & $66 \%(0.07)^{\mathrm{a}}$ & $18.8(6.4)^{\mathrm{a}}$ & $4.05(0.12)^{a}$ & $46.16(17.87)^{n}$ \\
\hline $\mathrm{H} 4$ & I & 10 & $144.58(26.20)^{\mathrm{a}}$ & $92.44(17.81)^{\mathrm{a}}$ & $55 \%(0.04)^{\mathrm{a}}$ & $25.4(4.6)^{a}$ & $3.88(0.33)^{\mathrm{a}}$ & $64.81(10.49)^{n}$ \\
\hline All Iwok & I & 20 & $\begin{array}{c}146.92(16.59) \\
\text { NS }\end{array}$ & $\begin{array}{c}85.96(10.52) \\
\text { NS }\end{array}$ & $\begin{array}{c}60 \%(.031) \\
\text { NS }\end{array}$ & $\begin{array}{c}23.2(2.7) \\
\text { NS }\end{array}$ & $\begin{array}{c}3.85(1.67) \\
\text { NS }\end{array}$ & $\begin{array}{c}59.66(7.35) \\
\text { NS }\end{array}$ \\
\hline
\end{tabular}

" $\mathrm{M}=$ Manwarin research area; Burahara Creek research site

I = Iwokrama research area; Mile 8 and Moco-Moco II research sites

b Root internodes are defined in this study as the root portion between root bulges ("nodes") due to lateral root cmergence.

$*=\mathrm{P}<0.05,()=\mathrm{SE}$ 
4. NUMBER OF ROOTS AND CORRELATION WITH LENGTH AND NUMBER OF INTERNODES The number of harvested roots per 0.1 ha between the Iwokrama habitats was insignificantly different at $14.3 \pm 6.7 \mathrm{SE}$ (Kruskal-Wallis, NS). The number of harvested roots between the northern and southern research sites in $\mathrm{H} 2$ habitat was different (Mann Whitney $\mathrm{U}, \mathrm{P}<0.05$ ) with 5.75 $\pm 3.4 \mathrm{SE}$ at Manwarin and $13.0 \pm 6.0 \mathrm{SE}$ at Iwokrama. For number of roots harvested I found a positive correlation with the total harvested root length (Pearson Product Momment Correlation, $r^{2}=0.93, P<0.05$ ) and with the number of furniture internodes $\left(\mathrm{r}^{2}=0.77, \mathrm{P}<0.05\right)$.

\section{YIELD TRANSLATED INTO NUMBER OF STANDARD BUNDLES PER HECTARE.}

I found that the minimum area required to collect one standard bundle is 2.07 ha in $\mathrm{H} 2$ habitat, 1.13 ha in $\mathrm{H} 3$ habitat, and 1.29 ha in $\mathrm{H} 4$ habitat (Table 4.2). In addition, to collect one standard bundle in $\mathrm{H} 2$ habitat at Manawarin would require 2.90 ha and at Iwokrama 1.81 ha. The limiting size class for all the habitats was the $3-4 \mathrm{~m}$ internode class.

\section{VALUE OF NIBBI ROOTS PER FOREST AREA BASED ON YIELD.}

Harvesters receive between US $\$ 5$ and $\$ 8$ per bundle of 100 internodes, depending on the overall quality. From the above estimate of the area required to collect one standard bundle of nibbi and the value per bundle, I determined the value of nibbi per hectare in specific habitats (Table 4.2). Conservatively basing the value of a bundle at $\$ 5$ (the minimum), the value per hectare in $\mathrm{H} 2$ habitat is $\$ 2.41$. The value in $\mathrm{H} 3$ habitat is $\$ 4.42$ 
per hectare and in $\mathrm{H} 4$ habitat it is $\$ 3.87$ per hectare. The Manawarin and Iwokrama sites, compared for $\mathrm{H} 2$ forest types have a value of $\$ 1.72$ and $\$ 2.76$ per hectare, respectively.

Table 4.2 Distribution of furniture root internodes and value per 1.0 ha arranged by habitat and site.

\begin{tabular}{|c|c|c|c|c|c|}
\hline $\begin{array}{l}\text { Sites/Habitats } \\
\text { internode } \\
\text { size-classes }\end{array}$ & $\begin{array}{l}\text { \# furniture root } \\
\text { internodes }\end{array}$ & $\begin{array}{l}\text { Total area } \\
\text { (ha) }\end{array}$ & $\begin{array}{c}\text { No. lengths } \\
\text { in standard } \\
\text { bundle }\end{array}$ & $\begin{array}{c}\text { Area } \\
\text { required } \\
\text { for bundle } \\
\text { (ha) }\end{array}$ & $\begin{array}{l}\text { Value at } \\
\text { \$5/bundle }\end{array}$ \\
\hline \multicolumn{6}{|l|}{ Manawarin/ H2 } \\
\hline $2-3 m$ & 49 & 1.2 & 5 & 0.12 & \\
\hline $3-4 m$ & 31 & 1.2 & 75 & 2.90 & \$ 1.72/ha \\
\hline $4-5 \mathrm{~m}$ & 11 & 1.2 & 12 & 1.30 & \\
\hline $5-6 m$ & 8 & 1.2 & 4 & 0.60 & \\
\hline$>6 \mathrm{~m}$ & 14 & 1.2 & 4 & 0.34 & \\
\hline \multicolumn{6}{|l|}{ Iwokrama/ H2 } \\
\hline $2-3 m$ & 82 & 0.7 & 5 & 0.04 & \\
\hline $3-4 m$ & 29 & 0.7 & 75 & 1.81 & $\$ 2.76 / \mathrm{ha}$ \\
\hline $4-5 m$ & 18 & 0.7 & 12 & 0.47 & \\
\hline $5-6 m$ & 17 & 0.7 & 4 & 0.16 & \\
\hline$>6 \mathrm{~m}$ & 7 & 0.7 & 4 & 0.40 & \\
\hline \multicolumn{6}{|l|}{ Iwokrama/H3 } \\
\hline $2-3 m$ & 34 & 0.3 & 5 & 0.04 & \\
\hline $3-4 m$ & 20 & 0.3 & 75 & 1.13 & $\$ 4.42 / \mathrm{ha}$ \\
\hline $4-5 m$ & 4 & 0.3 & 12 & 0.90 & \\
\hline $5-6 m$ & 2 & 0.3 & 4 & 0.60 & \\
\hline$>6 m$ & 10 & 0.3 & 4 & 0.10 & \\
\hline \multicolumn{6}{|l|}{ Iwokrama/H4 } \\
\hline $2-3 m$ & 127 & 1.0 & 5 & 0.04 & \\
\hline $3-4 m$ & 58 & 1.0 & 75 & 1.29 & \$ $3.87 / \mathrm{ha}$ \\
\hline $4-5 m$ & 26 & 1.0 & 12 & 0.46 & \\
\hline $5-6 m$ & 14 & 1.0 & 4 & 0.28 & \\
\hline$>6 \mathrm{~m}$ & 23 & 1.0 & 4 & 0.02 & \\
\hline \multicolumn{6}{|l|}{ Iwokrama/All } \\
\hline $2-3 m$ & 286 & 3.2 & 5 & 0.05 & \\
\hline $3-4 m$ & 143 & 3.2 & 75 & 1.60 & $\$ 3.12 / \mathrm{ha}$ \\
\hline $4-5 m$ & 65 & 3.2 & 12 & 0.60 & \\
\hline $5-6 m$ & 43 & 3.2 & 4 & 0.30 & \\
\hline$>6 \mathrm{~m}$ & 54 & 3.2 & 4 & 0.30 & \\
\hline
\end{tabular}

Limiting size-class is the one requiring the largest area to complete a standard bundle (in bold). 


\section{B) DISCUSSION I: STANDING FOREST PRODUCT YIELD AND VALUE}

In the above section, I have quantified the yield of nibbi root obtained by harvesters in forest habitats with the potential for commercial harvest. This information is important as an initial effort at assessing the quantity of product available, finding shortcuts for inventory, and making predictions of available product in different areas. For example, a forest surveyor could test the equation generated from the positive correlation I found between number of harvested roots and the length or number of furniture internodes.

\section{HABITATS AT IWOKRAMA.}

The discussion of yield and value at Iwokrama is hypothetical because the nibbi furniture industry is presently only active in the near-interior of Guyana. Indigenous groups near Iwokrama use nibbi for subsistence purposes only. My data indicates the potential of the area for small scale commercial harvesting, an activity the Iwokrama International Rainforest Reserve is considering. The prices and market activity I discuss are all based on the Pomeroon and Manwarin area.

The mean total length of absorbing root harvested per 0.1 ha for all habitats at Iwokrama was approximately $147 \mathrm{~m}$. After processing, $60 \%(82 \mathrm{~m})$ of the original length could be sold in bundles to furniture market buyers. Most of the remaining root length is useful in handicrafts or basketry, but middlemen on the rivers at Manawarin won't buy small 
internodes. Considering the distribution of internodes per hectare (method described above), the value of nibbi within all plots at Iwokrama is approximately US $\$ 3.13$ per hectare ( 1 bundle per $1.6 \mathrm{ha}$ ). This is likely an underestimate because the longest internodes can be cut up to assemble more bundles than a simple distribution indicates. I estimated that in the total of 3.1 ha within Iwokrama plots, approximately four bundles could be made if other lengths were cut up, providing US $\$ 20-\$ 32$. This may seem like a remarkably good bargain for rural Guyanese, but collecting such quantities requires substantial scouting because nibbi populations are patchily distributed.

The $\mathrm{H} 3$ and $\mathrm{H} 4$ habitats have higher root length values than the $\mathrm{H} 2$ habitat at Iwokrama, although without statistical significance. Additional plots are required to make a robust assessment of $\mathrm{H} 3$ habitat, but I observed that $\mathrm{H} 4$ habitat provided conditions where nibbi populations thrive. As described in chapter two, Heteropsis flexuosa grows more abundantly in moist, non-inundated sites. Examples of this in my study were the Ladysmith and Akromukro lines at Iwokrama, dominated by Mora forest (Mora excelsa Benth.) near the Essequibo River. The combination of high humidity and taller forest provides conditions for high colonization abundance and long root lengths.

\section{IWOKRAMA VS. MANAWARIN}

Iwokrama area $\mathrm{H} 2$ plots had significantly greater product root lengths than at Manawarin, in all categories. In accordance with product root abundance, the estimated value of nibbi per hectare at the Iwokrama $\mathrm{H} 2$ site $(\$ 2.76)$ is almost twice the value at the Manwarin 
site $(\$ 1.72)$. The mean number of internodes was much greater at Iwokrama than at Manwarin, but the mean length per internode was not significantly different. Forests with more roots and larger lengths will likely provide more product, but not necessarily in direct proportion. For example, I observed a high density of smaller class $(<2 \mathrm{~m})$ internodes at the Iwokrama site. Long roots with many internodes may be less valuable than short roots with few internodes. Smaller internodes limit the amount of useful product at Iwokrama, but the high abundance of roots makes up for losses. In addition, as long as present harvest methods are maintained, the amount of root product obtained will be limited by the point of breakage.

\section{C) RESULTS I AND DISCUSSION II: ECONOMIC IMPORTANCE AND VALUE OF HARVEST PER WORKING DAY}

As mentioned above, nibbi harvesters at Manawarin are mostly olders boys and men who go on harvesting trips of variable length and for variable purposes. Some go for just one day to a nearby site and return before nightfall with a small amount of nibbi.

Others travel for several weeks, either specifically to harvest nibbi or to combine harvesting with farming, hunting, and fishing. Typically, about half the days spent on the journey involve direct harvest of nibbi. Traditionally, if any animal hunting opportunity occurs, nibbi harvesting is postponed immediately. Harvesters usually travel in pairs or in small groups and sometimes an entire family participates together. Groups go out specifically for nibbi or kufa (Clusia spp) and do not usually combine the two activities. I was not able to determine a reliable yearly harvesting expedition frequency for individuals. 
The total distance covered ranges from five to forty miles, but harvesters stay within the greater Manawarin watershed. When water levels fall, two or three days of walking are required to reach harvest areas in the upper watershed.

One person can count on collecting 1 to 2 bundles per day (100 to 200 pieces), once he or she is at a harvesting site. On a particularly good day harvesters collect up to 5 bundles, but this amount requires a lot of hauling effort and time. Thus, at a conservative US $\$ 5$ per bundle, harvesters usually earn between US $\$ 5$ and US $\$ 10$ per day and occasionally up to $\$ 25$ per day while at the harvesting site. With half the days consumed in travel to the site, the earnings are reduced by half per day, thus harvesters earn from US $\$ 2.5$ to US $\$ 5$ per work day and up to $\$ 12.5$. The harvester can increase the value of the root product by peeling the cortex off or by transporting it to the market himself, but this requires further time and labor committment. Not included in this assessment are the prices that the harvesters pay for clothing, food, kerosene, flashlight batteries, and other material items that are now considered essential.

When villagers at Manawarin seek goods they either barter for high priced goods at the village or they paddle to the town of Charity. To provide comparative data on the buying power of nibbi earnings, I documented the prices of basic goods at Charity market in August 1996. In U.S. currency, the prices were $\$ 1.78$ /gallon for white rice, $\$ 0.25 / \mathrm{lb}$ for sugar, $\$ 1.42 /$ gallon for kerosene, $\$ 0.18 / \mathrm{b}$ for salt, and $\$ 0.28 / \mathrm{lb}$ for flour. 
The options for a cash income or bartering power for material goods are limited at Manawarin. Workers can earn similar wages to nibbi harvest by harvesting kufa (US $\$ 10$ for $5014^{\prime}$ pieces) or capturing birds for the wildlife trade, but these are strenuous and dangerous occupations (tree climbing and hauling). One kufa harvester died while I was visiting the Pomeroon River area in 1996 . Workers hired by a new small scale mill at Manawarin earned US $\$ 5$ per day, but had to live at the logging camp away from their families and considered the work dangerous. Independent logging is a minor activity because few families can afford a chain saw and hand sawing is too labor intensive. Mining requires traveling far from home, is dangerous, and provides no guaranteed wage.

Although I was told many times by harvesters that they deserve better prices, most prefer nibbi extraction to other options. For many families in the Manawarin community, nibbi harvesting is the single most important source of monetary income. The benefits of nibbi harvesting mentioned most often were 1) year-round product availability; 2) the ability to fit nibbi harvesting time in around other important activities such as farming and church events; 3) harvesting is not too strenous or dangerous; and 4) the ability to remain living with family in the village. 


\section{D) RESULTS AND DISCUSSION III: MARKET STRUCTURE}

For each market transition I include the socio-cultural group and role of the participants, the form(s) of the nibbi root product at that point, the changing value of one nibbi root bundle, and the profit made (Fig 4.2). I will also consider the overall pattern and possible change in the structure that could benefit indigenous harvesters at Manawarin.

\section{FOREST HARVEST}

As described above, forest harvesters are almost all indigenous men from Arawak or Carib communities. Other family members in the village participate in the processing of nibbi roots (de-corticating and/or scraping). The sale unit is a bundle of 100 internodes of varying lengths, averaging 3-4 m each. Root bundles are sold to a "coastlander" middleman at the village (one comes to Manwarin once a week) or they are transported to Charity market. The harvester is paid approximately US $\$ 5$ per unpeeled bundle by the middleman. In Charity, the harvester is paid approximately US $\$ 8.50$ per unpeeled bundle, but must make a strenuous four day roundtrip paddle to get there (and may spend all the extra money socializing with friends). Some harvesting families on the Pomeroon also make furniture or handicrafts and through this activity will receive more than triple the original village value for one nibbi bundle (US $\$ 17$ ). I found that the production of furniture is non-existent in the Manwarin area, although a few people make small craft items. 


\section{MIDDLEMEN}

Middlemen are largely young or middle-aged black men from more urban areas of Georgetown. They pilot speedboats or larger vessels to various locations up the Pomeroon River or to Manawarin and Moruca Rivers (Fig. 1.2). Most middlemen are involved in a variety of trade activities, including the buying and selling of kufa, timber, wildlife, nibbi, and foodstuffs. They often bring items for barter with indigenous communities at marked up prices. The middlemen bring root bundles from harvesting communities to furniture makers and craftspeople at Charity market and may even transport them all the way to Georgetown. A root bundle sells for approximately US $\$$ 8.50 in Charity and thus the middleman earns US $\$ 3.50$ per bundle from the $\$ 5$ originally paid. Furniture factories in Georgetown pay approximately US $\$ 10$ per bundle. Therefore the middleman could make $\$ 5$ or more per bundle by paying transport to the capital. The trade is well worth it when many bundles are brought at once.

\section{POMEROON HANDICRAFT AND FURNITURE PRODUCERS}

Furniture producers along the Pomeroon River buy nibbi bundles from harvesters and middlemen or make their own trips upriver to harvest. Completed furniture is brought to Charity and then transported to Georgetown for the local or Caribbean market. Most of the furniture made in the Pomeroon region is of insufficient quality to be sold overseas. There is a wide range in the skills of furniture producers and therefore in the prices. Furniture is usually sold as a "set": one sofa, two chairs, and a small table. A simple, low quality set requires approximately one bundle of nibbi (\$8.5) and 30 pieces of kufa (\$ 6) 
and sells for $\$ 28$ in Charity. Thus, the value of the nibbi bundle within the furniture is doubled to $\$ 16-\$ 18$. Pomeroon producers receive approximately $\$ 40$ for a simple set from merchants in Georgetown or $\$ 28$ for the nibbi bundle within the furniture, almost double again.

I interviewed several craftspeople selling handicraft in Charity. Levi Smith buys two nibbi bundles a week at $\$ 7.5$ apiece and makes small handicrafts for a profit of $\$ 43$. Ingrid Fredericks buys nibbi bundles for $\$ 8.5$ and makes $\$ 53$ profit from nibbi baskets sold for $\$ 2$ each.

\section{GEORGETOWN FURNITURE MERCHANTS AND FACTORIES}

The primary furniture production businesses in Georgetown include: Collin Craft, Creation Craft, Liana Cane Interiors, and L Mart. All of these companies buy raw materials from middlemen and some also buy furniture from the Pomeroon. Both inexpensive furniture for the local market and high-end export furniture are produced in Georgetown. Liana Cane Interiors produces solely high-end export furniture and is planning large-scale increases in production (Cody 1990, 1996). According to a manager, the nibbi bundle bought for $\$ 10$ by Liana Cane Interiors is worth $\$ 172$ as a component of exported furniture built to international standards. Of course, many extra expenses are incurred and risks are taken in producing high quality furniture. The finishing supplies alone increase expenses by $35 \%$. Transport of furniture is a major expense because it is bulky and 
shippers charge more for space than weight. L-Mart is considering exporting raw materials to an assembly factory in Miami to save on shipping expenses. 


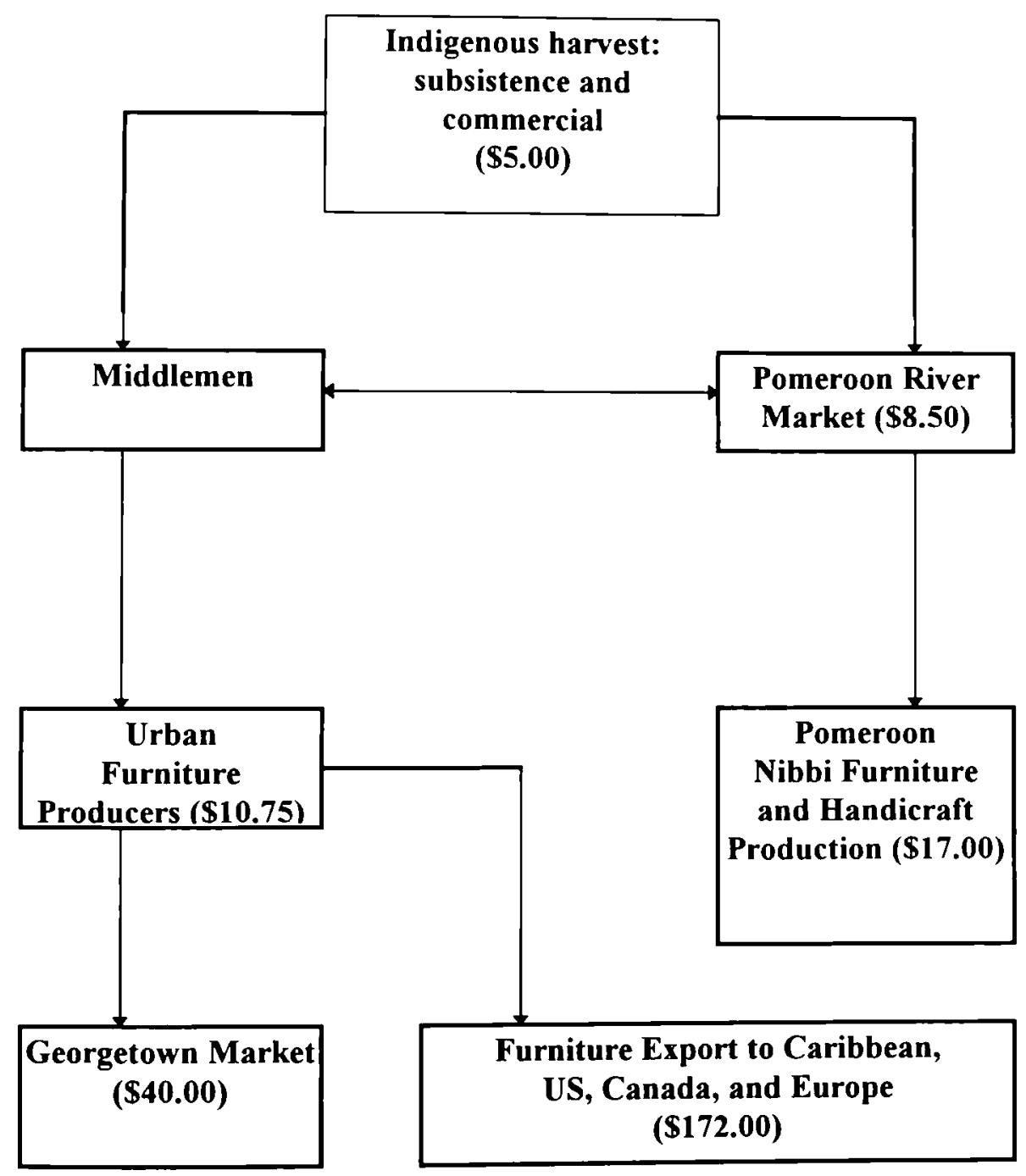

Figure 4.2 Nibbi furniture market structure and pricing.

( ) = US\$ value of 1 nibbi bundle [100 internodes] 


\section{MARKET STRUCTURE AND POSSIBLE CHANGES}

The nibbi furniture market provides benefits to many people in different segments of Guyanese society. Harvesters receive more money for nibbi harvesting than many other activities and are able to maintain their indigenous lifestyle. The middleman finds a decent profit just for transporting goods, makes a better wage than he would in town, and probably enjoys the freedom and adventure of working outdoors on the river. The Pomeroon River furniture producers enjoy making their own money without having to leave their families, as with indigenous people. In addition, many Pomeroon people are proud of their furniture-making skills. In Georgetown, the nibbi furniture merchants and factories are struggling to develop a larger, successful industry but many have been supported by the nibbi furniture business for years and enjoy the work.

The most difficult part of the work is certainly undertaken by the indigenous people who have to pull down and drag out heavy loads of nibbi through the forest. Most Amerindians I interviewed felt that they were not getting a good price for their work and were seeking ways to increase their profits. In particular, there was a lot of tension between Amerindians and middlemen, as might be expected. People at Manawarin felt that they were "held hostage" at times because the middleman knew that a two day paddle was required for them to sell their product independently. As a result, some middleman tell harvesters that their nibbi bundles have too many small lengths and wouldn't pay the normal price. This is encouraged by the lack of a standard for the assortment of lengths. 
The increase in value from raw product to the most sophisticated furniture can be seen in Figure 4.2. The value of one nibbi bundle increased more than 35 times in moving from an indigenous harvester to becoming a component of export-quality furniture. This increase is not necessarily unfair because many expenses are incurred in producing quality furniture and this is out of the scope of a possible indigenous occupation. Harvesters could get a larger share by forming an organization that sells nibbi directly to Georgetown furniture producers. In addition, communities such as Manawarin could be encouraged to begin producing more crafts from the largely wasted handicraft roots or even to produce simple furniture at a central location for several villages.

\subsection{CONCLUSION AND SUMMARY}

In this chapter I have documented the potential yield and economic value of nibbi at various sites. In addition, I have discussed the importance of the market to indigenous harvesters and the regional market structure and pricing.

Comparing north and south study sites, the Iwokrama habitats had similar, high yield and value, twice that of the Manawarin site. Because I only visited one area of Manawarin, though, it cannot be assumed that there are not other sites with abundant nibbi. Future studies should focus on surveying a larger area in the rainy season when boats can go far upriver. 
My data provides information about nibbi roots useful for inventories and the development of management plans. Government or indigenous surveyors can use the correlations with root length (or internodes) and root number to predict the amount of product available without harvesting roots. In addition, these data could be used to develop a standardized nibbi bundle size based on natural abundance, allowing less of the root to be discarded.

Many people in Guyana benefit from the harvest of nibbi. This study highlights the potential of the nibbi furniture market for linking the twin goals of development and conservation, and provides some guidance on how to quantify the value of nibbi roots. 


\section{Chapter V. Conclusions}

I have documented that the trade in nibbi roots and finished products is an important source of income for indigenous communities, creole farming families, entrepreneurs, and businesspeople in Guyana. Nibbi holds promise as a product that integrates the goals of forest conservation, national and regional development, and cultural integrity for indigenous people. Although the present level of harvest affects a very small percentage of Guyana's forests, management will become necessary if the nibbi market increases. Any successful management program should be based on an understanding of social, economic, and ecological conditions of both human populations and the natural resource to be harvested.

The primary objective of my research was to provide quantitiative data, qualitative data and recommendations for nibbi as a viable rain forest product. I have arranged my data into categories including: baseline data, inventory, management, cultivation, economic sustainability, ecological sustainability, economics, and social. Overall conclusions are listed by data category in the following pages. 
Ecological baseline data and inventory: How abundant are nibbi plants and where do they grow?

- Heteropsis flexuosa is a patchily-distributed, common plant in the lowland rainforests of Guyana.

- H. flexuosa plants preferred sites of moderate drainage (Mixed forest and Mora forest) and light intensity at upper trunk host tree positions.

- The Manawarin site had fewer total trees and fewer colonized trees per hectare than the Iwokrama site, although the percentage of trees colonized was the same.

- H. flexuosa may have difficulty establishing itself in Greenheart (Chlorocardium rodiei) forests due to the characteristic of exfoliating bark.

Ecological baseline data: What is the potential for cultivation?

- The outlook for cultivation is not promising

Nibbi stem growth rates are very slow and many stems exhibit dieback.

Nibbi has thin stem internodes that do not survive transplantation well.

Nibbi requires primary forest, humidity, and moderate light conditions.

Anatomical baseline product data: Why are nibbi roots so strong, light, and flexible?

- Strength is a result of densely packed fiber aggregates, evenly distributed within the stele. The large vessel and phloem elements provide lightness and flexibility. The network of parenchyma inbetween fiber aggregates, although somewhat sclerotized, provides flexibility also. 
Ecological and product sustainability: What is the impact of harvest?

- Ecological harvest sustainability is promising

Potential harvesting of nibbi using present harvest techniques is unlikely to decimate populations because the number of trunk roots per host tree are much greater than the number of harvest roots.

In post-harvested sites, the size class distribution of stems and the number of trunk roots was no different than in unharvested sites.

All plants with $100 \%$ of roots cut died, plant with less than $50 \%$ lived.

- Sustained-yield harvest is questionable

The number of product roots was significantly less in the post-harvested site. compared to the harvested site.

Only $28 \%$ of cut roots showed re-generative growth after 6 months.

Nibbi stem growth rates are usually slow and many stems exhibit dieback.

- Economic sustainability is not entirely hopeless

Cut roots can regenerate.

Re-generating roots and new roots grow and mature rapidly.

Cut roots sometimes issue more than one root.

There is no data yet on the production of new roots generated from mature clusters. 
Economic baseline data and inventory: what is the yield and value of nibbi root product?

- Nibbi roots have significant value per hectare in the study area.

- The number and value of root product can be predicted per hectare and per root.

- The mean number of furniture internodes (but not the mean length) correlates positively with the length of root harvested.

- The Iwokrama site, within one habitat, had twice the yield and value of the Manawarin site. Issues of sustainability aside, the Iwokrama area could become another center of nibbi furniture production.

Socio-economic baseline data: What is the importance of the nibbi furniture trade?

- For many families in the Manawarin community, nibbi harvesting is the single most important source of monetary income and allows them to maintain their indigenous lifestyle. Nibbi harvesters at Manawarin told me that host trees are more valuable to them as hosts than as timber for a local mill.

\section{Economic: Market Structure and Pricing}

- The nibbi furniture market provides benefits to many segments of Guyanese culture

- There is a 35 fold nibbi price increase between the harvester and its use in export quality furniture. 


\section{RECOMMENDATIONS}

For future research I recommend that:

- plots be established in variable habitats at Manawarin and other sites in the NorthWest District of Guyana.

- researchers use point transect or other rapid methods to document nibbi abundance patterns at the landscape level.

- non-host and host tree attributes be documented in ecological plots

- larger sample sizes and longer time-frames are made available to study $H$. flexuosa growth, maturation, and response to harvest.

- because so few cut roots re-generated in my plots, studies on the production of new roots are very important in the study of economic sustainability.

- experiments are made on different techniques of harvest.

The encouragement of minimally damaging harvest methods requires:

- ensuring that trunk roots and immature drop roots are never cut.

- cutting no more than $50 \%$ of the roots on any tree.

- the establishment of workshops in rural Guyana and the dissemination of educational pamphlets explaining the ecology of nibbi and its requirements for survival.

- leaving harvested areas alone for at least five to ten years to allow new root production.

- secure land tenure

In addition, it is possible that novel techniques could be experimented with, such as planting seeds or cutting and hanging trunk roots away from trees so they grow straight 
down. Through this method the number of harvest roots could be increased, although more care must be taken not to cut too many roots.

To improve their earnings and increase political power, harvesters in the Pomeroon/Moruca area should form an organization that sells nibbi directly to Georgetown furniture producers. In addition, men and women in communities such as Manawarin could be encouraged to begin producing crafts or simple furniture to claim some of the "value-added" mark-up.

Despite its economic, cultural and conservation values, the government of Guyana does not recognize the nibbi furniture industry as having much promise. Panayotou and Ashton (1992) stated some of the reasons why governments neglect non-timber forest products These include: 1) lack of adequate information concerning their economy and biology; 2) lack of established markets; 3 ) irregular supply and difficulty to maintain quality standards; 4) replacement by artificial substitutes; 5) lack of technology to process and store; and 6) low net return to major trading interests. Nibbi has a well established market, has not been replaced by artificial substitutes, and does not require special technology for processing and storage. In addition, irregular supply does not have to be a problem if harvesters receive real benefits in their role as suppliers. Low net return and a lack of information on biology and economics are major contributing factors in neglect of the nibbi market. 


\section{LITERATURE CITED}

Allegretti, M. H. 1990. Extractive reserves: An alternative for reconciling development and environmental consenation in Amazonia. Pages 252-264 in A. B. Anderson. ed.. Alternatives to deforestation: steps toward sustainable use of the Amazon rainforest. Columbia University Press. New York.

Anderson, A. B. 1990. Deforestation in Amazonia: Dynamics. causes, and alternatives. Pages 3-23 in A. B. Anderson, ed.. Alternatives to deforestation: steps toward sustainable use of the Amazon rainforest. Columbia University Press, New York.

Ave, W. 1988. Small-scale utilization of rattan by a Semai community in west Malaysia. Economic Botany 42:105-119.

Balick, J. B. and R. Mendelsohn. 1991. Assessing the economic value of traditional medicines from tropical rain forests. Consenvation Biology 6:128-130.

Beer, J. H. de and M. J. McDermott. 1989. The economic value of non-timber forest products in Southeast Asia. Netherlands Committee for IUCN, Amsterdam.

Bennett, B. 1992a. Plants and people of the Amazonian rainforests: the role of ethnobotany in sustainable development. Bioscience 42:599-607.

- 1992b. Uses of epiphytes, lianas, and parasites by the Shuar people of Amazonian Ecuador. Selbeyana 13: 99-114. (H. cf. oblongifolia).

Benzing, D. H. 1983. Epiphytism: a preliminary overview. Pages 31-43 in Vascular epiphytes. general biology and related biota. Cambridge University Press, Cambridge.

Brako, L. and J. L. Zarucchi. 1993. Araceae. Page 76 in Catalogue of the flowering plants and gymnosperms of Peru. Volume 45. Missouri Botanical Garden, St. Louis. (H. linearis, H. oblongifolia, $H$. peruviana, $H$. spruceana var. robusta).

Browder, J. O. 1992. Social and economic constraints on the development of market-oriented extractive reserves in Amazon rain forests. Pages 38-39 in D. C. Nepsted and S. Scwartzman, eds., Non-timber products from tropical forests - evaluation of a conservation and development strategy. Advances in Economic Botany (9), The New York Botanical Garden, New York.

Bunting, G. S. 1979. Sinopsis de las Araceae de Venezuela. Revista de la Facultad de Agronomía 10:139-290 (H. Jlexuosa).

- 1986. New taxa of Venezuelan Araceae. Phytologia 60:303-306. ( $H$. spruceana var. robusta, var. nov.; $H$. steyermarkii sp nov.; $H$. tenuispadix sp. nov.).

- 1988. New taxa of Venezuelan Araceae II. Phytologia 64:466. (H. flexuosa var. maguirei, var. nov.)

- 1996. Araceae. Pages 620-623 in J. A. Steyermark, P. E. Berry, and B. K. Holst, eds., Flora of the Venezuelan Guayana - Volume II. The Missouri Botanical Garden. Timber Press; Portland, Oregon. (H. Jexuosa, H. melinonii, H. spruceana, H. steyermarki, H. tenuispadix) 
Caufield, C. 1984. In the Rainforest: Report from a Strange. Beautiful. Imperiled World. University of Chicago Press. Chicago.

Clay, J. 1992. Some general principles and strategies for developing markets in North America and Europe for non-timber forest products: lessons from Cultural Survival Enterprises, 1989-1990. Pages 101-106 in D. C. Nepsted and S. Schwartzman, eds., Non-Timber Products from Tropical Forests Evaluation of a Conservation and Development Strategy. Advances in Economic Botany (9). The New York Botanical Garden. New York.

Cody, D. 1990. Feasibility Study and investment proposal for a Kufa/cane furniture plant in Georgetown, Guyana. South America. Unpublished. - 1996. Liana Cane Interiors. Ltd.: Business Plan-November 1996. Unpublished.

Colchester, M. 1991. Sacking Guyana. Multinational Monitor 8:8-14.

Croat, T. B. and N. Lambert. 1986. The Araceae of Venezuela. Aroideana 9:3-213. (H. melinonii and H. spruceana).

Croat, T. B. 1988. Ecology and life forms of Araceae. Aroideana 11:4-55.

Cunningham, A. B. and S. J. Milton. 1987. Effects of basket-weaving industry on Mokola palm and dye plants in Northwestem Botswana. Economic Botany 41:386-402.

Daniel, J. R. K. and B. A. Hons. 1984. Geomorphology of Guyana, an integrated study of natural environments. Occasional Paper No. 6. Department of Geography, University of Guyana. Georgetown. Guyana.

Daniels, J. D. and R. O. Lawton. 1991. Habitat and host preferences of Ficus crassiuscula, a neotropical strangling fig of the lower-montane rain forest. Journal of Ecology 79:129- 141.

Davis, E. W. and J. A. Yost. 1983. The ethnobotany of the Waorani of eastern Ecuador. Botanical Museum Leaflet, Harvard University 29:159-217.

Davis T. A. W. and P. W. Richards. 1933 and 1934. The vegetation of Moraballi Creek, British Guiana: an ecological study of limited area of tropical rain forest. Part I, II. Journal of Ecology 21:350-84; 22:106-55.

Dodson, C.H. and A. H. Gentry. 1978. Araceae. In Flora of the Rio Palenque Science Center. Los Ri'os Province, Ecuador. Selbeyana 4:56-57. (H. integerrima including illustration).

Dransfield, J., and N. Manokaran, eds. 1994. Page 21 in Plant resources of South-East Asia. No. 6: Rattans. Progor, Bogor, Indonesia.

Duke, J. 1992. Tropical botanical extractives. Pages 53-62 in M. Plotkin and L. Famolare, eds.. Sustainable harvesting and marketing of rain forest products. Island Press, Washington D. C.

Engler, A. 1878. Heteropsis Kunth. In A. and C. DeCandolle, ed., Monographie Phanerogamanum 2:98-100.

. 1905. Araceae-Pothoideae. Das Pflanzenreich IV 23B:50-53. 
- 1920. Araceae (Pars generalis et index familiae generalis). Das Pflanzenreich IV 23A:63.

Esau, K. 1966. Anatomy of seed plants. John Wiley \& Sons. New York.

Fanshawe, D. B. 1950. Forest products of British Guiana. Part II: minor forest products. Forestry Bulletin. British Guiana no. 2. (H. jenmanii and its local uses. mentions craftwork but not furniture).

Fanshawe, D. B. 1952. The vegetation of British Guyana. A preliminary review. Institute Paper no. 29. Imperial Forestry Institute: Oxford. UK.

FAO/UNESCO. 1988. Soil map of the world. FAO, Rome.

FAO. 1990. Forest resources assessment - tropical countries. FAO forestry paper, no. 112. FAO. Rome.

- 1995. Report of the international expert consultation on non-wood forest products. Yogyakarta. Indonesia. Non-wood forest products. No. 3. FAO, Rome.

Forte, J. 1996a. Amerindian/hinterland issues: Amerindians of Region 1. Pages 13-29 and 91-100 in About Guyanese Amerindians. Desktop published. Georgetown.

1996b. Barama River Caribs: between the rainforest and the world system. Pages 29-36 in

Thinking about Amerindians. Desktop published. Georgetown.

Frankie, J.V. 1994. Population dynamics of some tropical trees that yield non-timber forest products. Economic Botany 48:301 -309.

French, J. C. 1987a. Systematic survey of resin canals in roots of Araceae. Botanical Gazette. 148: 360371.

- 1987b. Systematic occurrence of a sclerotic hypodermis in roots of Araceae. American Journal of Botany, 74:891-903.

Funk, V. A. , C. Kelloff, and J. Bogan. 1993. Biodiversity of the Guianas - Plant Checklist. Smithsonian Institution. National Museum of Natural History, Washington. DC. (Guyana: $H$. flexuosa, $H$. longispathacea, $H$. melinonii, $H$. oblongata, $H$. spruceana, $H$. tenuispadix)

Gentry, A. 1993. A field guide to the families and genera of woody plants of northwestem South America (Columbia,Ecuador,Peru). Conservation International, Washington. D.C.

Gillin, J. 1936. The Barama River Caribs of British Guiana. Papers of the Peabody Museum of American Archaeology and Ethnology, Vol. XIV no.2. Harvard University, Cambridge. (Page 51: "Nibi, a slender bush rope, and mokru....provide the principal materials for basketry and plaiting. Nibi (Carludovica) is a vine about as large in diameter as a lead pencil. For use in plaiting it is first split in half; then the convex outer surface is split off each piece. producing a flat, ribbon-like strip, which is at the same time pliable and tough. This strip is then scraped with a knife.").

Glenboski, L. L. 1983. The ethnobotany of the Tukuna Indians, Amazonas, Colombia. Universidad Nacional de Colombia, Bogota. [Page 23: Heteropsis aff spruceana; Local spanish name: Tammische. Tamishi; Tukuna name: tun. Second growth forest (Glenboski 113, COL); "The stem (incorrect) is split lengthwise and used for broomstraw and for weaving baskets."] 
Godoy, R, R. Lubowski, and A. Markanandaya. 1993. A method for the economic valuation of nontimber forest products. Economic Botany 47:220-233

Godoy, R. and K. S. Bawa. 1993. The economic value and sustainable harest of plants and animals from the tropical forest: assumptions. hypotheses. and methods. Economic Botany 47:215-219.

Gómez-Pompa, A. and Burley, F.W. 1991. The management of natural tropical forests. Pages 3-18 in Gómez-Pompa. A.. Whitmore. T.C.. and Hadley; M.. eds.. Rain forest regeneration and management Parthenon Publishing Group and UNESCO/MAB. Paris.

Granville de, J. 1988. Phytogeographical characteristics of the Guianan forests. Taxon 37:578-594.

Grayum, M. H. 1990. Evolution and phylogeny of the Araceae. Annals of the Missouri Botanical Garden 77:628-697.

Grimes, A., S. Loomis, P. Jahnige, M. Burnham, K. Onthank, R. Alarcón, W. Palacios Cuenca, C. Cerón Martinez, D. Neill, M. Balick, B. Bennett, and R. Mendelsohn. 1994. Valuing the rain forest: the economic value of non-timber forest products in Ecuador. Ambio 23: $405+10$

Hall, P. and K. Bawa. 1993. Methods to assess the impact of extraction of non-timber forest products on plant populations. Economic Botany 47:234-247.

Haman M. and B. R. Wood. 1928. The forests of British Guiana. Tropical Woods 15:2-15.

Harling, G. 1958. Monograph of the Cyclanthaceae. Acta Horti Bergiani. 18:1-28.

Harper, J. L. 1977. Population biology of plants. Academic Press. London.

Hawkes, M. D. and J. R. D. Wall. 1993. The Commonwealth and Government of Guyana Rain Forest Programme. Phase I. Site Resource Survey, Main Report. Natural Resources Institute. Chatham. UK.

Hecht, S. and A. Cockburn. 1989. The Fate of The Forest. Verso, London.

Hegde, R., S. Suryaprakash, L. Achoth, and K. S. Bawa. 1996. Extraction of non-timber forest products in the forests of Biligiri Rangan Hills, India. 1. Contribution to rural income. Economic Botany 50:270-279.

Holdridge, L. R., W. C. Grenke, W. H. Hatheway, T. Liang, and J. A. Tosi. 1971. Forest Environments in Tropical Lifezones. Pergamon Press. New York.

Homma, A. K. O. 1992. Dynamics of extraction in Amazonia: a historical perspective. Pages 23-31 in D. C. Nepsted and S. Schwartzman, eds., Non-Timber Products from Tropical Forests - Evaluation of a Conservation and Development Strategy. Advances in Economic Botany (9). The New York Botanical Garden. New York.

Hosokowa, T. 1949. Studies on the life forms of vascular epiphytes and the spectrum of their life forms Japanese Journal of Botany 24:41-45.

Huber, O. 1995. Geographical and physical features. Pages 1-63 in J. A. Steyermark, P. E. Berry, and B. K. Holst, eds., Flora of the Venezuelan Guayana, Volume I. The Missouri Botanical Garden. Timber Press, Portland, Oregon. 
Huber, O., Gharbarran, G. and V. Funk. 1995. Vegetation map of Guyana - preliminany version. Center for the Study of Biological Diversity, University of Guyana. Georgetown. Guyana.

Humboldt, A. von., A. J. A. Bonpland, and K. S.Kunth. 1825. Nova General et Species Plantarum. 7:151.

Im Thurn, E. F. 1883. Among the Indians of Guiana. Kegan. Paul. Trench and Co., London.

Johnston, M. A. and Gillman, M. P. 1995. Species composition and stand structure in low-diversity forests. Biodiversity and Conservation 4:339-362.

Kelly, D. L. 1985. Epiphytes and climbers of a Jamaican rain forest: vertical distribution. life forms. and life histories. Journal of Biogeography 12:223-241.

Konstant, T. L., S. Sullivan, and A. B. Cunningham. 1995. The effect of utilization by people and livestock on Hyphaene petersiana (Arecaceae) basketry resources in the palm savannah of NorthCentral Namibia. Economic Botany 49:345-356.

Kunth, L. 1841. Enumeratio Plantarum 3:60.

La Rotta, C., P. Miraña, M. Miraña, B. Miraña, M. Miraña, and N. Yucuna. 1987. Estudio etnobotánico sobre las especies utilizadas por la comunidad indigena Miraña. Amazonas. Colombia. (Pages 257-260: Cite Heteropsis aff. oblongifolia, H. spruceana, and $H$. sp. with photo of $H$. aff. oblongifolia fertile voucher specimen (La Rotta 405); habitat listed as secondary, inundated forest).

Le Cointe, P. 1934. Page 126 in A Amazona Brasileira (III) Avores e plantas uteis (indigenas e acclimadas). Libraria classica, Belem, Brazil.

Macbride, J. F. 1936. Araccae. In Flora of Peru. Field Museum of Natural History, Botanical Series. 13:430-431. (H. jenmani, H. peruviana; cites Tessmann 4448: "believed by nearly all Loretians. even the most intelligent"; namely that the plant never blooms but is in fact a fungus that grows from the head of a black ant called "ishula". The fungus is long string-like plant known as "tamishi" (as also the Heteropsis itself)).

Madison, M. 1977a. A revision of Monstera (Araceae). Contributions from the Gray Herbarium 207: 1100.

- 1977b. Vascular epiphytes: their systematic occurrence and salient features. Selbeyana 2: 1-13

- 1979. Notes on some aroids along the Rio Negro, Brazil. Aroideana. 2:76. (H. spruceana cited on p. 76, including picture of author sitting on roots bundled for sale).

McDougall, G. J., I. M. Morrison, D. Stewart, J. D. B. Weyers, and J. R. Hillman. 1993. Plant fibres: botany, chemistry, and processing for industrial use. Journal of Science and Food Agriculture 62:1-20.

Medina, J. C. 1959. Page 214 in Plantas fibrosas do flora mundial. Instituto Agronomico Campinas, Sao Paulo, Brazil.

Milliken, W., R. P. Miller, S. R. Pollard, and E. V. Wandelli. 1992. Ethnobotany of the Waimini Atroari Indians of Brazil. Whitstable Litho, Kent, London. 
Myers, N. 1992. The primary source: tropical forests and our future updated for the 1990's. Nonon and Company, New York.

Nepsted, D. C. 1992. Conclusions and recommendations: the challenge of non-timber forest product extraction. Pages 143-146 in D. C. Nepsted and S. Schwartzman. eds. Non-timber products from tropical forests - evaluation of a conservation and development strategy. Advances In Economic Botany (9). The New York Botanical Garden. New York.

Nepsted, D. C. and S. Schwartzman. 1992. Introduction. Pages vii - viii in D. C. Nepsted and S. Schwartzman. eds., Non-timber products from tropical forests - evaluation of a conservation and development strategy. Advances In Economic Botany (9). The New York Botanical Garden. New York.

Oliver 1890. Hooker's Icon. Plate 20: t. 1949. (H. jenmanii)

Oliviera, J., S. Soares de Almeida, R Vilhena-Polyguara, and L. C. Batista-Lobato. 1991. Espécies vegetais produtoras de fibras utilizadas por communidades amazônicas. Boletim do Museu Paraense Emilio Goeldi. Série Botânica 7. Pages 398-399. (Uses of Heteropsis jenmanii (flexuosa) cited with photo).

Padoch, C. 1987. The importance and marketing of forest and fallow products in the Iquitos region. Pages 74-89 in W. M. Denevan and C. Padoch. eds., Swidden-fallow agroforestry in the Penuvian Amazon. The New York Botanical Garden. New York.

- 1992. Marketing of non-timber forest products in western Amazonia. Pages 43-50 in D. C. Nepsted and S. Scwartzman. eds., Non-timber products from tropical forests - evaluation of a conservation and development strategy. Advances In Economic Botany (9). The New York Botanical Garden, New York.

Padoch, C. and W. de Jong. 1989. Production and profits in agroforestry: an example from the Peruvian Amazon. Page 110 in J. O. Brower, ed., Fragile lands of Latin America: strategies for sustainable development. Westview Press, Boulder, Colorado.

Panayoutou, T. and P. S. Ashton. 1992a. Introduction and overview. Pages 3-15 in Not by timber alone - economics and ecology for sustaining tropical forests. Island Press, Washington, DC.

and __ 1992b. Non-timber forest products: a major component of forest total value. Pages 70-109 in Not by timber alone - economics and ecology for sustaining tropical forests. Island Press, Washington, DC.

Paz y Mino C., G., H. Balslev, and R. Valencia. 1995. Useful lianas of the Siona-Secoya Indians from Amazonian Ecuador. Economic Botany 49:269-275. Cite Heteropsis oblongifolia (Paz y Miño 81010) and include photograph of inflorescence, aerial roots, and basket. $H$. oblongifolia noted for high density in comparison with other climbing plants (10.2\%).

Peters, C. M., A. H. Gentry, and R. O. Mendelsohn. 1989. Valuation of an Amazonian rainforest. Nature 339:655-656.

Peters, C. M. and E. J. Hammond. 1990. Fruits from the flooded forests of Penuvian Amazonia: yield estimates for natural populations of three promising species. Pages 159 - 175 in G. Prance and M.J. Balick, eds., New directions in the study of plants and people. Advances in Economic Botany (8). New York Botanical Garden, New York. 
Peters, C. M. 1994. Sustainable harvest of non-timber plant resources in tropical moist forest: an ecological primer. Biodiversity Support Program, World Wildlife Fund. Washington. DC.

Plotkin, M. and L. Famolare. 1992. Sustainable harvest and marketing of rain forest products. Island Press. Washington, DC.

Prance, G. T., W. Balee, B. M. Boom and R. L. Carneiro. 1987. Quantitative ethnobotany and the case for conservation in Amazonia. Conservation Biology 1:269-310

Prance, G. 1989. Economic prospects from tropical rainforest ethnobotany. Pages 61-74 in J. Browder. ed.. Fragile lands of Latin America. Westview Press, Boulder.

Porsch, O. 1931. Araceae. I. Die Anatomie der Nahr- und Haft-wurlzeln von Philodendron selloum C. Koch. Ein Beitrag zur Biologie der Epiphyten. Denkschr. K. Akad. Wiss. Wien. Math.-Naturwiss. KI 79: $389-454$.

Putz, F. E. and N. M. Holbrook. 1986. Notes on the natural history of hemiepiphytes. Selbyana 9:61 $-69$.

Raju, M. V. S., T. A. Steeves, and R. T. Coupland. 1963. Developmental studies on Euphorbia escula L., morphology of the root system. Canadian Journal of Botany 41:579-589.

Ray, T. S. 1981. Growth and heterophylly in an herbaceous tropical vine, Syngonium (Araceae). $\mathrm{PhD}$ Thesis, Harvard University.

- 1987. Cyclic heterophylly in Syngonium (Araceae). American Journal of Botany 73:993-1001.

- 1988. Survey of shoot organization in the Araceae. American Journal of Botany 75:56-84.

. 1990a. Leaf types in the Araceae. American Journal of Botany 74:1359-1372.

. 1990b. Metamorphosis in the Araceae. American Journal of Botany 74:1599-1609.

189-203.

- 1992. Foraging behaviour in tropical herbaceous climbers (Araceae). Journal of Ecology 80:

Richards, P. W. 1952. The tropical rain forest. An ecological study. Cambridge University Press, London, UK.

Romero, G. 1993. Biologia del Mamure, Heteropsis spruceana Schott (Araceae). Informe Final. Presented to the Servicio Autonomode Desarrollo Ambiental del Estado Amazonas, Ministerio del Ambiente y de Recursos Naturales Renovables.

Ros-Tonen, M., W. Dijkman, and E. L. van Bueren. 1995. Page 21 in Commercial and sustainable extraction of non-timber forest products: towards a policy and management oriented strategy. The Tropenbos Foundation, Wageningen, Netherlands.

Salick, J. 1992. Amuesha forest use and management. Page 315 in C. Padoch and K.H. Redford, eds., Conservation of neotropical forests: working from traditional resource use. Columbia University Press, New York. ("Most important among these is tamshi (Heteropsis and Markgravia spp.), which is used 
to weave Amuesha baskets and mats and to construct everything from houses (nails are costly) to fish traps and baby baskets. This important forest product is becoming increasingly scarce near Amuesha settlements and must be collected as much as a day's walk away").

Schimper, A. F. W. 1884. Wissenschaftliche Original-Mittheilungen ueber Bau und Lebensweise der Epiphyten der Westindiens. Bot. Centralblatt. 17. (a pioneering account of morphology and ecology based on work in Dominica and Trinidad)

- 1888. Botanische Mittheilungen aus den Tropen. Heft 2. Die epiphytische Vegetation Amerikas Gustav Fisher. Jena.

. 1903. Tropical districts constantly moist. Pages 313-315 in P. Groom and I. B. Balfour. eds., Plant-geography upon a physiological basis. Clerendon Press, Oxford. (In German. translated by W.R. Fisher).

Schmink, M., K. H. Redford, and C. Padoch. 1992. Traditional people and the biosphere: framing the issues and defining the terms. Pages 11-13 in C. Padoch and K. H. Redford, eds., Conservation of neotropical forests: working from traditional resource use. Columbia University Press, New York.

Schmink, M. 1987. The rationality of tropical forest destruction in management of the forests of tropical America: prospects and technologies. U. S. Department of Agriculture, Washington, D.C.

Schott, H. W. 1853. Aroideae, 1:27, t.60. Vindobonae.

Schott, H. W. 1860. Prodomus Systematis Aroideanum. Vindobonae.

Shankar, U., K. S. Murali, R. U. Shaankar, K. N. Ganeshaiah, and K. S. Bawa. 1996. Extraction of non-timber forest products in the forests of Biligiri Rangan Hills, India. 3. Productivity, extraction. and prospects of sustainable harvest of Amla Phyllanthus emblica (Euphorbiaceae). Economic Botany 50:270-279.

Siebert, S.F. 1993. The abundance and site preferences of rattan (Calamus exilis and Calamus zollingeri) in two Indonesian national parks. Forest ecology and management, 59:105-113.

Simmonds, N. W. 1950. Notes on the biology of the Araceae of Trinidad. Journal of Ecology 38:277291.

Smith, A.C. 1939. Plantae Krukovianae. Journal of the Arnold Arboretum 20:289-290. (H. linearis, sp. nov.; H. macrophylla, sp. nov. A. C. Smith on $H$. macrophylla: "From H.Jenmani Oliv., apparently its closest ally, the new species differs by having its leaves less gradually narrowed at the extremities and lacking an acuminate tip, and by having a very regular collecting nerve extremely close to the leaf margin.)

Standley, P. C. 1937. Araceae. In Flora of Costa Rica. Field Museum of Natural History, Botanical Series 18:139. (H. oblongifolia)

ter Steege, H. and Cornellisen, J. H. C. 1989. Distribution and ecology of vascular epiphytes in lowland rainforest of Guyana. Biotropica 21:331-339.

ter Steege, H. et. al. 1996. Ecology and logging in a tropical rainforest in Guyana: with recommendations for forest management. The Tropenbos Foundation, Wageningen, The Netherlands. 
Strong, D. R. and T. S. Ray. 1975. Host tree location behavior of a tropical vine (Monstera gigant by skototropism. Science 190:804-806

Sullivan, S., T. L. Konstant and A. B. Cunningham. 1995. The impact of the utilization of palm products on the population structure of the vegetable ivory palm (Hyphaene petersiana. Arecaceac North-Central Namibia. Economic Botany 49:357-370.

Talley, S. M., W. M. Setzer, and B. R. Jackes. 1996. Host associations of two adventitious-rootclimbing vines in a North Queensland tropical rain forest. Biotropica 28:356-366.

Todzia, C. 1986. Growth habits, host tree species, and density of hemiepiphytes on Barro Colorado Island. Panama. Biotropica 18: 22-27.

Troll, W. 1943. Vergleichende Morphologie der hoheren Pflanzen. I. 3. Gebruder, Borntraeger. Berl

United Nations Conference on Environment and Development (UNCED). 1992. Country Report (Guyana). Government of Guyana (unpublished).

USDA. 1975. Soil Taxonomy Agricultural Handbook No. 436. Soil Conservation Service, US Department of Agriculture.

WCMC (World Conservation Monitoring Center). 1992. Higher plant diversity. Pages 64 - 87 in Groombridge. ed., Global biodiversity: status of the earth's living resources. Chapman and Hall. London

Went, F. A. F. C. 1895. Ueber Haft- und Naehrwurzeln bei Kletterpflanzen und Epiphyten. Ann. J. Bot. Buitenz. 12:1-72.

Wilder, G. J. 1986a. Anatomy of first-order roots in the Cyclanthaceae (Monocotyledonae). I. Epidermis, cortex, and pericycle. Canadian Journal of Botany 64:2622-2644.

- 1986b. Anatomy of first-order roots in the Cyclanthaceae (Monocotyledonae). II. Stele (excluding pericycle). Canadian Journal of Botany 64:2848-2864.

- 1992. Comparative morphology and anatomy of absorbing roots and anchoring roots in thre species of Cyclanthaceae (Monocotyledonae). Canadian Journal of Botany 70:38-48.

, and J. R. Johannsen. 1992. Comparative anatomy of absorbing roots and anchoring roots $i$ three species of Cyclanthaceae (Monocotyledonae). Canadian Journal of Botany 70:2384-2404.

Woodwell, G. M., ed. 1990. The Earth in Transition. Patterns and Processes of Biotic Impovisherme Cambridge University Press, Cambridge. 


\section{APPENDIX I.}

H. boliviana Rusby, Bull. N. Y. Bot. Gard. 6: 493.1910 (Bolivia).

H. ecuadoriensis Sodiro, Sert. Fl. Ecuad. Ser. 2: 81.1908 (Ecuador).

H. flexuosa (Kunth) Bunting, Revista Fac. Agron. Univ. Centr. Venezuela 10 :201. 1979.

Basonym: Pothos flexuosus Kunth (Venezuela); Synonym: Anthurium flexuosum Kunth

H. flexuosa (Kunth) Bunting var. maguirei Bunting, Phytologia 64: 466. 1988.

H. integerrima (Vell.) Strellfeld, Mus. Paran. 8:179. 1950

Basonym: Dracontium integerrimum Vell. (Brazil).

H. jenmanii Oliver, Hook. Icon. Pl.20: t. 1949. 1890. (Guyana)= Heteropsis fexuosa (Kunth) Bunting

H. linearis A. C. Smith, J. Arn. Arb. 20: 289. 1939 (Brazil).

H. longispathacea Engl., Das Pflanzenreich IV. 23B. Heft 27. Fam. 23b:53. 1905.

H. macrophylla A. C. Smith, J. Arn. Arb. 20: 290. 1939 (Brazil).

H. melinonii (Engl.) Fonker, Verhoef, and Fonker in Acta Bot. Neerl. 2:256. 1953. Basonym: Rhodospatha blanda ssp melinonii Engl. (French Guiana).

H. obliqua Miq. = Monstera obliqua Miq.

H. oblongifolia Kunth, Enum. PI. 3: 60. 1841 (Brazil).

H. ovata Miq. $=$ Monstera pertusa Schott

H. peruviana K. Krause, Notizbl. Bot. Gart. Berlin 9: 270. 1925 (Peru).

H. riedeliana Schott, Oestr. Bot. Zeitschr. 9:99. 1959 (Brazil).

H. rigidifolia Engl., Pflanzenreich Arac.-Poth. 51 (Brazil).

H. rimbachii K. Krause, Notizbl. Bot. Gart. Berlin 9: 269. 1925 (Ecuador).

H. salicifolia Kunth. Enum. PI. 3:60. 1841 (Brazil).

H. spruceana Schott, Aroideae 1: 27, t. 60.1853 (Brazil).

H. spruceana Schott, var. robusta Bunting, Phytologia 60: 303. 1986 (Venezuela).

H. steyermarkii Bunting, Phytologia 60: 305. 1986 (Venezuela).

H. surinamensis Miq. $=$ Monstera pertusa Schott

H. tenuispadix Bunting, Phytologia 60: 306.1986 (Venezuela). 


\section{APPENDIX II. VOUCHER SPECIMENS OBSERVED AT THE NEW YORK BOTANICAL GARDEN HERBARIUM.}

\section{H. ecuadoriensis Sodiro}

ECUADOR. Napo. Reserva el Chuscho; 1 km al oeste del Rio Payamino; NW del Coca. $280 \mathrm{~m}$; bosque primario y los alrededores; suelo rojo. Trepadora. hemi-epiphyta, el ultimo metro del tablo pendiente: hoja cartacea: inflorescencia pendiente; fruto anaranjado, lenticula. Mark Baker 6889. April 6. 1986.

\section{$\underline{\text { H. flexuosa (Kunth) Bunting var. flexuosa }}$}

BRAZIL. Maranhão. IEC - Comparative Ethnobotany of Tupi-Guarani Indian Project. Mun. Monçao. P.I. Guajá. Rio Turiaçu. Guajú Indians. $03^{\circ} 07^{\prime} \mathrm{S}, 46^{\circ} 05^{\prime} \mathrm{W}$. Terra firme forest. Vine. n.v. parakwã-cici. Tiestuff (stem), especially for house and grill. W. Balée 3504. June 29, 1987.

BRAZIL. Plants of the Brazilian Amazon. Território do Roraima. Indian trail from Surucucu to Uaicá between Maitá and Paramiteri village. $3^{\circ} 20^{\prime} \mathrm{N}, 63^{\circ} 24^{\prime} \mathrm{W}$. Forest on terra firme. Vine, sterile collection of material used by Uaicá Indian for making woven baskets and hammocks and for tying. Split into several strands and used to make hammocks and to tie the huts together. N.V.: Portuguese. "cipo titica"; Uaicá. "masicuk". G.T. Prance. W.C. Steward, F.P. Harner, J.F. Ramos, W.S. Pinheiro, and O.P. Monteiro 10660. February 21, 1971. (First det. incorrect: $H$. integerrima).

FRENCH GUIANA. Saül and vicinity. Route de Bélizon, 0-2 km S of Eaux Claires, $3^{\circ} 37^{\prime} \mathrm{N}, 53^{\circ} 12^{\prime} \mathrm{W}$, $230-200 \mathrm{~m}$. Non-flooded moist forest. Liana with super-axillary, spine-like projections from the stem. Mori, Gracie, and Snyder (coll. no. ?). September 22, 1994.

GUYANA. Flora of the Guianas Project. Rupununi District, Kuyuwini Landing and Kassikaityu River. Climbing: inflorescence yellow-orange, infructescence green to orange, $9 \times 5 \mathrm{~cm}$. Jensen-Jacobs 3077 . October 23, 1992.

PERU. Pasco, Oxapampa Province, Central Selva, Pacazu Valley. Forest above Iscozacin. Clay soils. "Vine with aerial roots". N.v.: "tamshi finito". Material for weaving (aerial roots) only used for very fine weaving because of small size of adventitious roots. Amuesha informant Esther Bautista. J. Salick 7707. August 29, 1986.

SURINAME. Sectie O.; Heuvel G. Stahel, no \#; February 6, 1942

SURINAME. Root often up to $20 \mathrm{~m}$ long. They are used for tying canoes, for making baskets, etc. Stahel 103. December 23, 1940.

VENEZUELA. Estado Bolivar, carretera El Dorado-La Gran Sabana, alrededores del km 87, en selva alta, y siempreverde, alt $200-400 \mathrm{~m}$. Climber in tree trunk. Stems the diameter of a pencil, leathery, adax. rich green with many apparent lateral nerves, abaxially yellow-green, and devoid of laterals superficially, midib sulcate adaxially, growing intermixed with 3098A (H. spruceana). G.S. Bunting 3098B. February $22,1968$.

VENEZUELA. Estado Bolivar, Chimanta-Massif. Rich rainforest on lower slopes of Albacapa, vicinity of Camp 1, along Rio Albacapa. 420 meters. N.v. "mamure". Commonly used for tying purposes. Steyermark 74792. March 30-31, 1953. 
VENEZUELA. Territorio Federal Amazonas: Cerro Duida. Forest at SE slopes along Caño Negro. Altitude $260 \mathrm{~m}$. Vine with strong climbing stem used in making basketry, furniture. and carrying cases for cargo (Guayare). Stem is cleft into three strands and these intertwined with one another. J.A. Steyermark 58059. August 28-29, 1944.

\section{H. flexuosa (Kunth) Bunting var. maguirei}

VENEZUELA. Territorio Federal Amazonas. A lo largo del Rio Zatuam margen izquierda, bajando desde el Cerro Arauicana. 125 metros. Climber $4 \mathrm{~m}$ up on tree trunk with long stems to ground again. $7 \mathrm{~mm}$ dia. green, very hard; lateral buds conic, $2 \mathrm{~mm}$ exserted: petiole deeply channeled w/ wings rolled in and overlapping: leaf blades very hard. brittle. margins strongly revolute, dark green glossy adaxially, the many nerves lightly sulcate. midrib sulcate-abaxially yellow-green. rib paler. I. Nerves dirty creamyellowish. J.A. Steyermark 102599. April 11-12, 1970.

\section{H. integerrima (Vell.) Strellfeld}

BRAZIL. Vicinity of Serra da Mao. Forest on terra firme. Vine, in $4 m$ tree. Fruit orange to red. G. T. Prance 12220. April 22, 1971.

\section{H. linearis A.C. Smith}

PERU. Loreto. Maynas. Iquitos. Puerto Almendras. Bosque primario, no inundable. Hemiepifito. estérile: de los raíces colgantes se confeccionan canastas, sesteria en general y artesania. R. Vasquez, N. Jaramico. 10547. Abril 1988.

\section{H. longispathacea Engl.}

BRAZIL. State of Maranhão. Basin of the Rio Turiaçu. Ka'por Indian Reserve. Moist terra firme forest. Liana $10 \mathrm{~m}$ tall; $\mathrm{C6}, 63$; Used to weave together Geonoma sp leaves for roofing. it is also commercialized. N.v.: "sypo te", "sypo xixik". W. L. Balée and A. Gely. April 12, 1985.

BOLIVIA. Cardenas-Tumapasa. $1500 \mathrm{~m}$. December 14, 1921.

SURINAME. Woods of Feticreek, Litanie. N.v.: "kamina" (N.E. Arow.), "mamidieme" (Waji). Geyskes 14. August $17,1939$.

\section{H. macrophylla A. C. Smith}

BRAZIL. Projeto Flora Amazonico, Plants of the Brazilian Amazon. State of Pará. BR 163, km 1131, vicinity of Igarape. Natal. forest on terra firme. Vine; spathe yellow; spadix white. G.T. Prance et. al. P 25429. November 15, 1977.

\section{H. oblongifolia Kunth}

BRAZIL. Plants of Acre: Plant use by women in a rubber-tapping community. Xapuri, low lands and terra firme in primary forest. Vine used in basketry. N.v.: "titica". K. Kainer \#42. September 13, 1989

BOLIVIA. Departamento Pando. Sperling 6409. July 30, 1982.

PERU. Plants of Peru: New York Botanical Garden\ National Cancer Institute. Depto. Loreto, Prov. Maynas, Rio Nanay, Puerto Almendras, near Iquitos. Moist forest, flat terrain. N.v.: "tamishi" for dropsy. Liquid concoction of $0.5 \mathrm{~kg}$ boiled plant; drink 3 cups per day. Chota 14. March 3, 1989. 
PERU. State of Pasco: Oxapampa Prov: Central selva. Palcazu valley: Iscozacin Bosque Resena. above Pepp. Proj. Camp. Forest on upper terrace. clay soils. N.r.: "pocenpàr". Bathing in infusion promotes tranquil sleep and helps one forget one's troubles. Salick 6120. May 29. 1984.

PERU. Enrique Pedro: Menstruating women drink tea. Salick 7176a. July 2. 1984

VENEZUELA. Territorio Federal Amazonas. Rio Orinoco. cerca márgins del rio. Altura $365 \mathrm{~m}$. Bejuco. N.x.: "monat-ta" (= para hacer) and "mamure". Croxent 275. January 9. 1952.

\section{$\underline{\text { H. rigidifolia Kunth }}$}

BRAZIL. New York Botanical Garden with Centro de Pesquisas do Cacau. Bahia. Bahia Mun. Unà Resena. Biológica do Mico-Ilao (IBAMA). Atlantic coastal forest on hilltop. Epiphytic vine. W.W. Thomas et. al. 9447.

BRAZIL. Paraná. Tacarchỵ. Dusén 11392. March 24, 1911.

\section{H. rimbachii K. Krause}

ECUADOR. Gill-Merrill Ecuador Expedition. Oriente: Napo-Pastaza. Basin of Rio Pastaza. PacalucuSarayacu region. Rio Bobonaza and adj. tributaries. 1000m. R.C. Gill \# 64. August-October 1938.

\section{H. peruviana K. Krause}

PERU. Dept. Ayacucho. Rio Apurimac Valley near Kimpitiriki. Alt. $400 \mathrm{~m}$. Dense forest. Killip and A.C. Smith 22984. 1929.

\section{H. salicifolia Kunth.}

BRAZIL. Projeto Flora Amazônico. Plants of the Brazilian Amazon. Território do Roraima. Surucucu. $3^{\circ}$ $20^{\prime} \mathrm{N}, 63^{\circ} 24^{\prime} \mathrm{W}$. Stem used in basket work. G.T Prance et. al. 10660. 1971.

\section{H. spruceana Schott}

BRAZIL. Amazonas. Serra Aracá. southern massif. W-facing talus slope. Black water, seasonally inundated forest on sandy soils. Scrambling vine: flowering spadix erect. cream-white. J. Pipoly et. al. 6711. February 27, 1984.

VENEZUELA. Territorio Federal Amazonas. Depto. Atabapo. Cerro Huachamacari. E slope. Forested. Epiphyte; fruit green becoming orarge. Liesner 25792. November 4, 1988.

VENEZUELA. Bolivar. Carretera El Dorado-La Gran Sabana. alrededores del km 87 en selva alta y siempreverde. Alt. $200-400 \mathrm{~m}$. Aerial roots very tough and used extensively as tie material and for basketmaking, furniture construction. etc. N.v. "alambrito". Bunting 3098a. February 22, 1968.

\section{H. spruceana Schott, var. robusta Bunting}

GUYANA. New York Botanical Garden - Guiana Explorations. Bank of Haieka River, 2 km E of Chinoweing Village. $740 \mathrm{~m}$. Epiphyte; lvs drk green, coriaceous; spathe white, deciduous; spadix creme. S Tillett, C Tillett, R. Boyan. August 22, 1960. 
VENEZUElA. Cerro de la Neblina Expedition. Amazonas. Dpto. Rio Negro. Neblina basecamp. Rio Mawarinuma. $140 \mathrm{~m}$. Terra firme forest. along trail near river. Boom and Wetzman 5916. February 20. 1985.

\section{H. stejermarkii Bunting}

VENEZUELA. Territorio Federal Amazonas. Depto. Atabapo. In saddle between Duida and Marahuaca near base of Duida. Medium height forest. $1000 \mathrm{~m}$. Epiphyte. Leaves glacous below; spathe green-yellow: spadix green. Liesner 25500 . October 27, 1988.

VENEZUELA. Territorio Federal Amazonas. Depto. Casiquiare. Alrededores de Yavita (Rio Temi) a la izquierda de la via saliendo de Yavita rumbo a Pimichi en bosque inundado. 125-140 m. Common climber on tree trunks. Bunting 3907. July 6-19, 1969.

\section{H. tenuispadix Bunting}

VENEZUELA. New York Botanical Garden 1959 Venezuela Expedition. Territorio Federal Amazonas Caño Masagua. right bank of Rio Orinoco, $1 \mathrm{~km}$ above mouth of Rio Atabapo. $125 \mathrm{~m}$ elev. Vine in tree tops; fruit green; "mamure", Aerial roots are most used to tie material in Amazonas. Locally frequent. Wurdack and Adderly 43796. August 8, 1959.

\section{cf. H. tenuispadix}

BRAZIL. Programa Flora. Instit. Nac. de Pesquisas da Amazonia. Plants of the Brazilian Amazon.

Estrada Manaus. Caracarai, km 329, N of Waimiri-Atroari Indian Reserve. Primary forest on terra firme. sandy soil. Vine, infl green. W.C. Steward \#57. November 17, 1977. 
APPENDLX III. FIELD IDENTIFICATION AND NUMBER OF $\boldsymbol{H}$. FLEXUOSA HOST TREES

\begin{tabular}{|c|c|c|c|c|}
\hline Scientific Name & Common name & Language & Family & $\begin{array}{l}\text { no host } \\
\text { trees }\end{array}$ \\
\hline Aniba or Ocotea sp. & Sitverballi & Creole & LAURACEAE & 3 \\
\hline Aniba sp. (probably Aniba hypoglauca Sandw.) & $\begin{array}{l}\text { Yellow } \\
\text { SIlverballi }\end{array}$ & Creole & LAURACEAE & 3 \\
\hline $\begin{array}{l}\text { Aspidosperma excelsum Benth. or A. } \\
\text { oblongum A.DC. }\end{array}$ & Yarola & Creole & APOCYNACEAE & 22 \\
\hline Brosimum sp. & Leopard Wood & Creole & MORACEAE & 2 \\
\hline Carapa guianensis Aublet & Crabwood & Creole & MELIACEAE & 10 \\
\hline Caryocar sp. & Sowrie & Creole & CARYOCARACEAE & 1 \\
\hline Cassia sp. & Warua & Arawak & CAESALPINIOIDEAE & 3 \\
\hline Catostemma fragrans Benth. & Baromalli & Arawak & BOMBACACEAE & 29 \\
\hline Centrolobium paraense Tul. & Redwood & Creole & LEGUMINOSAE & 1 \\
\hline $\begin{array}{l}\text { Chlorocardium rodiel (Schomb.) } \\
\text { Rohwer, Richter and v.d. Werff }\end{array}$ & Greenheart & Creole & LAURACEAE & 13 \\
\hline $\begin{array}{l}\text { Clathrotropis brachypetala (Tul.) } \\
\text { Kleinhoonte }\end{array}$ & Aromata & Arawak & PAPILIONOIDEAE & 28 \\
\hline Dead Snag & Dead & Na & DEAD & 7 \\
\hline Duguetia sp. & Yami-Yarri & Creole & ANNONACEAE & 1 \\
\hline Eperua spp. & Wallaba & Creole & CAESALPINIOIDEAE & 23 \\
\hline Eschweilera sp. (mostly E. sagotiana Miers) & Kakralli & Arawak & LAURACEAE & 126 \\
\hline Eugenia sp. & Wild Cherry & Creole & MYRTACEAE & 1 \\
\hline Euterpe aleraceae Mart. & Manicole & Creole & PALMAE & 1 \\
\hline Ficus sp. & Fig & Creole & MORACEAE & 1 \\
\hline Goupia glabra Aublet & Kabukalli & Arawak & CELASTRACEAE & 6 \\
\hline Guatteria sp. & $\begin{array}{l}\text { Yarri-Yarri, } \\
\text { black }\end{array}$ & Creote & ANNONACEAE & 4 \\
\hline Inga sp. & Waikj & Creole & MIMOSOIDEAE & 1 \\
\hline Iryanthera sp. & Kirikaua & Arawak & MYRISTICAEAE spp. & 1 \\
\hline Jacaranda sp. & Mari-mari, Pooti & Creote & BIGNONIACEAE & 3 \\
\hline Jacaranda sp. & Futee & Arawak & BIGNONIACEAE & 1 \\
\hline Jessenia/Oenocarpus sp. & Turu & Arawak & ARECACEAE & 1 \\
\hline Lecythis sp. & Monkey Pot & Creole & LECYTHIDACEAE & 8 \\
\hline Licania sp. E. sagotiana (Miers) & Counta & Creole & CHRYSOBALANACEAE & 64 \\
\hline Licania sp. & Kairiballi & Arawak & CHRYSOBALANACEAE & 17 \\
\hline $\begin{array}{l}\text { Manikara bidentata (A.DC.) Chev. ssp } \\
\text { bidentata }\end{array}$ & Balata & Patamona & SAPOTACEAE & 3 \\
\hline Mora excelsa Benth. & Mora & Creole & CAESALPINIOIDEAE & 141 \\
\hline Mora gonggnipi Sandw. & Morabukea & Creole & CAESALPINIOIDEAE & 1 \\
\hline Myrciaria sp. & Wild Guava & Creole & MYRTACEAE & 3 \\
\hline n/a & Assissi & & & 7 \\
\hline Na & Casiwood & & & 2 \\
\hline na & Glamour Cherry & Creole & MYRTACEAE & 1 \\
\hline na & Woodskin balli & Creole & & 6 \\
\hline Ocotea sp. & Karotee & Arawak & LAURACEAE & 1 \\
\hline Parinari sp. & Buhuda & Creole & CHRYSOBALANACEAE & 32 \\
\hline Pentactethra macroloba (Willd) Kuntze & Trysil & Creole & LEGUMINOSAE & 4 \\
\hline Pithecellobium sp. & Soapwood & Creole & LEGUMINOSAE & 1 \\
\hline Pouteria sp. & Asepoko & Arawak & SAPOTACEAE & 16 \\
\hline
\end{tabular}


Protium sp.

Protium sp.

Kurokai

Arawak

BURSERACEAE

10

Sapium sp.

Holo

Milkwood BURSERACEAE

Sterculia pruriens (Aublet) Schumann

Maho

Creole

SAPOTACEAE

1

Swartzia sp.

Wamara

Arawak

STERCULIACEAE

Tovomita sp.

Wild Mangrove

Arawak

LEGUMINOSAE

106

Unknown

Unknown

na

GUTTIFERAE

Unknown

Total

1026

Taxa colonized in 10 or more instances are in bold print. 